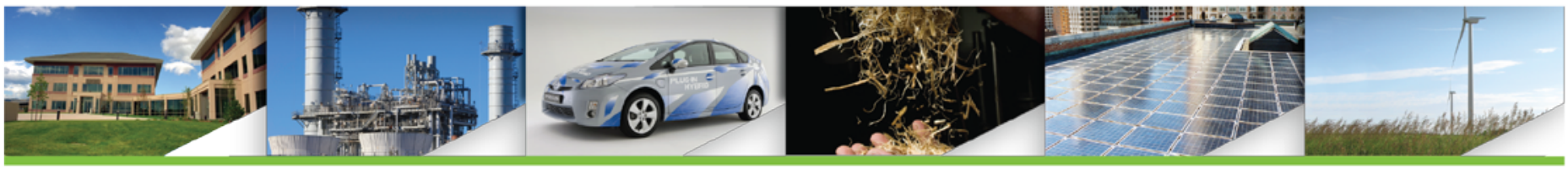

\title{
Concentrating Solar Power and Water Issues in the U.S. Southwest
}

Nathan Bracken

Western States Water Council

Jordan Macknick and Angelica Tovar-Hastings National Renewable Energy Laboratory

Paul Komor

University of Colorado-Boulder

Margot Gerritsen and Shweta Mehta Stanford University

The Joint Institute for Strategic Energy Analysis is operated by the Alliance for Sustainable Energy, LLC, on behalf of the U.S. Department of Energy's National Renewable Energy Laboratory, the University of Colorado-Boulder, the Colorado School of Mines, the Colorado State University, the Massachusetts Institute of Technology, and Stanford University.

Technical Report

NREL/TP-6A50-61376

March 2015

Contract No. DE-AC36-08GO28308

MNREL O Coloradoschoolormunes 


\section{Concentrating Solar Power and Water Issues in the U.S. Southwest}

Nathan Bracken

Western States Water Council

Jordan Macknick and Angelica Tovar-Hastings National Renewable Energy Laboratory

Paul Komor

University of Colorado-Boulder

Margot Gerritsen and Shweta Mehta

Stanford University

Prepared under Task No. 6A50.1010

The Joint Institute for Strategic Energy Analysis is operated by the Alliance for Sustainable Energy, LLC, on behalf of the U.S. Department of Energy's National Renewable Energy Laboratory, the University of Colorado-Boulder, the Colorado School of Mines, the Colorado State University, the Massachusetts Institute of Technology, and Stanford University.

JISEA $^{\circledR}$ and all JISEA-based marks are trademarks or registered trademarks of the Alliance for Sustainable Energy, LLC.

The Joint Institute for Strategic Energy Analysis 15013 Denver West Parkway Golden, CO 80401 303-275-3000 • www.jisea.org
Technical Report

NREL/TP-6A50-61376

March 2015

Contract No. DE-AC36-08GO28308 


\section{NOTICE}

This report was prepared as an account of work sponsored by an agency of the United States government. Neither the United States government nor any agency thereof, nor any of their employees, makes any warranty, express or implied, or assumes any legal liability or responsibility for the accuracy, completeness, or usefulness of any information, apparatus, product, or process disclosed, or represents that its use would not infringe privately owned rights. Reference herein to any specific commercial product, process, or service by trade name, trademark, manufacturer, or otherwise does not necessarily constitute or imply its endorsement, recommendation, or favoring by the United States government or any agency thereof. The views and opinions of authors expressed herein do not necessarily state or reflect those of the United States government or any agency thereof.

Available electronically at http://www.osti.gov/scitech

Available for a processing fee to U.S. Department of Energy and its contractors, in paper, from:

U.S. Department of Energy

Office of Scientific and Technical Information

P.O. Box 62

Oak Ridge, TN 37831-0062

phone: 865.576.8401

fax: 865.576 .5728

email: mailto:reports@adonis.osti.gov

Available for sale to the public, in paper, from:

U.S. Department of Commerce

National Technical Information Service

5285 Port Royal Road

Springfield, VA 22161

phone: 800.553 .6847

fax: 703.605.6900

email: orders@ntis.fedworld.gov

online ordering: http://www.ntis.gov/help/ordermethods.aspx

Cover Photos: (left to right) PIX 04135, iStock 22779761, PIX 16933, PIX 15648, PIX 08466, PIX 21205

NREL prints on paper that contains recycled content. 


\section{Acknowledgments}

The authors would like to thank the following for their review, input, and contributions to this report: James Bartride and Roger Johnson of the California Energy Commission; Stacey Crowley of the Nevada State Office of Energy; Christopher Harris of the Colorado River Board of California; Tom Iseman of the U.S. Department of the Interior; Jeanine Jones of the California Department of Water Resources; Jason King of the Nevada Division of Water Resources; Kristin Mayes of the University of Arizona's Sandra Day O'Connor College of Law; Michael Lacey of the Arizona Department of Water Resources; Brad Nickell of Electrical Marketing Solutions; and Dwane Young of the Environmental Protection Agency. The authors would also like to thank Karin Haas, Mary Lukkonen, Craig Turchi, Laura Vimmerstedt of the National Renewable Energy Laboratory as well as Tony Willardson and Sara Larsen of the Western States Water Council and Patricia Statwick of the Joint Institute for Strategic Energy Analysis for their support and insightful comments. The authors would also express their appreciation to the Joint Institute for Strategic Energy Analysis for supporting this work.

The views expressed herein are those of the authors alone and do not necessarily reflect their respective institutions or the views of any states that are members of the Western Governors' Association or Western States Water Council. Any errors are the sole responsibility of the authors. 


\section{List of Acronyms}

ACC

ADEQ

ADWR

AFC

AMA

AOI

ARRA

AZPDES

BCPA

BLM

BTU

BWPC

CAP

CCS

CEC

CEQA

COEC

CPV

CRIT

CSI

CSP

CURE

CWA

DNI

DOE

DR

EA

EIA

EIR

EIS

EPA

EPAct

ESA

FLPMA

GFR

GIU

GMA

GPM

GSF

GW

HVS

IEA

IGCC

IGFR
Arizona Corporation Commission

Arizona Department of Environmental Quality

Arizona Department of Water Resources

application for certification (California)

Active Management Area (Arizona)

Area of hydrologic impact (Arizona)

American Reinvestment and Recovery Act

Arizona Pollutant Discharge Elimination System

Boulder Canyon Project Act

U.S. Bureau of Land Management

British thermal unit

Bureau of Water Pollution Control (Nevada)

Central Arizona Project

Carbon Capture and Storage

California Energy Commission

California Environmental Quality Act

Certificate of Environmental Compatibility

concentrating photovoltaic

Colorado River Indian Tribes

California Solar Initiative

concentrating solar power

California Unions for Reliable Energy

Clean Water Act

direct normal irradiance

U.S. Department of Energy

Demand Response

Environmental Assessment

U.S. Environmental Information Administration

environmental impact report (California)

environmental impact statement

U.S. Environmental Protection Agency

Energy Policy Act

Endangered Species Act

Federal Land Policy Management Act

grandfathered groundwater rights (Arizona)

general industrial use (Arizona)

Groundwater Management Act (Arizona)

gallons per minute

groundwater savings facility (Arizona)

gigawatt

Hualapai Valley Solar LLC

International Energy Agency

Integrated Gasification Combined Cycle

irrigation grandfathered groundwater rights

(Arizona) 


\begin{tabular}{|c|c|}
\hline INA & Irrigation Non-Expansion Area (Arizona) \\
\hline ITC & investment tax credit \\
\hline $\mathrm{kW}$ & kilowatt \\
\hline $\mathrm{kWh}$ & kilowatt-hour \\
\hline LCOE & levelized cost of energy \\
\hline MOU & memorandum of understanding \\
\hline MW & megawatt \\
\hline MWh & megawatt-hour \\
\hline NDEP & Nevada Division of Environmental Protection \\
\hline NEPA & National Environmental Policy Act \\
\hline NOI & notice of intent to drill (Arizona) \\
\hline NPDES & National Pollutant Discharge Elimination System \\
\hline NREL & National Renewable Energy Laboratory \\
\hline PEC & Portfolio Energy Credit (Nevada) \\
\hline PEIS & Programmatic Environmental Impact Statement \\
\hline PUC & Public Utilities Commission of Nevada \\
\hline PV & photovoltaic \\
\hline RAM & Renewable Auction Mechanism (California) \\
\hline REAT & Renewable Energy Action Team (California) \\
\hline RPS & renewable portfolio standard \\
\hline RTEP & Regional Transmission Expansion Planning Project \\
\hline RWQCB & Regional Water Quality Control Board (California) \\
\hline SA & staff assessment (California) \\
\hline SEIA & Solar Energy Industries Association \\
\hline SEGS & Solar Energy Generating System \\
\hline SWRCB & State Water Resources Control Board (California) \\
\hline TEP & Tucson Electric Power \\
\hline TES & Thermal Electric Storage \\
\hline TWh & terawatt-hour \\
\hline USF & underground storage facility (Arizona) \\
\hline USGS & U.S. Geological Survey \\
\hline WDR & waste discharge requirements (California) \\
\hline WECC & Western Electricity Coordinating Council \\
\hline WGA & Western Governors’ Association \\
\hline WRR & water recycling requirements (California) \\
\hline WSWC & Western States Water Council \\
\hline
\end{tabular}




\section{Executive Summary}

Concentrating solar power (CSP) systems utilize the sun's energy to create heat that is used to generate electrical power. CSP systems in the United States are installed primarily in the Southwest, with $92 \%$ of plants that are operational, under construction, or under development located in three western states - Arizona, California, and Nevada. This report provides an overview of CSP development in these states, or the "Southwest" for the purposes of this discussion, with a particular focus on the water supply issues associated with CSP.

The Western Governors' Association (WGA) commissioned staff from the Western States Water Council (WSWC) to collaborate with staff from the National Renewable Energy Laboratory (NREL) to prepare this report. The WGA has long supported the effective management of the West's water resources, as well as the development of a clean, diverse, reliable, and affordable energy supply consisting of traditional and renewable energy resources. This report is specifically intended to help inform these goals, especially as WGA continues to underwrite a Regional Transmission Expansion Planning project, undertaken by the WSWC and the Western Electricity Coordinating Council (WECC), to better understand energy development within the existing and future water resource constraints of the West.

This report builds upon earlier research conducted by NREL, the University of ColoradoBoulder, and Stanford University that was supported through the Joint Institute for Strategic Energy Analysis (JISEA) and presents information gathered through extensive research and literature reviews, as well as interviews and outreach with state water administrators and energy regulators, WECC and other experts familiar with CSP development in the Southwest.

To discuss CSP development in the Southwest, this report: (1) provides an overview of CSP technology; (2) describes the status of CSP development in the United States and the Southwest; (3) summarizes the state water rights permitting and CSP facility permitting processes in the Southwest; (4) discusses water supply and other related issues associated with CSP development; (5) studies three CSP projects; and (6) sets forth observations regarding CSP development in the Southwest and associated water supply issues. Key observations that emerged from this effort include:

- Scope of Current CSP Development: As of August 2014, the CSP projects outlook across the United States consists of 39 projects with a total potential operating capacity of $5,101 \mathrm{MW}$, including 24 operational CSP plants (1,495 MW), 4 plants under construction (366 MW), and 11 projects proposed or otherwise under development (3,240 MW). All but five of these projects are located in Arizona, California, and Nevada. Although CSP has grown in recent years, it provides a relatively minor amount of the nation's electricity generating and capacity portfolio $-0.03 \%$ and $0.05 \%$, respectively.

- Public vs. Private Land: The Bureau of Land Management (BLM) is undertaking a number of efforts to facilitate solar energy development, including CSP and solar photovoltaic (PV), on over 19 million acres of federal lands in Arizona, California, Colorado, Nevada, New Mexico, and Utah, which could potentially result in almost 32 GW of installed utility-scale solar project capacity on BLM and other federal lands in these states by 2030. However, some developers view the process used to approve CSP plants on federal lands as overly burdensome or time consuming and have avoided siting 
projects on federal land. Nevertheless, as is the case in California, many of the most suitable locations for CSP development could be located on federal land, and private land might simply be unavailable.

- Water Use: Every CSP plant uses some amount of water. Although wet-cooled CSP plants generally consume more water than many other forms of energy, they consume one-third of the amount that alfalfa and cotton consume per acre and about one-half of the water a golf course consumes per acre. Dry-cooled CSP plants use relatively little water and consume less water than wet-cooled nuclear, coal, and natural gas facilities. Dry-cooled CSP plants also have a water impact similar to natural gas facilities employing dry cooling. Current estimates indicate that operational CSP plants use at least 620 acre-feet per year. By 2030, the BLM estimates that water demand for wet-cooled and dry-cooled solar projects (including CSP and PV) in the Southwest could total over 221,000 acre-feet and almost 18,000 acre-feet of water per year, respectively.

- Cost of CSP: CSP capital costs are generally higher than most other traditional and renewable energy technologies, with the capital costs of CSP with storage totaling $\$ 7,100 / \mathrm{kW}$ and its levelized cost of energy (LCOE) equaling \$170-\$290/MWh. In comparison, the capital costs of coal, gas, and PV plants are $\$ 3,600, \$ 1,100$, and $\$ 2,900$ per $\mathrm{kW}$, respectively. The LCOEs for these technologies are $\$ 60-\$ 90 / \mathrm{MWh}, \$ 50$ $\$ 60 / \mathrm{MWh}$, and \$100-\$170/MWh, respectively. However, through the use of thermal energy storage CSP can provide important grid services that aren't captured by the LCOE metric through replacing low efficiency fossil generators (and expensive fuel costs) during peak summer load.

- Competition from Other Energy Technologies: Given CSP's higher capital costs, energy developers are turning increasingly to $\mathrm{PV}$, which has seen significant price declines since 2009. Developers have converted a number of previously proposed CSP plants to PV. Given this trend, the rate at which CSP will continue to grow remains uncertain. It is also worth noting that PV systems do not require water for cooling purposes because they turn the sun's energy directly into electricity rather than heat and therefore require considerably less water than CSP. PV plants utilize water for panel washing, dust suppression, and potable uses.

- Permitting: States are primarily responsible for administering water rights within their borders. In general, CSP plants must obtain water right permits from the applicable state water management agency, but plants located in California or in Arizona outside of the state's Active Management Areas (AMAs) generally do not require state-issued permits. However, most CSP plants must obtain approval from a state utility commission or energy planning agency. These agencies can play a critical role in evaluating a project's proposed water use and some have the authority to reject or condition a project's approval based on its water use.

- Groundwater: Most CSP plants are located or are being proposed in remote desert areas that are far from population centers, typically leaving groundwater as the only available or most feasible water source. In Arizona, a number of plants are being sited outside of the state's AMAs and do not require state-issued water right permits. Similarly, most CSP plants in California rely on groundwater and also do not require state-issued water right permits. 
- Wet Cooling, as Compared to Dry and Hybrid Cooling: There is an increasing trend that favors dry-cooled and hybrid CSP plants over wet-cooled plants, particularly in California and Nevada. For example, of the 24 CSP plants that are operational in the Southwest, 17 are wet-cooled. In contrast, of the 15 CSP projects that are under construction or development in the region, at least 9 will be dry-cooled, hybrid-cooled, or use reclaimed water.

- Location: Where a project is located has a significant impact on its feasibility and ability to secure the necessary regulatory approvals. In general, projects that are sited on disturbed sites appear to generate relatively less opposition to their potential environmental impacts. Projects located on previously irrigated land that use less water than the prior use also appear to face less opposition. 


\section{Table of Contents}

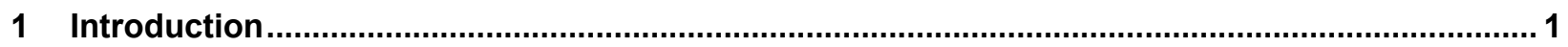

1.1 The Energy and Water Policies of the Western Governors' Association...................................... 1

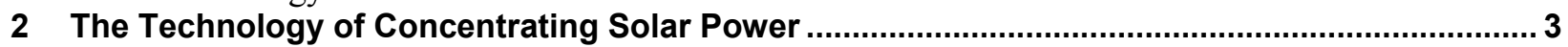

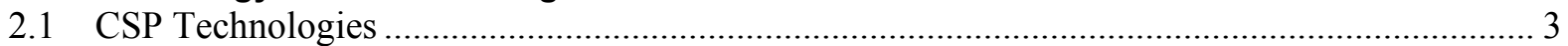

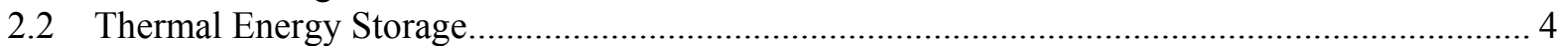

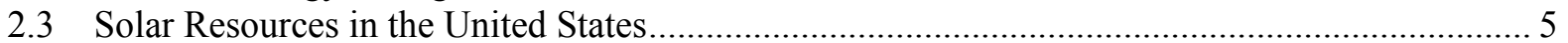

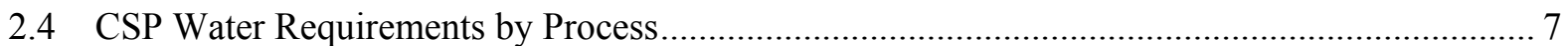

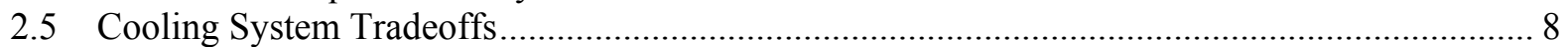

2.6 Comparison of CSP Water Requirements With Other Electricity Generating Technologies ....... 9

2.7 Comparison of CSP Water Requirements With Other Land Uses ............................................ 10

3 CSP Development in the United States and Southwest ..................................................... 12

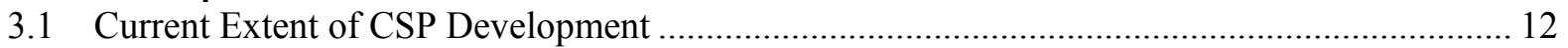

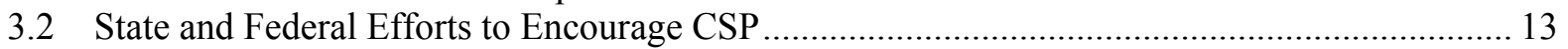

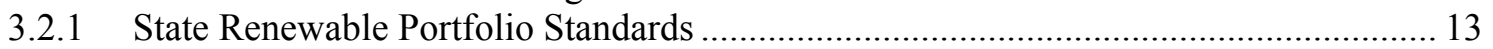

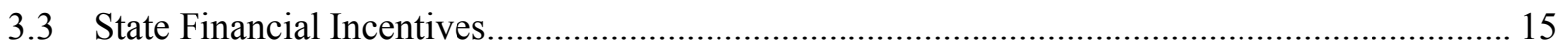

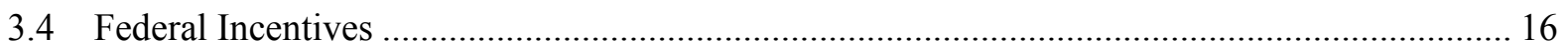

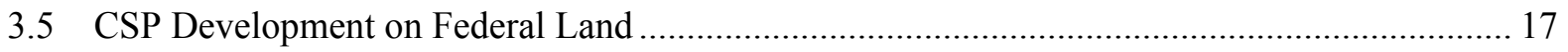

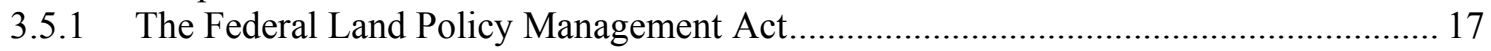

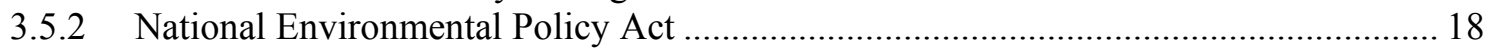

3.5.3 BLM's "Fast-Track” Approval Process ....................................................................... 19

3.5.4 Federal Solar "Roadmap" for Utility-Scale Solar Development on Federal Lands ....... 19

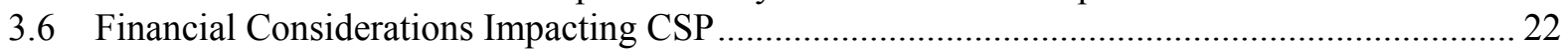

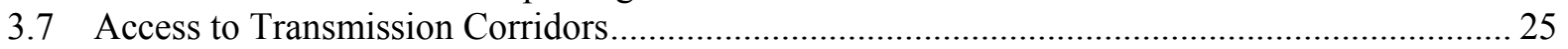

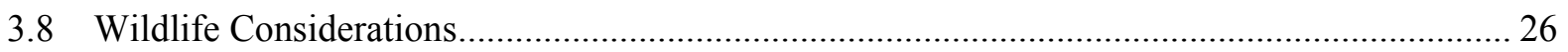

3.9 Impacts to Native American Cultural Resources ................................................................... 27

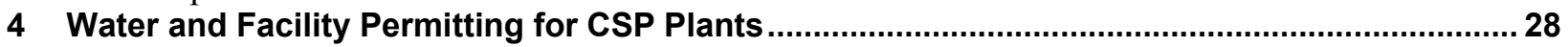

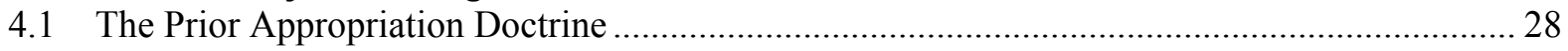

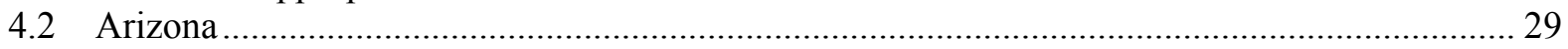

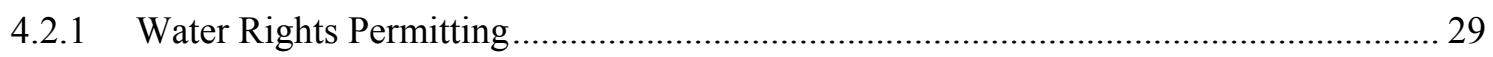

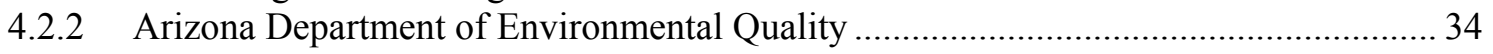

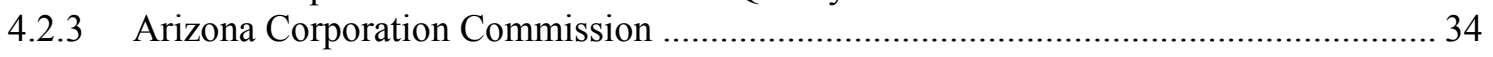

4.2.4 State Actions Regarding the Use of Water for Power Plant Cooling ............................ 35

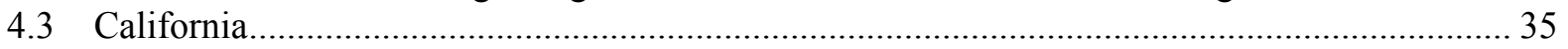

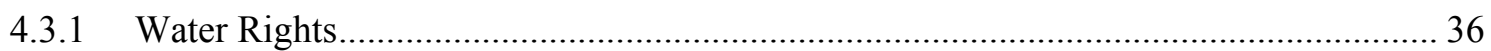

4.3.2 SWRCB and Regional Water Boards - Water Quality ….............................................. 38

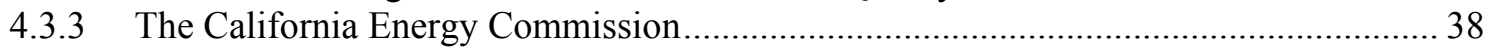

4.3.4 State Actions Regarding the Use of Water for Power Plant Cooling ............................ 39

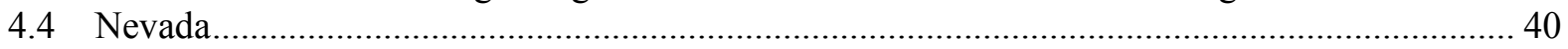

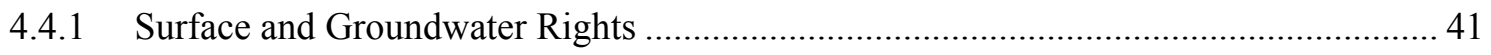

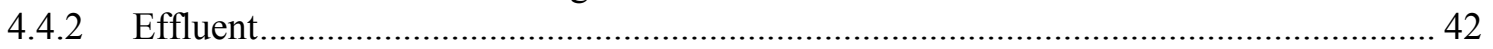

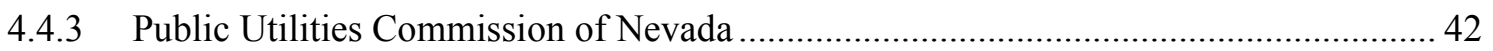

4.4.4 Nevada Division of Environmental Protection ........................................................... 42

4.4.5 State Actions Regarding the Use of Water for Power Plant Cooling .............................. 42

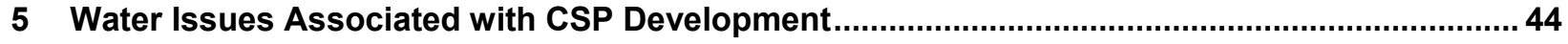

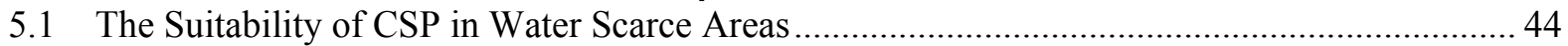

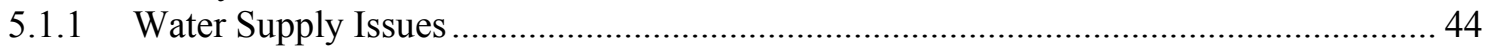

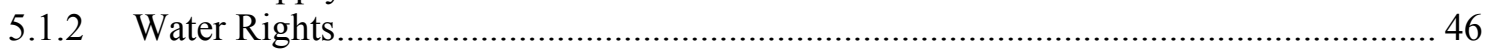

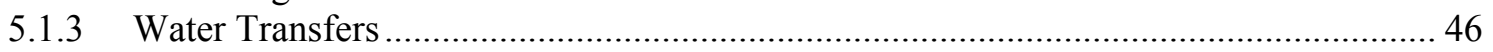

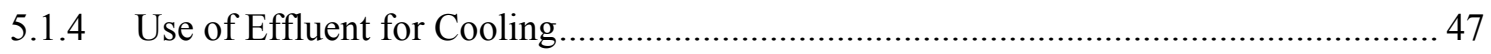




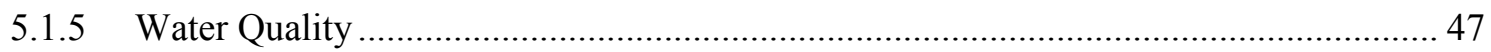

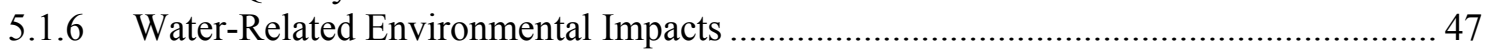

5.1.7 Public Opinion and Perception................................................................................... 48

5.2 State Actions Expressing a Preference for Alternative Cooling Technologies .......................... 48

5.3 Notable Federal Water-Related Laws and Policies Regarding CSP ....................................... 48

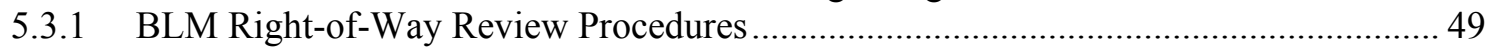

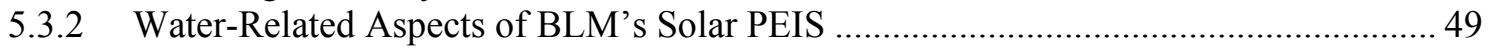

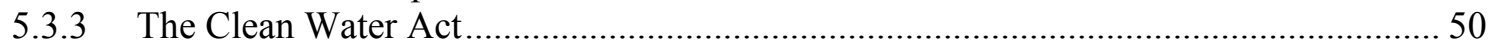

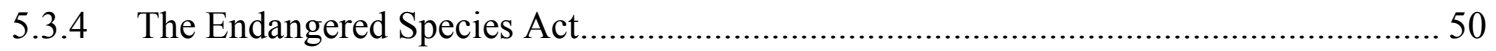

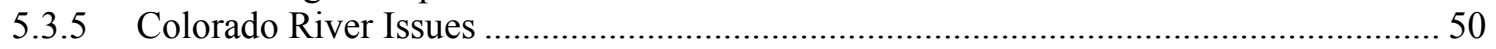

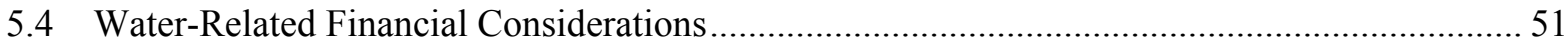

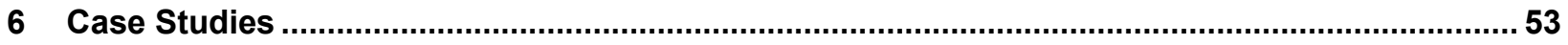

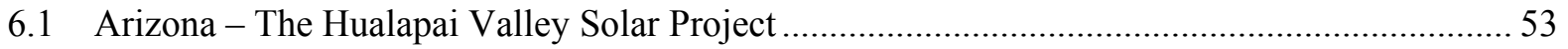

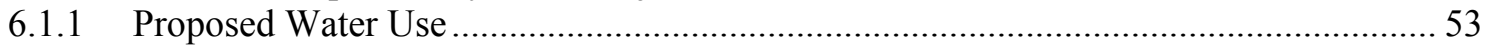

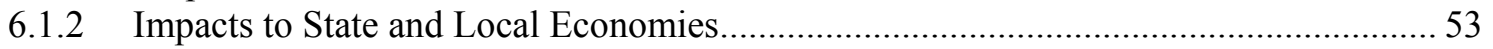

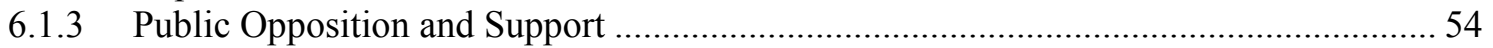

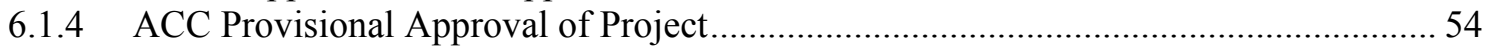

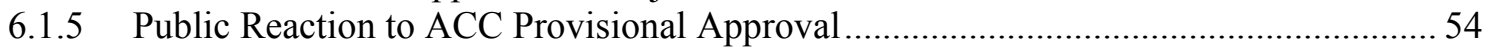

6.1.6 ACC Amendment of Project Water Mitigation Requirements.................................... 55

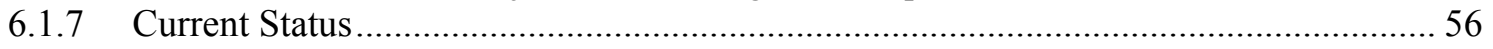

6.2 California - Genesis Solar Energy Project ......................................................................... 57

6.2.1 Original Proposed Use of Wet Cooling Technology ...................................................... 57

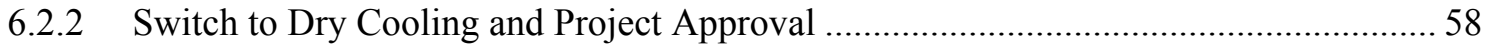

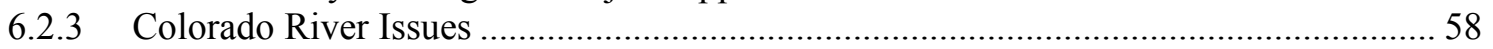

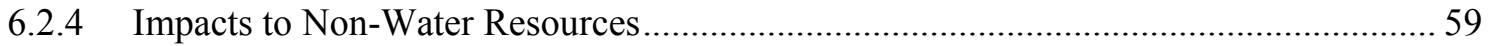

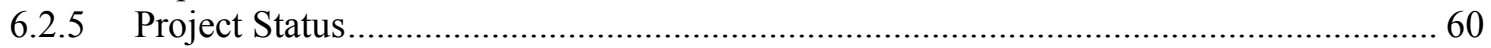

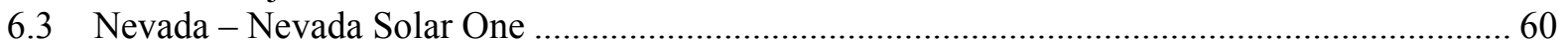

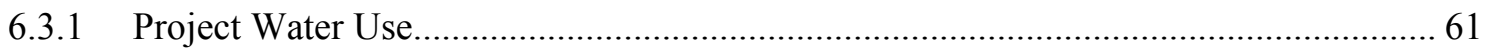

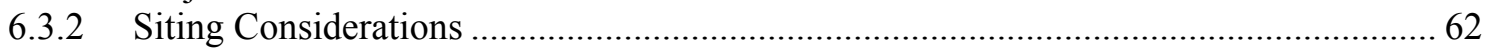

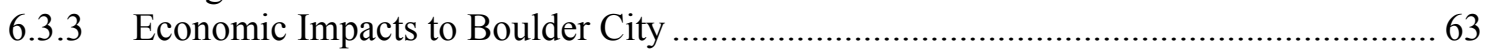

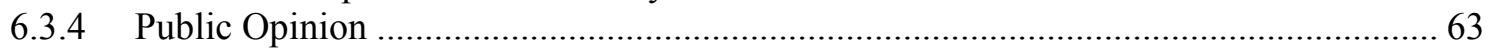

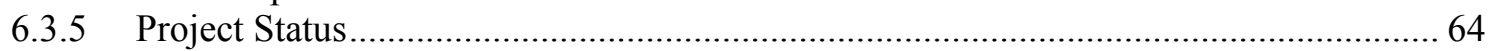

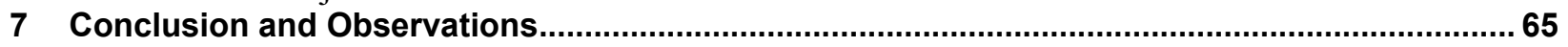

Appendix: Status of Utility-Scale CSP Projects in the United States ...........................................68

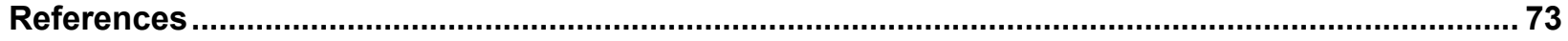




\section{Introduction}

In recent years, energy developers have proposed and built a number of large utility-scale concentrating solar power (CSP) projects in the southwestern United States.

As of August 2014, there were four CSP projects under construction and another 11 that have been proposed or are otherwise under development in the United States. Together with the 24 CSP projects that are already operational, these projects could potentially provide over 5,100 MW of low-emissions renewable electricity. Notably, $93 \%$ of these projects will be located in three states-Arizona, California, and Nevada, or the "Southwest" for the purposes of this report.

CSP plants concentrate the sun's energy to capture solar energy, which they then use to create heat to generate electricity. Every type of CSP plant requires some amount of water, with wetcooled plants typically requiring more water than many other forms of energy. However, the vast amounts of direct sunlight that make the Southwest so appealing for CSP development also mean that many of the most profitable locations for CSP sites are some of the most water scarce areas of the country. This has raised questions about the possible impacts of CSP development on water resources in the Southwest and how water availability will impact the siting of future plants.

At the same time, the federal government is taking a number of steps to encourage renewable energy development, including CSP, by offering various tax incentives and working to "fast track" the approval of large utility-scale renewable energy projects on federal land. Most recently, the Bureau of Land Management (BLM) approved a "roadmap" in October 2012 that would open 19 million acres of federal land in the Southwest, as well as Colorado, New Mexico, and Utah, for possible solar development. Under a reasonably foreseeable development scenario, BLM projects a total of almost $32 \mathrm{GW}$ of installed utility-scale solar project capacity on BLM and other federal land (e.g., surrounding U.S. Forest Service and Department of Defense) in these six states, representing 3\% of existing electricity capacity in the United States. BLM further estimates that by 2030 the total water demand for wet-cooled solar plants on BLM and other federal land, including CSP, could eventually total 221,000 acre-feet, and dry-cooled solar plants could total almost 18,000 acre-feet.

\subsection{The Energy and Water Policies of the Western Governors' Association}

The Western Governors' Association (WGA) has long advocated for a clean, diverse, reliable, and affordable energy supply consisting of a combination of traditional and renewable energy resources designed to move the country toward a truly balanced energy portfolio for the western states as well as a greater state of energy security and reliability. ${ }^{1}$ WGA's 2013 "10-Year Energy Vision" expressed a primary goal of the Governors to establish "an energy distribution infrastructure (electricity transmission and pipelines) planning, siting, and permitting system that facilitates the development of necessary infrastructure while maintaining wildlife, natural resource, and environmental protection." 2 With respect to water, WGA policy states that Western Governors "recognize that energy development and electricity generation may create new water demands [and] recommend increased coordination across the energy and water management communities." 3 
To further these policies and goals, WGA facilitated work by the Western Electricity Coordinating Council (WECC) on a Regional Transmission Expansion Planning Project (RTEP). The RTEP project was funded by the U.S. Department of Energy (DOE). This effort analyzed electricity transmission requirements under a broad range of alternative energy futures to help facilitate long-term, interconnection-wide transmission expansion plan development.

The Western States Water Council (WSWC) is also involved in incorporating western state information on water demand and availability into the transmission planning process to minimize impacts of potential future energy generation on the West's water resources. ${ }^{4}$ This report is intended to provide information on the various water supply and other related issues that impact CSP siting and development in the Southwest. 


\section{The Technology of Concentrating Solar Power}

CSP systems convert the sun's energy into high temperature heat by using mirrors to concentrate incoming energy. The resulting heat can be used to drive a turbine or an engine, producing electricity in a similar fashion to conventional power plants. CSP systems operate as low-carbon sources of electricity in that they do not produce greenhouse gas emissions because their primary fuel source is the sun, not fossil fuels, although some CPS project do use small amounts of natural gas to provide boiler stability, freeze protection, or supplemental power generation.

\subsection{CSP Technologies}

The four primary types of CSP technologies are parabolic troughs, power towers, linear Fresnel systems, and parabolic dish (Stirling engine) systems (Figure 1).

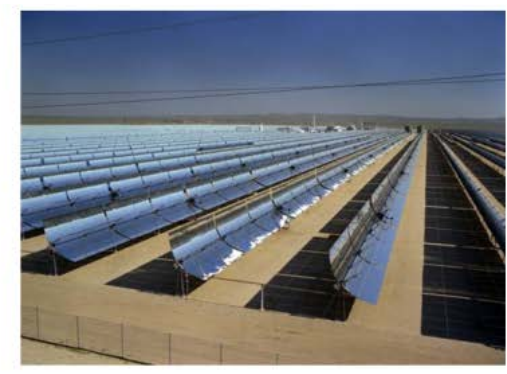

Parabolic Trough

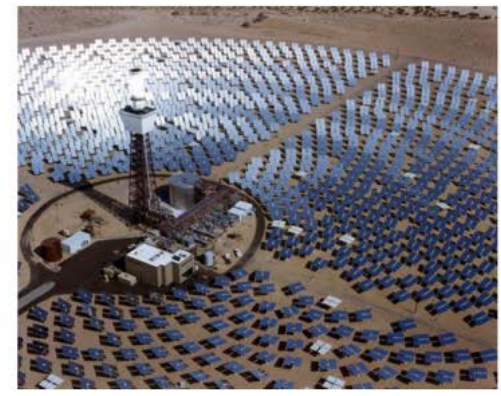

Power Tower

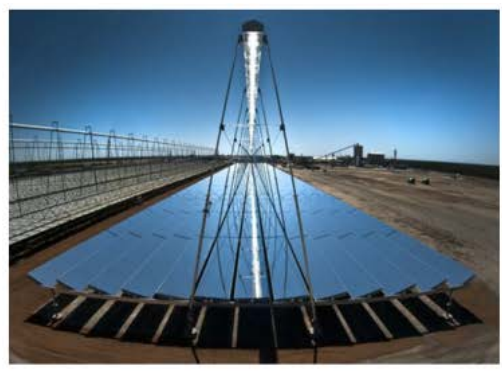

Linear Fresnel

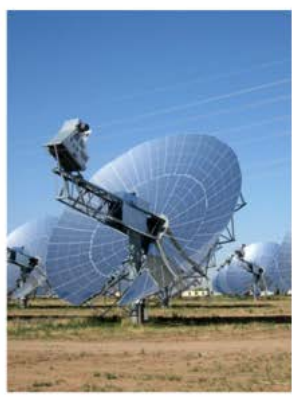

Parabolic Dish

Figure 1. The four primary types of CSP technologies

Photo by Warren Gretz, NREL 01225 (parabolic trough); from Sandia National Laboratories, NREL 00036 (power tower); from AREVA Solar, NREL 19882 (linear Fresnel); by David Hicks, NREL 18380 (parabolic dish)

Parabolic trough systems are the most commonly used CSP technology and comprise rows of trough-shaped mirrors that direct solar insolation to a receiver tube along the focal axis of each trough. The focused radiation raises the temperature of heat-transfer oil, which is used to generate steam. The steam then powers a turbine-generator to produce electricity.

Linear Fresnel systems operate similarly to parabolic trough systems but replace the troughshaped mirrors with a series of flat mirrors. The flat mirrors generally entail lower capital costs but result in lower system performance. 
Power tower systems consist of a field of sun-tracking mirrors called heliostats that direct insolation to a receiver atop a tall tower. Steam can be generated directly or a molten salt heattransfer fluid is heated in the receiver and is piped to a ground-based steam generator. The steam drives a turbine-generator to produce electricity.

Parabolic dish systems use a dish-shaped arrangement of mirror facets to focus energy onto a receiver at the focal point of the collector. A fluid or gas, such as hydrogen, is heated in the receiver and drives a turbine or Stirling engine. Most current dish applications propose using Stirling engine technology because of its potential high efficiency.

Because parabolic trough, Fresnel, and power tower systems collect heat to drive central turbine generators, they are best suited for large-scale plants that are $50 \mathrm{MW}$ or larger. Additionally, these plants can make use of thermal energy storage (TES) or hybrid systems that generate electricity using both solar energy and fossil fuels to achieve greater operating flexibility and dispatchability. Dish systems are modular in nature, with single units producing power in the range of $10 \mathrm{~kW}$ to $35 \mathrm{~kW}$. Thus, dish systems could be used for distributed or remote generation applications, or in large arrays of several hundred or thousand units to produce power on a utility scale.

\subsection{Thermal Energy Storage}

Parabolic troughs, power towers, and Fresnel systems have the ability to incorporate TES into their plant design, which allows them to operate similarly to some traditional fossil fuel-based electricity generating units. TES involves capturing solar energy during the day and storing it in the form of molten salts. During times of low sunlight, or during peak demands, this molten salt can be used to generate steam and drive turbines to produce electricity.

The flexibility resulting from the use of TES means that CSP can provide electricity to meet different load demands throughout the day given a sufficient amount of storage. Figure 2 shows the load curve for a typical summer day in California, breaking down baseload, intermediate, and peak loads. CSP could theoretically contribute to baseload power (similar to a nuclear or coal facility providing electricity 24 hours a day), intermediate power to meet load changes throughout the day (similar to a natural gas or hydro facility), and peaking demands (similar to a natural gas peaker plant) (Table 1). This flexibility and reliability, combined with their high efficiencies and large installed capacity sizes (100-1,000 MW), mean that CSP systems have the potential to provide significant amounts of renewable, relatively emissions-free energy. 


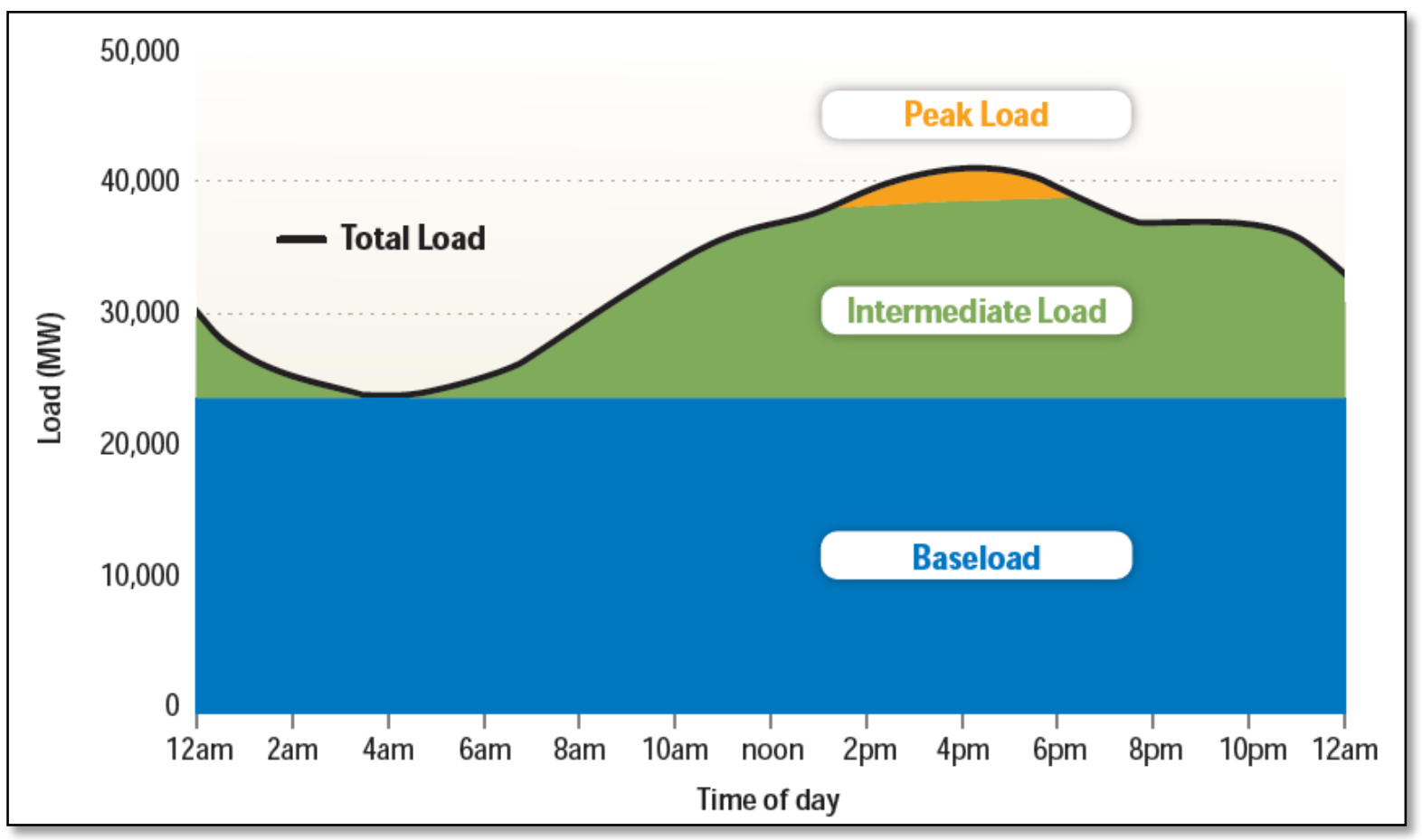

Figure 2. Typical load curve for a summer day in California in $2009 .^{5}$

Baseload refers to a constant demand that must be met. Intermediate load fluctuates throughout the day based on consumer demand. Peak load refers to the maximum electricity demand. Technologies capable of meeting different types of load are shown in

Table 1.

Table 1. Technologies That Have Capabilities to Meet Different Types of Electric Demand Load ${ }^{6}$

\begin{tabular}{|l|l|l|l|}
\hline Generator Type & Attributes of Generator & Conventional & Renewable \\
\hline Pust-Take & $\begin{array}{l}\text { Dependent on variable resource; requires } \\
\text { additional generation capacity }\end{array}$ & NA & $\begin{array}{l}\text { CSP without } \\
\text { storage; PV; } \\
\text { wind }\end{array}$ \\
\hline $\begin{array}{l}\text { Intermediate } \\
\text { Load }\end{array}$ & $\begin{array}{l}\text { Varies production to follow demand; } \\
\text { predictable availability }\end{array}$ & $\begin{array}{l}\text { Natural gas } \\
\text { combustion } \\
\text { turbine }\end{array}$ & CSP; PV \\
\hline combined cycle & $\begin{array}{l}\text { CSP with } \\
\text { storage; } \\
\text { hydropower }\end{array}$ \\
\hline Baseload & $\begin{array}{l}\text { Low fuel and operating costs; constant } \\
\text { rate of production; often very large to } \\
\text { Benefit from economy of scale }\end{array}$ & $\begin{array}{l}\text { Coal } \\
\text { Nuclear }\end{array}$ & $\begin{array}{l}\text { storage; } \\
\text { biomass; } \\
\text { geothermal; } \\
\text { hydropower }\end{array}$ \\
\hline
\end{tabular}

\subsection{Solar Resources in the United States}

CSP technologies require direct sunlight for operation. This direct sunlight is measured in terms of direct normal irradiance (DNI), or the amount of solar radiation from the direction of the sun. In contrast, photovoltaic (PV) systems operate using direct sunlight and diffuse sunlight, which occurs when sunlight is deflected by atmospheric obstacles such as clouds. Diffuse sunlight 
cannot be concentrated with mirrors. Thus, the best CSP sites are often located in areas with reliably clear skies and significant amounts of direct sun, like the Southwest (Figure 3).

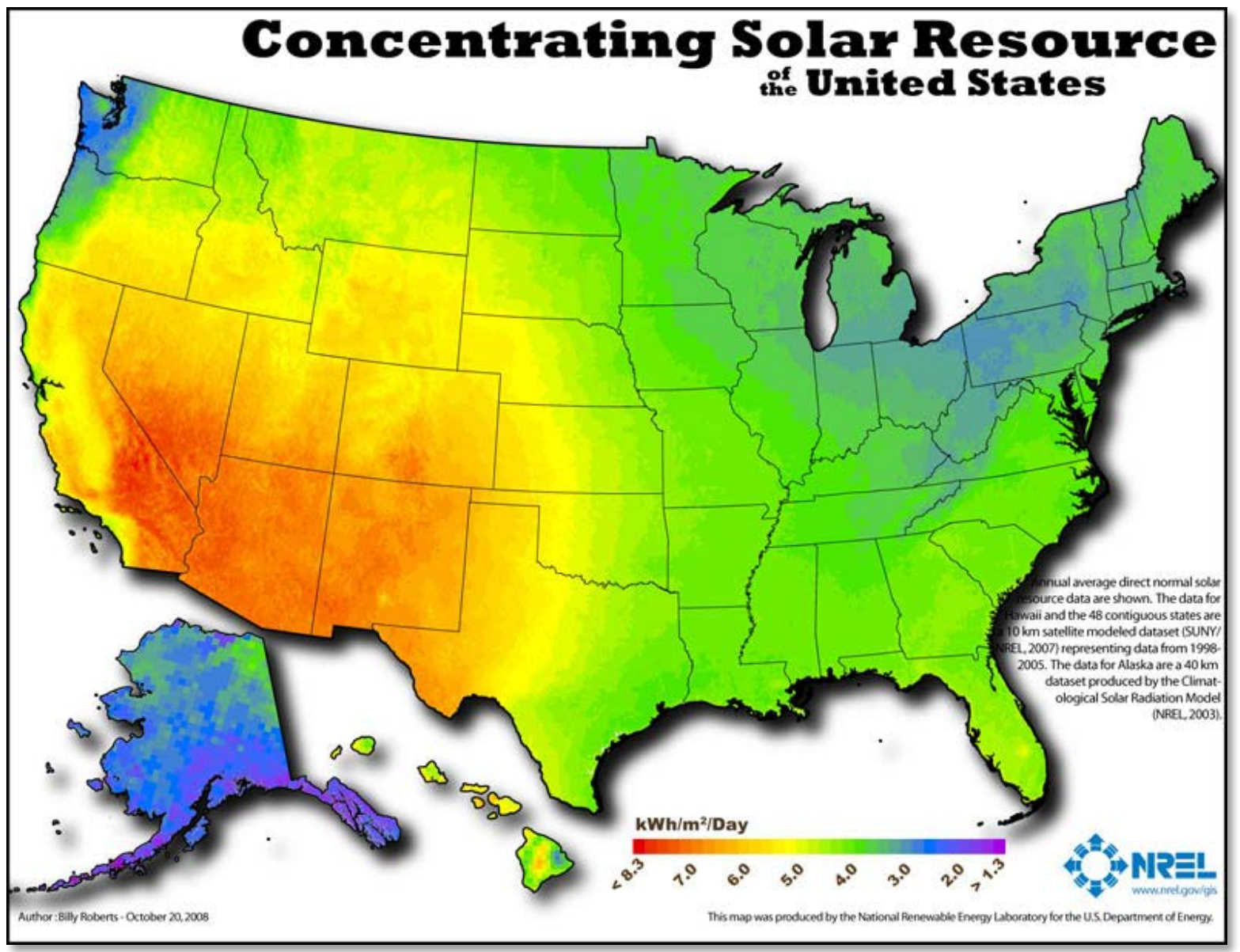

Figure 3. Average annual direct normal irradiance ${ }^{7}$

Beyond solar resources, CSP has additional siting requirements due to the properties of the technology. The land requirements for a CSP installation are approximately 4-15 acres/MW of installed capacity. ${ }^{8}$ The need for such large amounts of land means that CSP projects are often sited in remote desert locations far from population centers and surface water bodies. Figure 4 shows the theoretical potential land available for CSP deployment, considering a DNI greater than $6 \mathrm{kWh} / \mathrm{m}^{2} /$ day, land slope less than $1 \%$, and excluding areas such as sensitive environmental areas, urban areas, and water bodies. 


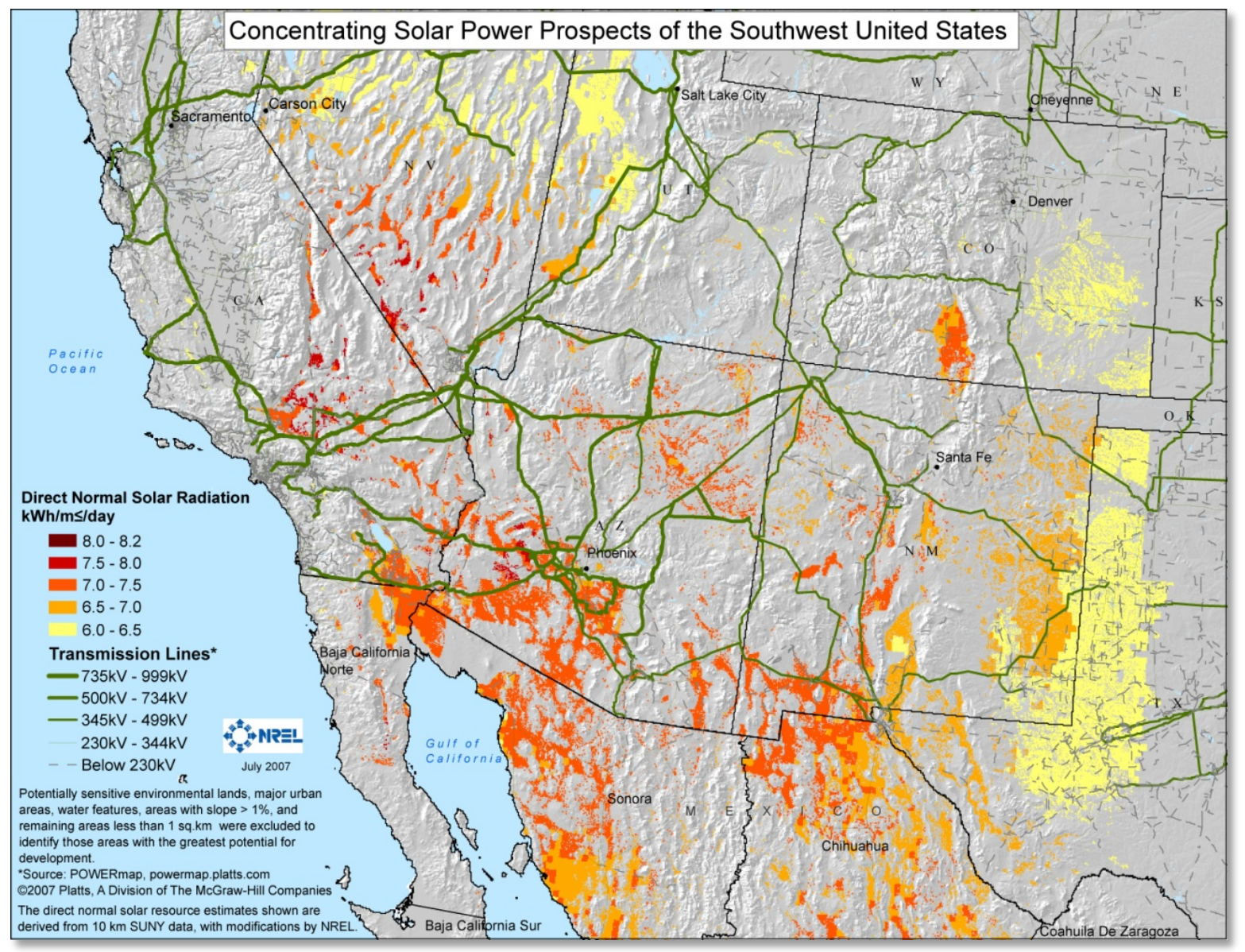

Figure 4. DNI resource of the U.S. Southwest filtered to show areas with the greatest potential for CSP deployment. ${ }^{9}$

DNI resources have been filtered to exclude potentially sensitive environmental lands, major urban areas, water bodies, areas with slope greater than $1 \%$, and contiguous areas less than $1 \mathrm{~km}^{2}$.

This land area corresponds to an installed CSP capacity of about 7,000 GW, or approximately $16,000 \mathrm{TWh}$ of electricity per year. This capacity is around six times greater than existing U.S. electric capacity $(1,100 \mathrm{GW})$, and the electricity output would be four times the current U.S. electricity demands $(4,100 \mathrm{TWh})$. CSP is not expected to deploy to these levels, but the large resource availability highlights the potential for CSP to be deployed in a variety of different locations in the Southwest.

\subsection{CSP Water Requirements by Process}

All CSP systems require some amount of water for operational processes. This includes water for construction, the steam cycle, and process cooling purposes, as well as the occasional cleaning of solar collectors or mirrors. Parabolic trough, linear Fresnel, and power tower CSP technologies rely on steam Rankine power cycles that are essentially the same as those used in coal and nuclear power plants. Completing the cycle in a Rankine power block requires a cooling system to condense steam back into water. While most water is reused in the cycle, water is still needed for the steam cycle make-up. 
There are three steam cycle cooling systems available to CSP facilities: wet-cooled, dry-cooled, and hybrid-cooled. A more efficient and commonly used cooling system is a wet-cooled system, also referred to as recirculating evaporative cooling, which uses a cooling tower. A dry-cooled system uses an air-cooled condenser for cooling purposes. A hybrid system can make use of both wet cooling and dry cooling that can be used separately or simultaneously depending on ambient temperatures, or alternatively can use water sprays or deluges in a dry-cooled system to reduce ambient temperatures. All types of CSP technologies can require thousands of acre-feet of water during construction depending on their size and type of technology.

Operational CSP water use by process is summarized below: ${ }^{10}$

- Wash water for mirrors requires 20-40 gallons/MWh.

- Makeup water for the steam cycle process water requires 30-60 gallons/MWh.

- Cooling system water requirements for the steam cycle process range from 0-900 gallons/MWh, depending on CSP technology and cooling system:

- A wet-cooled system can require between 750 and 900 gallons/MWh.

- Cooling requirements for auxiliary systems (if separate from steam cycle cooling) also depends on CSP technology and cooling system.

○ A dry-cooled system adds no additional water consumption.

- A hybrid-cooled system adds an amount somewhere between wet-cooled and drycooled values that is dependent on the frequency of use of the wet cooling.

Dish systems do not generally require water for cooling, nor for steam cycle operations, but do require a small amount to wash the concentrators.

\subsection{Cooling System Tradeoffs}

The performance, cost, and water impacts of CSP systems are partially dependent on their site's local climatic conditions. ${ }^{11}$ Beyond solar resources, temperature and humidity patterns are additional factors to consider. In general, CSP systems in hotter and drier areas have better solar resources but have lower thermoelectric plant efficiencies than CSP systems in cooler areas due to the fact that Rankine power cycle efficiencies are dependent on the temperatures of the heat sink. This lower plant efficiency leads to higher water consumption rates.

Climatic dependency is also apparent when assessing the performance penalties associated with switching from a wet-cooled system to a dry- or hybrid-cooled system. These penalties are greater in hotter, less humid areas. For instance, consider CSP system performance in the hot climate of Las Vegas, Nevada, and in the cooler climate of Alamosa, Colorado. Both areas have excellent solar resources but have very different climate profiles. These differences are summarized for parabolic trough technologies: ${ }^{12}$

- The water consumption rate (gallons of water per megawatt-hour generation) for a wetcooled CSP plant is $20 \%$ higher in hot areas like Las Vegas than in cooler areas like Alamosa. 
- Switching from a wet-cooled system to a dry-cooled system results in a $92 \%-93 \%$ reduction in water usage in both areas.

- Hybrid-cooled CSP systems will consume more water in hot areas like Las Vegas than in cooler areas like Alamosa, as the cooling tower will need to be employed more.

- The performance penalty associated with switching from a wet-cooled system to a drycooled system results in a decline in annual electricity output dependent on climate, ranging from $2 \%$ (Alamosa) to 5\% (Las Vegas).

- The cost penalty associated with switching from a wet-cooled system to a dry-cooled system results in a climate-dependent increase in the levelized cost of energy (LCOE) of $2.5 \%$ (Alamosa) to $8 \%$ (Las Vegas). ${ }^{13}$

Climate-specific conditions must be taken into consideration when analyzing the water impacts of electricity generation and water intensity, including CSP technologies. Additionally, increasing drought and other climate conditions can impact the micro-climates in the Southwest, meaning a clearer understanding of the relationships between local climatic factors and CSP system performance and water intensity are necessary for better risk management.

\subsection{Comparison of CSP Water Requirements With Other Electricity Generating Technologies}

Given that CSP systems can displace power from other electricity generation sources, it is important to consider CSP water use in the context of other technologies and cooling systems. Figure 5 compares CSP's water use with other technologies. Recirculating cooling, once-through cooling, and pond cooling are all collectively referred to as wet-cooled. 


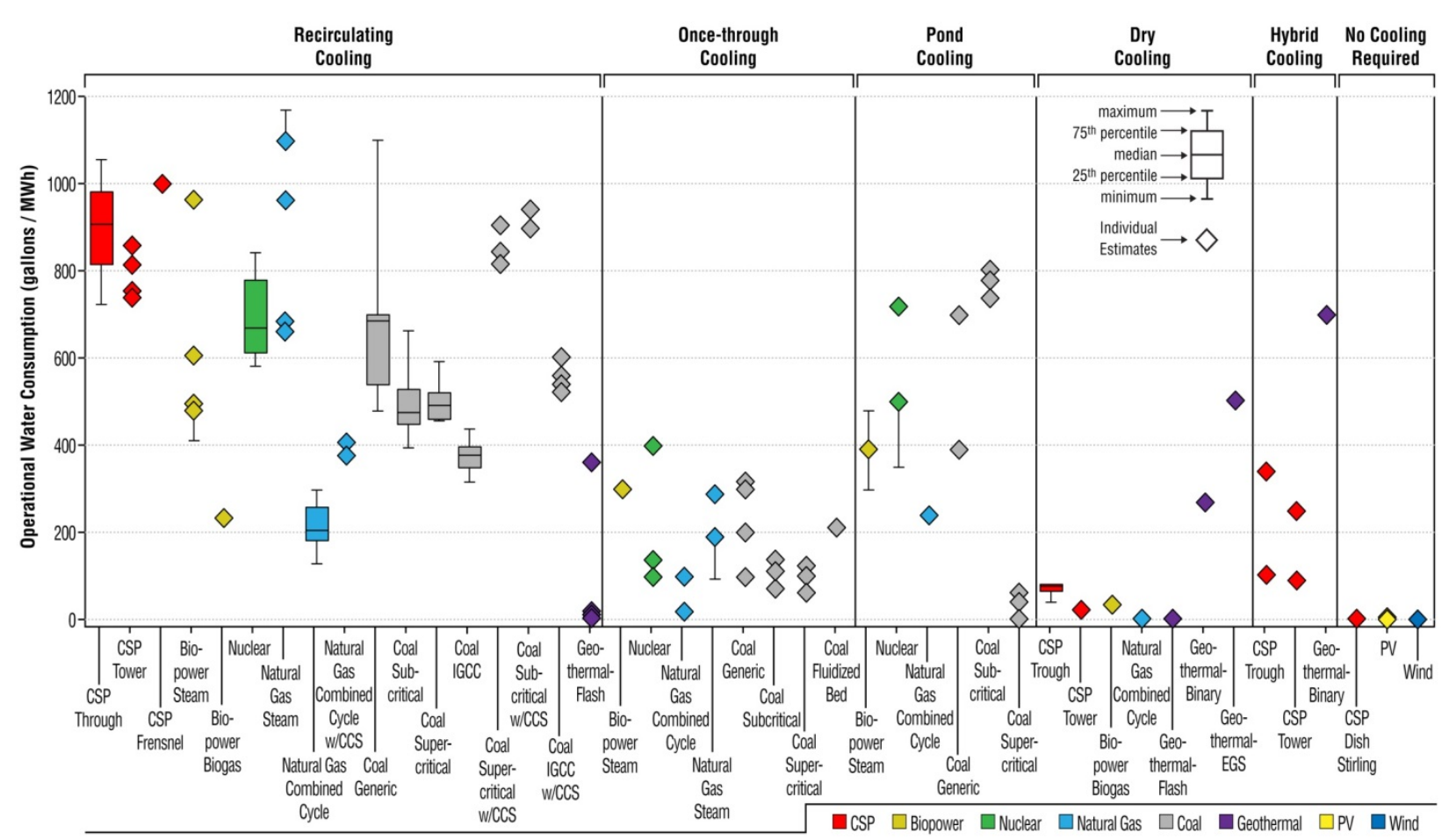

Figure 5. Operational water consumption requirements for electricity generating technologies ${ }^{14}$

In general, CSP water consumption relates to other technologies in the following ways:

- CSP systems with recirculating cooling technologies have higher water consumption rates (in terms of gallons per MWh) than many other wet-cooled technologies.

- A wet-cooled coal system with carbon capture capabilities can consume more water than a wet-cooled CSP system.

- Dry-cooled CSP systems have lower water use rates than competing nuclear, coal, and natural gas facilities using cooling towers. They have similar water impact to natural gas facilities employing dry cooling.

- Hybrid system water use depends upon how frequently the cooling tower is utilized, but studies have shown that CSP hybrid-cooled systems consume less water than existing (wet-cooled) coal, natural gas, and nuclear power plants in some areas.

- PV systems do not require water for cooling purposes because they turn the sun's energy directly into electricity rather than heat and therefore require considerably less water than CSP. PV plants do require water for mirror washing, dust suppression, and potable uses.

\subsection{Comparison of CSP Water Requirements With Other Land Uses}

As CSP systems require a considerable amount of land and water, it is important to compare CSP's water consumption intensity (in terms of volume of water per acre) with other existing land uses. Some CSP facilities are being sited on old agricultural land and efforts are currently being made to ensure that CSP development occurs on disturbed and contaminated lands that likely have limited biological resource value. ${ }^{15} \mathrm{CSP}$ wet-cooled facilities consume approximately one-third of the amount of water per acre as common crops in the Southwest, such 
as alfalfa and cotton, and about one-half as much water per acre as a golf course (Figure 6). Thus, a wet-cooled CSP facility located on disturbed agricultural land might use less water than previous agricultural activities and could help to reduce water stress in that area. Of course, agriculture provides many benefits to a community and is an important component of the Southwestern economy and culture. If agricultural productivity is low, there could be a multifactored decision about the best use of that land, with CSP being one alternative use. The multiple benefits of agriculture would figure prominently in that decision, along with any benefits of any alternative land use, including CSP technologies.

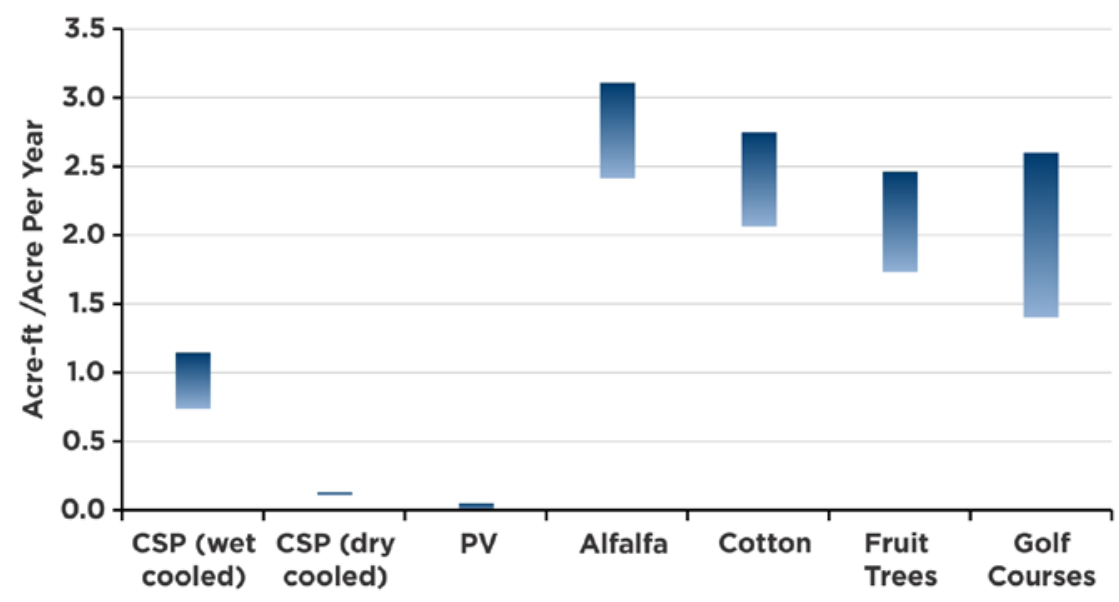

Figure 6. Comparison of CSP and PV water requirements with other common land uses in the U.S. Southwest, in acre-feet per acre per year. ${ }^{16}$

One acre-foot is approximately 325,851 gallons. 


\section{CSP Development in the United States and Southwest}

CSP and renewables as a whole currently represent a very small portion of the U.S. electricity generation and capacity portfolio, with CSP providing $0.03 \%$ and $0.1 \%$, respectively (Table 2 ). Although it is possible that CSP could greatly expand in the future, the extent to which the technology is able to expand will depend on a number of factors.

\subsection{Current Extent of CSP Development}

As of August 2014, total CSP development in the United States consisted of 39 projects with $5,101 \mathrm{MW}$ of capacity, including 24 operational CSP plants $(1,495 \mathrm{MW}), 4$ plants under construction (366 MW), and 11 plants under development or otherwise proposed $(3,240 \mathrm{MW}){ }^{17}$ All but five of these projects are located in the Southwest. Please see the Appendix for a full list of CSP projects. With respect to other solar technologies, the total PV development for the United States includes 515 projects with an operating capacity of 27,024 MW, most of which are under construction, have been proposed, or are otherwise under development. For concentrating PV (CPV), which concentrates sunlight onto a small area of PV cells to generate electricity directly, the total includes 9 projects with an operating capacity of (272 MW) (Appendix).

Table 2. U.S. Electricity Generation and Capacity Portfolio (2012) ${ }^{18}$

\begin{tabular}{|l|c|c|}
\hline Technology & Generation (\%) & Capacity (\%) \\
\hline Coal & $37.4 \%$ & $28.8 \%$ \\
\hline Natural Gas & $30.3 \%$ & $41.6 \%$ \\
\hline Nuclear & $19.0 \%$ & $9.2 \%$ \\
\hline Hydropower & $6.8 \%$ & $6.7 \%$ \\
\hline Biomass & $1.4 \%$ & $1.2 \%$ \\
\hline Geothermal & $0.4 \%$ & $0.3 \%$ \\
\hline Wind & $3.5 \%$ & $5.1 \%$ \\
\hline PV & $\mathbf{0 . 1 \%}$ & $\mathbf{0 . 2} \%$ \\
\hline CSP & $\mathbf{0 . 0 3 \%}$ & $\mathbf{0 . 1 \%}$ \\
\hline Other & $1.0 \%$ & $6.8 \%$ \\
\hline
\end{tabular}

Among operational CSP systems, approximately 90\% of existing capacity utilizes the parabolic trough system technology. Sixty percent of capacity under construction is for parabolic trough systems, with the remaining $40 \%$ being power tower systems. Most operational plants are in California (Figure 7). 


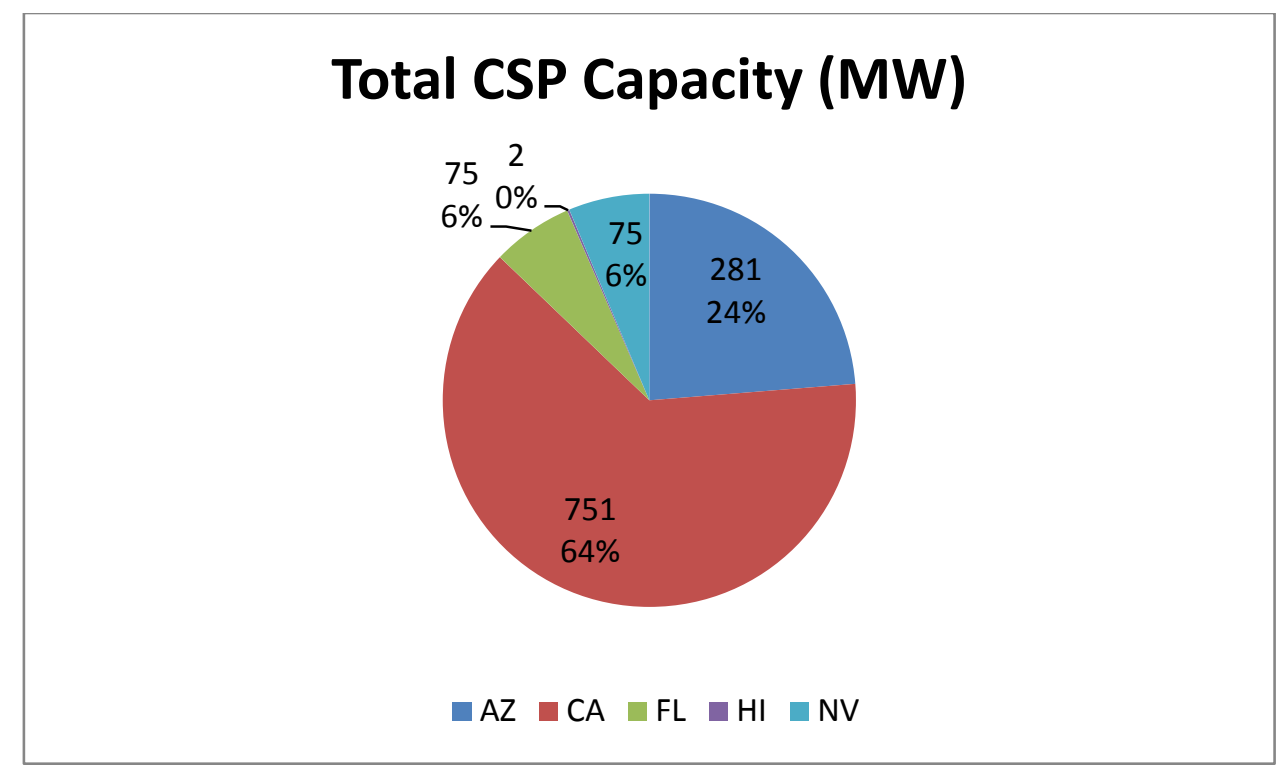

Figure 7. Installed capacity of CSP projects by state ${ }^{19}$

Values indicate total installed CSP capacity in MW as well as percentage of national total as of March 2014.

\subsection{State and Federal Efforts to Encourage CSP}

States and the federal government use a variety of mechanisms and incentives to facilitate and encourage renewable energy development, including CSP. These mechanisms vary considerably and include state requirements that certain percentages of electricity generation come from renewable energy, state and federal tax incentives, and federal efforts to encourage renewable energy development on federal lands.

\subsubsection{State Renewable Portfolio Standards}

State renewable portfolio standards (RPS) are one of the motivating factors spurring CSP development in the Southwest. These standards require certain types of utilities to acquire or generate a percentage of renewable energy through a combination of solar, wind, biomass, landfill gas, ocean, geothermal, and other sources. ${ }^{20}$

Although the specifics vary, all three of the states discussed in this report have adopted RPSs. In general, these standards set milestones for renewable energy production that begin on a certain date and increase on an annual basis until reaching their final targets, which are set to be achieved in the 2020s. RPSs for the states discussed in this report are shown in Table 3. 
Table 3. RPS Milestones for Arizona, California, and Nevada ${ }^{21}$

\begin{tabular}{|c|c|c|}
\hline State & RPS & Compliance Schedule \\
\hline $\mathrm{AZ}$ & $\begin{array}{l}\text { - } 15 \% \text { by } 2025 \\
\text { - } 30 \% \text { of the renewable energy must come from } \\
\text { distributed renewable (DR) technologies by } 2012 \\
\text { and thereafter } \\
\text { - One-half of the distributed renewable energy } \\
\text { requirement must come from residential } \\
\text { installations and the remaining half from non- } \\
\text { residential, non-utility installations }\end{array}$ & 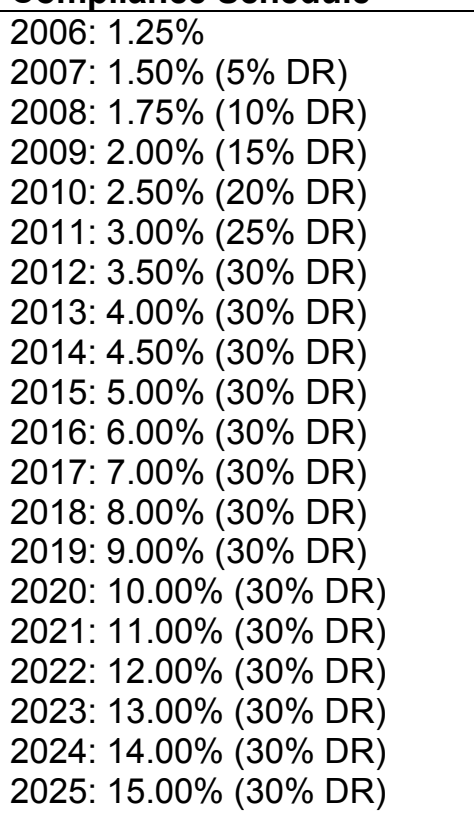 \\
\hline $\mathrm{CA}$ & - $33 \%$ by 2020 & $\begin{array}{l}20 \% \text { by the end of } 2013 \\
25 \% \text { by the end of } 2016 \\
33 \% \text { by } 2020\end{array}$ \\
\hline NV & $\begin{array}{l}\text { - } 25 \% \text { by } 2025 \\
\text { - } 5 \% \text { of renewable energy must come from solar } \\
\text { through } 2015 \text { and account for } 6 \% \text { beginning in } \\
2016 \\
\text { - Energy efficiency measures can be used to satisfy } \\
\text { up to one-quarter of the RPS in any particular } \\
\text { year. To qualify, the efficiency measures must } \\
\text { reduce a customer's energy demand and be: (1) } \\
\text { implemented after January } 1,2005 ;(2) \text { sited or } \\
\text { implemented at a retail customer's location; and } \\
\text { (3) fully or partially subsidized by the electric utility }\end{array}$ & $\begin{array}{l}\text { 2005- Establish an energy } \\
\text { distribution infrastructure } \\
\text { (electricity transmission and } \\
\text { pipelines) planning, siting } \\
\text { and permitting system that } \\
\text { facilitates the development of } \\
\text { necessary infrastructure while } \\
\text { maintaining wildlife, natural } \\
\text { resource, and environmental } \\
\text { protection. } \\
2006: 6 \% \\
2007-2008: 9 \% \\
2009-2010: 12 \% \\
2011-2012: 15 \% \\
2013-2014: 18 \% \\
2015-2019: 20 \% \\
2020-2024: 22 \% \\
2025 \text { and thereafter: } 25 \%\end{array}$ \\
\hline
\end{tabular}

These standards appear to be one of the primary factors encouraging utility companies to include solar energy within their portfolios. For example, Arizona's RPS has prompted the Tucson Electric Power Company (TEP) to take action to expand its renewable portfolio and to seek to purchase power from various solar projects, including a proposed CSP facility. ${ }^{22}$ Likewise, California's RPS has played a role in stimulating solar development, including CSP plants. ${ }^{23}$ 
However, utilities have raised concerns about compliance costs associated with RPS requirements, which are passed on to utilities and eventually to consumers. ${ }^{24}$ In TEP's case, a 2010 report found that the added cost to each consumer is about $\$ 3$ per month. ${ }^{25}$ Although this amount may seem relatively small, some observers have stated that utilities will likely pass any and all additional costs on to consumers, which could add up to more substantial amounts. ${ }^{26}$

It is also important to note that of the states discussed in this report, only Nevada has specific goals for solar development, requiring that at least $5 \%$ of renewable energy projects must come from solar energy (Table 3). To some solar industry experts, the lack of such requirements in other states, including California and Arizona, could create an incentive for utilities to import renewable energy from other states or to produce renewable energy from sources other than solar. ${ }^{27}$

\subsection{State Financial Incentives}

State and local governments in the Southwest provide a variety of financial incentives aimed at encouraging the development of renewable energy, such as CSP. These include various tax credits, grants, loans, rebates, and other incentives. Although the impacts of these incentives vary, they do have the potential to provide significant financial savings to developers. For instance, annual property taxes for the Genesis Solar CSP project under construction in California are $\$ 627,000$ under the state's property tax exemption for solar systems, which is set to expire during the 2015-2016 fiscal year. If the exemption expires, the project's estimated annual property taxes would increase to about $\$ 10.5$ million. ${ }^{28}$ Table 4 contains a sampling of renewable energy incentives in the Southwest. 
Table 4. Examples of State-Based Renewable Energy Incentives ${ }^{29}$

\begin{tabular}{|c|c|c|}
\hline State & Tax Credit & Description \\
\hline \multirow[t]{4}{*}{$A Z$} & $\begin{array}{l}\text { Renewable Energy } \\
\text { Production Tax } \\
\text { Credit }^{30}\end{array}$ & $\begin{array}{l}\text { The tax credit is based on the amount of electricity produced annually for a } \\
10 \text {-year period. For solar systems, the credit depends on the year of } \\
\text { production and ranges from } \$ 0.04 / \mathrm{kWh} \text { in the first year to } \$ 0.01 / \mathrm{kWh} \text { in the } \\
\text { tenth year. The maximum credit that can be claimed for any one year is } \$ 2 \\
\text { million. }\end{array}$ \\
\hline & $\begin{array}{l}\text { Non-Residential } \\
\text { Solar and Wind } \\
\text { Credit }^{31}\end{array}$ & $\begin{array}{l}\text { Tax credit can be applied against corporate or personal taxes. It is equal } \\
\text { to } 10 \% \text { of the installed cost of qualified solar energy devices and applies to } \\
\text { tax years beginning in } 2006 \text { and extending through } 2018 \text {. The maximum } \\
\text { credit per taxpayer is } \$ 25,000 \text { for any one building and } \$ 50,000 \text { in total } \\
\text { credits in any year. }\end{array}$ \\
\hline & $\begin{array}{l}\text { Property Tax } \\
\text { Assessment for } \\
\text { Renewables and } \\
\text { Efficiency }^{32}\end{array}$ & $\begin{array}{l}\text { Assesses renewable energy equipment owned by utilities and other } \\
\text { entities operating in Arizona at } 20 \% \text { of its depreciated cost for the purpose } \\
\text { of determining property tax. }\end{array}$ \\
\hline & $\begin{array}{l}\text { Solar Sales Tax } \\
\text { Incentive }^{33}\end{array}$ & $\begin{array}{l}\text { Allows retailers to deduct amounts received from the sale of solar energy } \\
\text { devices from their transaction privilege tax base and allows contractors to } \\
\text { deduct the proceeds from the installation of qualifying devices from their } \\
\text { transaction privilege tax base. }\end{array}$ \\
\hline \multirow[t]{3}{*}{$\mathrm{CA}$} & $\begin{array}{l}\text { Property Tax } \\
\text { Exclusion for Solar } \\
\text { Energy Systems }\end{array}$ & $\begin{array}{l}\text { Certain types of solar energy systems installed between January } 1,1999, \\
\text { and December } 31,2016 \text {, are excluded from property tax. Dual use } \\
\text { systems for solar-electric systems qualify for the exemption only to the } \\
\text { extent of } 75 \% \text { of their value. }\end{array}$ \\
\hline & $\begin{array}{l}\text { Renewable Auction } \\
\text { Mechanism (RAM) }\end{array}$ & $\begin{array}{l}\text { RAM is a market-based reverse auction intended to streamline the } \\
\text { procurement process for renewable distributed energy generation projects } \\
\text { up to } 20 \mathrm{MW} \text {. }\end{array}$ \\
\hline & $\begin{array}{l}\text { California Solar } \\
\text { Initiative }(\mathrm{CSI})^{36}\end{array}$ & $\begin{array}{l}\text { CSI provides rebates for PV systems that range from } \$ 0.20 \text { to } \$ 0.35 \text { per } \\
\text { AC watt for residential and commercial systems and from } \$ 0.70 \text { to } \$ 1.10 \\
\text { for non-profits and government entities. The initiative has a total budget of } \\
\$ 2.167 \text { billion between } 2007 \text { and } 2016 \text { and a goal to install approximately } \\
1,940 \mathrm{MW} \text { of new solar generation capacity. }\end{array}$ \\
\hline \multirow[t]{4}{*}{$\mathrm{NV}$} & $\begin{array}{l}\text { Portfolio Energy } \\
\text { Credits }^{37}\end{array}$ & $\begin{array}{l}\text { Renewable energy producers can earn Portfolio Energy Credits (PECs) } \\
\text { that they can sell to utilities meet the state's RPS. }\end{array}$ \\
\hline & $\begin{array}{l}\text { State Loan } \\
\text { Program }\end{array}$ & $\begin{array}{l}\text { Revolving loan fund that provides short-term low-interest loans to } \\
\text { renewable energy projects. The minimum and maximum loan amounts are } \\
\$ 100,000 \text { and } \$ 1 \text { million, respectively. Loans cannot exceed } 15 \text { years. }\end{array}$ \\
\hline & $\begin{array}{l}\text { Sales and Use Tax } \\
\text { Abatement }^{39}\end{array}$ & $\begin{array}{l}\text { Purchasers of qualifying renewable energy technologies pay sales and } \\
\text { use taxes at } 2.25 \% \text {. Generation facilities must have a capacity of at least } \\
10 \mathrm{MW} \text {, while solar facilities must generate at least } 25.8 \text { million British } \\
\text { thermal units (BTUs) of process heat per hour. }\end{array}$ \\
\hline & $\begin{array}{l}\text { Large-Scale } \\
\text { Renewable Energy } \\
\text { Property Tax } \\
\text { Abatement }^{40}\end{array}$ & $\begin{array}{l}\text { Property tax abatements of up to } 55 \% \text { for up to } 20 \text { years are available } \\
\text { through the Nevada Office of Energy for real and personal property used } \\
\text { to generate renewable electricity. Generation facilities must have a } \\
\text { capacity of at least } 10 \mathrm{MW} \text {, while solar facilities must generate at least } \\
25.8 \text { million BTUs of process heat per hour. }\end{array}$ \\
\hline
\end{tabular}

\subsection{Federal Incentives}

The federal government provides a number of financial incentives to encourage renewable energy development, including CSP. One notable incentive is the investment tax credit (ITC), which provides solar projects a tax credit of up to $30 \%$ on the capital costs of a project with no maximum credit amount. The credit is generally available for eligible systems placed in service on or before December 31, 2016. ${ }^{41}$ 
Congress also passed the Energy Policy Act (EPAct) in 2005 to "ensure jobs for our future with secure, affordable, and reliable energy." ${ }^{2}$ To accomplish this goal, the EPAct states that the U.S. Department of the Interior should act to approve renewable energy projects on federal lands before the end of 2011. Moreover, it appropriated over $\$ 50$ billion for DOE loan guarantees aimed at supporting clean energy projects that use innovative technologies and spurred further investment in such technologies ${ }^{43}$ Guarantees can equal up to $80 \%$ of a facility's cost, but the EPAct only provided loan guarantees for the "early commercial use of innovative technologies," which did not necessarily include utility-scale solar projects. ${ }^{44}$

Congress later extended the loan guarantees to include traditional renewable energy systems when it passed the American Recovery and Reinvestment Act (ARRA) of 2009. ARRA authorized an additional $\$ 6$ billion to support loan guarantees and about $\$ 21$ billion in tax incentives but required companies to break ground before December 31, 2011 to qualify for grants. This requirement led to the filing of a significant number of right-of-way applications with BLM, which had received as many as 188 applications for solar projects on federal lands as of July $2010 .^{45}$

\subsection{CSP Development on Federal Land}

In recent years, the executive and legislative branches have employed a variety of means to promote solar energy (both CSP and PV) development on federal lands. Much of the federal land that is most suitable for CSP development falls under the jurisdiction of BLM, which manages millions of acres of federal land and is responsible for approving the necessary rights-of-way needed to construct utility-scale solar projects on those lands. ${ }^{46}$

BLM's current Solar Energy Development Policy is designed to "facilitate environmentally responsible commercial development of solar energy projects on [federal] lands." To this end, the agency approved the first utility-scale solar projects on federal land in 2010 and has approved a total of 28 projects since 2010 . These projects have the potential to generate $8,556 \mathrm{MW}$ of energy and range in size from a $45 \mathrm{MW}$ PV system on 422 acres to a 1,000 MW parabolic trough CSP project on 7,025 acres. Another 70 solar projects have been proposed on federal lands, primarily in Arizona, California, and Nevada. ${ }^{47}$

This subsection describes the basic elements of the process BLM uses to approve rights-of-way for solar projects on federal lands and also discusses recent efforts by the agency to facilitate solar development, including a "fast-track" approval process and changes to its current policies that would make over 19 million acres of federal land available for solar development.

\subsubsection{The Federal Land Policy Management Act}

The Federal Land Policy Management Act (FLPMA) is the principal law that governs how BLM manages federal lands. Under the FLPMA, BLM must prepare and maintain land-use plans pertaining to the protection, management, development, and enhancement of federal lands. These plans must apply the principles of sustainable yield and multiple uses and consider both present and potential uses of federal lands. As such, land-use plans can allow for a range of uses, including CSP development, so long as they allow for the use of public resources in a way that best meets the current needs of the American people and the long-term needs of future generations. When developing land-use plans, BLM must consider the value of resources located on federal lands without necessarily promoting those uses with the greatest economic return. 
Importantly, the FLMPA also requires BLM to ensure the protection of the environmental resources it manages and to provide "habitat for fish and wildlife." 48

BLM allows for the installation of CSP and other solar projects on federal lands by authorizing rights-of-way for such projects under Title V of the FLPMA. In order to authorize a right-ofway, BLM must determine on a case-by-case basis whether the project is consistent with its landuse planning priorities, and entities receiving a right-of-way must comply with the terms of the authorization and pay fair market value for the use of federal lands. ${ }^{49}$ BLM also assesses a project's potential impacts on environmental resources, including water, in accordance with applicable laws. $^{50}$

The FLPMA requires BLM to honor state laws and coordinate with applicable state and local governments when authorizing rights-of-way on public lands. To this end, BLM rights-of-way must include terms and conditions that:

[R] equire compliance with applicable air and water quality standards established by or pursuant to applicable Federal or State law... [and] State standards for public health and safety, environmental protection, and siting, construction, operation, and maintenance of or for rights-of-way for similar purposes if those standards are more stringent than applicable Federal standards. ${ }^{51}$

The FLPMA and its implementing regulations also require BLM to provide the public with opportunities to express concerns about proposed projects and contribute to the agency's rightof-way decision-making process. ${ }^{52}$

\subsubsection{National Environmental Policy Act}

The National Environmental Policy Act (NEPA) requires federal agencies that are contemplating a "major Federal action significantly affecting the quality of the human environment" to study the possible environmental impacts of its actions. NEPA applies to most BLM decisions to grant a right-of-way for CSP development on federal lands, and the agency will usually prepare what is known as an "environmental assessment"(EA) for a right-of-way application. If the EA finds that no significant environmental impacts will occur, including impacts to water, it will make a finding of no significant impact. However, if significant environmental impacts are likely, BLM must prepare a detailed environmental impact statement (EIS) that considers the environmental impacts of the proposed action, as well as social and economic impacts and all reasonable alternatives, including a "no action" alternative. ${ }^{53}$ According to some reports, the cost of completing environmental impact studies can range from $\$ 5$ million to $\$ 6$ million, with costs generally assessed to the applicant. ${ }^{54}$

Notwithstanding BLM's efforts to encourage solar development on federal land, many CSP developers prefer to site their projects on private land to avoid NEPA and other federal requirements, which can add to the costs and time needed to complete a project. Such has been the case in Arizona where project sponsors have largely avoided siting their projects on federal lands. ${ }^{55}$ However, in California, private lands in suitable areas are highly parcelized and the effort and ability needed to create a large, contiguous area is a constraint that often means developers have little choice but to site their projects on federal land. ${ }^{56}$ 


\subsubsection{BLM's "Fast-Track" Approval Process}

In 2009, BLM began using a "fast-track" process to review and approve right-of-way applications for renewable energy projects proposed for federal lands to ensure that approved projects would qualify for federal ARRA financial assistance ${ }^{57}$ Under the process, BLM created a list of priority energy projects for expedited review and processing. Selected projects included those that BLM had determined to have made enough progress in the necessary environmental review and public participation processes that it was possible for the projects to be cleared by December 2010, making them eligible for ARRA funding. ${ }^{58}$

As with BLM's normal right-of-way review process, the fast-track process reviewed the environmental impacts associated with solar development and included consultation with state and local governments. ${ }^{59}$ The specifics of this consultation have varied according to each state and project but have included such things as joint state-federal technical analysis, joint public meetings and workshops, and joint document review to ensure consistency, among other efforts. ${ }^{60}$

Some have criticized BLM for moving too fast to approve fast-tracked projects at the expense of environmental and other resources. For example, some environmental groups objected to the speed in which BLM approved right-of-way applications, arguing that the agency was unable to give sufficient consideration to potential impacts. Others argued that the impetus to approve projects quickly within the timeframe imposed by ARRA trumped the need for the thorough evaluation of environmental impacts. ${ }^{61}$

However, BLM has justified the use of this fast-track process by arguing that the approved renewable energy projects have the capacity to displace conventional energy production facilities that produce greenhouse gasses. It further maintains that it used suitable environmental policies, procedures, and mitigation strategies in reviewing proposed CSP projects, and that it took all practical steps to comply with applicable environmental laws. ${ }^{62}$

\subsubsection{Federal Solar "Roadmap" for Utility-Scale Solar Development on Federal Lands}

In October 2012, the Obama Administration approved a Programmatic Environmental Impact Statement (PEIS) or possible "roadmap" for solar energy development that considers replacing elements of its current energy solar policies with a comprehensive "Solar Energy Program" that would allow the permitting of future solar energy projects on public lands to proceed in a "more efficient, standardized, and environmentally responsible manner." ${ }^{93}$ In particular, the PEIS evaluates potential actions the agencies are considering to further facilitate utility-scale solar energy development in Arizona, California, Colorado, Nevada, New Mexico, and Utah. For BLM, such actions include the evaluation of a new Solar Energy Program applicable to solar development on BLM-administered lands. DOE efforts would include the evaluation and development of new guidance to facilitate utility-scale solar energy development and mitigation of potential environmental impacts. ${ }^{64}$

The PEIS is intended to move BLM away from considering individual solar projects on a caseby-case basis by directing projects to specific locations or "Solar Energy Zones" that have a relatively low potential for conflict with environmental, cultural, and historic resources as well as good energy transmission potential and possible economic benefits. In total, the PEIS identifies 
17 solar zones encompassing about 285,000 acres of federal lands as priority areas for utilityscale solar development (Figure 8). ${ }^{65}$

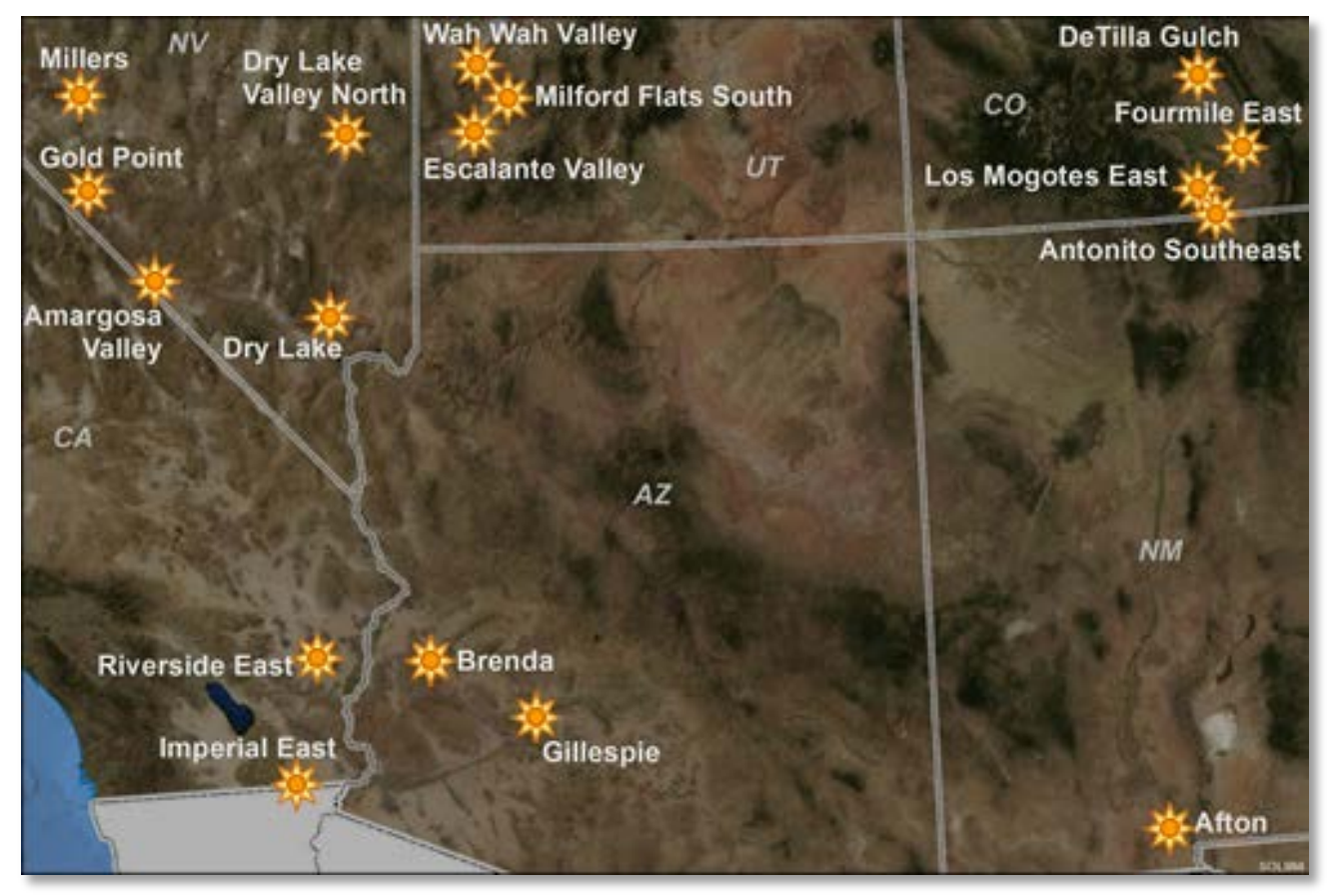

Figure 8. Proposed solar energy zones of the Solar Energy Development PEIS ${ }^{66}$

The PEIS excludes a little under 79 million acres from solar development where BLM determined that environmental, historical, and cultural resources could be impaired by development. It also provides incentives to encourage development in the solar energy zones, including quicker permitting, mitigation strategies, and economic incentives. Moreover, the PEIS identifies design features, or best practices, for solar development that are aimed at ensuring environmentally responsible development. ${ }^{67}$

In addition to the solar energy zones, the PEIS allows for solar development on 19 million acres in "variance" areas outside of the zones. Altogether, the PEIS encompasses a total development of $23,700 \mathrm{MW}$ from the 17 zones and the variance areas, or enough energy to power over 7 million American homes (Table 5). ${ }^{68}$ 
Table 5. Potentially Developable BLM Land (Acres) Under PEIS ${ }^{69}$

\begin{tabular}{|l|l|}
\hline State & Potential Developable Land (Acres) \\
\hline AZ & $3,380,877$ \\
\hline CA & 766,078 \\
\hline CO & 95,128 \\
\hline NM & $4,184,520$ \\
\hline NV & $9,076,145$ \\
\hline UT & $1,809,759$ \\
\hline Total & $\mathbf{1 9 , 3 1 2 , 5 0 7}$ \\
\hline
\end{tabular}

By 2030, under a reasonably foreseeable development scenario, BLM projects a total of almost $32 \mathrm{GW}$ of installed utility-scale solar project capacity on BLM and non-BLM lands in six states (Table 6), representing approximately 3\% of existing electric capacity in the United States. Such capacity could require significant amounts of water, and BLM estimates that the total water demand for wet cooling and dry cooling for all solar projects by 2030 could total 72.1 billion and 5.8 billion gallons of water, or about 221,000 acre-feet and 18,000 acre-feet per year, respectively (Table 6).

Table 6. BLM-Estimated Megawatts of Solar Power Development by 2030 Under a Reasonably Foreseeable Development Scenario ${ }^{70}$

\begin{tabular}{|l|l|l|l|}
\hline State & $\begin{array}{l}\text { Estimated MW of } \\
\text { Capacity of } \mathbf{2 0 3 0}\end{array}$ & $\begin{array}{l}\text { Estimated Water Demand-Wet } \\
\text { Cooling (billion gallons) }\end{array}$ & $\begin{array}{l}\text { Estimated Water } \\
\text { Demand-Dry Cooling } \\
\text { (billion gallons) }\end{array}$ \\
\hline AZ & 3,232 & 7.3 & 0.6 \\
\hline CA & 20,561 & 46.7 & 3.8 \\
\hline CO & 2,925 & 6.6 & 0.5 \\
\hline NV & 2,268 & 5.2 & 0.4 \\
\hline NM & 1,111 & 2.5 & 0.2 \\
\hline UT & 1,625 & 3.7 & 0.3 \\
\hline Total & $\mathbf{3 1 , 7 2 1}$ & $\mathbf{7 2 . 1}$ & $\mathbf{5 . 8}$ \\
\hline
\end{tabular}

Before the Administration finalized the PEIS, BLM reviewed a number of formal protests that solar industry groups, environmentalists, tribes, ranchers, and counties have filed opposing various aspects of the document. The industry groups argued BLM "arbitrarily and capriciously" excluded certain lands from development based on the availability of sunlight, which they maintain has no bearing on possible environmental conflicts and errs in assuming where solar development will be commercially viable. For their part, the environmental groups raised a number of concerns that the variance areas are too sensitive for industrial development, that the plan violates federal environmental protection laws and the FLPMA, and that it should only allow development on disturbed lands, among other concerns. ${ }^{71}$ 


\subsection{Financial Considerations Impacting CSP}

CSP plants are generally more expensive than other forms of energy because they are capital intensive and require greater amounts of material and labor to construct and maintain than other forms of electricity generation. For example, as shown in Table 7, the capital costs of CSP with storage are $\$ 7,100 / \mathrm{kW}$, compared to $\$ 1,100 / \mathrm{kW}$ for a natural gas combined cycle plant and $\$ 2,900 / \mathrm{kW}$ for PV. In turn, this means that CSP has a higher LCOE at $\$ 170-\$ 290 / \mathrm{MWh}$, which is significantly higher than natural gas and PV, which have LCOEs of $\$ 50-\$ 60 / \mathrm{MWh}$ and $\$ 100$ $\$ 170 / \mathrm{MWh}$, respectively (Table 7).

Table 7. Estimates of Current Capital Costs and Levelized Cost of Electricity ${ }^{72}$

\begin{tabular}{|c|c|c|}
\hline Technology & Capital cost $(\$ / k W)$ & LCOE (\$/MWh) \\
\hline Coal Steam & 3,600 & $60-90$ \\
\hline IGCC with CCS & 8,000 & $120-180$ \\
\hline Natural Gas Combined Cycle & 1,100 & $50-60$ \\
\hline Nuclear & 7,500 & $100-160$ \\
\hline Biomass & 4,250 & $100-130$ \\
\hline Geothermal & 5,800 & $90-130$ \\
\hline Wind & 2,000 & $60-90$ \\
\hline Utility PV & 2,900 & $100-170$ \\
\hline CSP (no storage) & 4,900 & $160-270$ \\
\hline CSP (with storage) & 7,100 & $170-290$ \\
\hline
\end{tabular}

Notes: IGCC=Integrated Gasification Combined Cycle. $\mathrm{CCS}=$ Carbon Capture and Storage.

Despite higher capital costs, CSP plants can provide important, low-cost grid services during times of summer peak load. Such services and grid value are not adequately captured by LCOE metrics, which do not consider the time-varying value of electricity. ${ }^{73}$ CSP facilities can meet important peak load demands at a lower operational cost than many fossil generators, such as natural gas combustion turbines. In addition, CSP facilities can be designed with solar multiples (the solar field size as a function of the power capacity cycle) and storage capacities optimized to provide the greatest value to the grid, such that CSP with storage can displace more high-cost fossil fuel than PV systems by storing solar energy to be used at a time of higher marginal price when the sun is not shining. ${ }^{74}$ Thus, although LCOE metrics indicate CSP plants have higher costs than other technologies, they often have a higher value to the grid in terms of displacing higher-cost fossil fuels and meeting peak summer loads.

Through their construction and operations, CSP plants have the potential to provide significant economic benefits. A 2006 NREL study found that each $100 \mathrm{MW}$ of installed CSP capacity in California results in a $\$ 626$ million economic impact on California's gross state output and creates 94 permanent operations and maintenance jobs. In comparison, the report found that a combined cycle fossil fuel plant generates a $\$ 64$ million impact on gross state output and creates 56 permanent jobs per $100 \mathrm{MW}$, while a similar simple cycle fossil fuel plant generates a $\$ 47$ million impact on gross state output and creates 13 permanent jobs. Moreover, the report found 
that for CSP plants in California, there is a total direct and indirect impact of $\$ 1.40$ on gross state output for each dollar invested compared to $\$ 0.90-\$ 1.00$ for natural gas plants. ${ }^{75}$

Notwithstanding the benefits of CSP, its higher costs compared to other energy sources could impede its deployment, at least in the short-term. Natural gas in particular is becoming a more common choice for new electric generation facilities, due in part to the fact that it is less carbonintensive than other fossil fuel based generating plants, but also because new gas extraction technologies, such as hydraulic fracturing, have increased available gas supplies in the United States. This in turn has helped drive down the price of natural gas. ${ }^{76}$ According to the U.S. Energy Information Administration (EIA), natural gas prices fell from around $\$ 10$ per million BTUs in 2005 to less the $\$ 4$ in 2012, with most of the drop taking place shortly before $2010 .{ }^{77}$

CSP plants are also facing stiff competition from other renewables, particularly PV systems. Unlike CSP, PV systems convert sunlight directly into electricity and therefore require relatively little water. They can be built in less time and at a lower cost than CSP plants. ${ }^{78}$ Technological advances, increases in manufacturing scale and sophistication, and improved installation efficiencies have led to rapid declines in the cost of PV ${ }^{79}$ For example, some reports indicate that the wholesale cost of solar modules dropped 70\% between late 2009 and mid-2011 and is expected to continue to decline as PV technologies are further refined and improved as they are deployed. ${ }^{80}$

Given these price declines, current market conditions favor PV over CSP and have prompted developers to switch at least 3,000 MW previously planned CSP projects to PV in recent years. ${ }^{81}$ In 2011 alone, developers switching four major proposed CSP projects totaling 1,850 MW to PV. ${ }^{82}$ As one research analyst noted, "You can build a PV project all-in and it will cost less upfront and cost less ongoing. You will make more money on that project, and so it just makes sense to switch it." ${ }^{83}$ These factors also make it easier for developers to secure financing for PV projects. $^{84}$

The Blythe Solar Power Project in California is one notable project to convert to PV. That project had originally been planned as a 1,000 MW parabolic trough CSP plant. However, in August 2011, the project developers announced that they would use PV for the first $500 \mathrm{MW}$ phase of the project. According to one report, the estimated installed cost of the PV panels would be approximately $\$ 3.40$ watt compared to $\$ 5.79 /$ watt for the parabolic troughs. ${ }^{85}$ Subsequently, in June 2012, the project developers announced that they would convert the entire project to PV. ${ }^{86}$

The falling cost of PV has also threatened the viability of some CSP developers. For instance, Sterling Energy Systems, the developer of the Imperial Valley Solar Project, filed for bankruptcy in 2011, claiming that its CSP technology could not compete with the falling cost of PV. Moreover, Sterling's sister company Tessera Solar sold the Imperial Valley project to another developer, who has since indicated that it will change the project's technology to PV. ${ }^{87}$

Another factor to consider when comparing the costs of CSP to PV is that CSP can provide for TES while PV does not inherently include any type of storage. Incorporating six hours of TES into a CSP facility can increase capital expenditures by as much as $80 \%$, but the LCOE actually declines by $1 \%-5 \%$ because electricity generation is greater with TES. ${ }^{88}$ However, despite the 
reduction in costs for generation, the initial increase for capital expenditures could serve as a barrier to CSP developers in securing funding.

Nevertheless, given CSP's higher upfront costs, its ability to store energy may not be a sufficient justification for most developers or financial backers to select the technology over PV, at least in the short-term. In the words of one expert: "As long as there is cheap natural gas available for long-term storage, and smart grid techniques [Demand Response] filling in the short term gaps, CSP's high-energy thermal storage is a solution looking for a problem." 89

There are a number of factors that could make CSP more cost competitive as compared with other energy technologies over the long term. First, even though dry cooling can be more expensive, the cost of water in arid areas where supplies are scarce and the added time needed to secure water supplies for a wet-cooled system could theoretically exceed the cost savings provided by wet cooling technology. Some experts have also argued that wet cooling technologies for both solar and fossil fuel electricity plants are generally feasible so long as water prices are inexpensive. ${ }^{90}$ As the cost of water rises due to increasing scarcity and demands in the West, it is possible that dry-cooled plants could result in significant cost savings over wetcooled plants. ${ }^{91}$

Second, CSP is a relatively new technology and is rapidly improving. Because technologies generally improve and become cheaper as they are deployed, some experts believe that CSP construction will rebound as the technology become less expensive. For example, a 2006 NREL report projects that CSP plants installed in 2015 in California may become more competitive with, or even equal, the cost of fossil-fuel powered plants due to increased use of the technology and experience constructing CSP plants. ${ }^{92}$ However, these developments require the actual construction of CSP plants and the increasing preference of developers to rely on PV or convert CSP projects to PV could mean that CSP efficiencies are realized at a slower pace than PV. ${ }^{93}$

Third, it is possible that CSP could complement renewable energies like PV and wind.

According to a 2011 NREL report, PV is hampered by a number of factors, including: (1) variability due to the fact that it can only produce power when the sun is shining and may not provide power when demand is at its greatest; and (2) conventional power generators have limited flexibility to reduce output and accommodate variable power generation from PV. Given these two factors, the increased use of PV and wind will require greater grid flexibility to fully utilize their variable output. As found in the NREL report, it is possible that CSP projects with storage could complement and actually enable increased PV and wind use by providing solargenerated power when it is cloudy or dark. CSP can also provide greater grid flexibility by providing firm system capacity, thereby enabling greater penetration from PV and other variable generation sources, such as wind, than would otherwise be available without CSP or other source of grid flexibility services. ${ }^{94}$ As a result, an increase in PV and other variable power generation could make CSP both more useful and more valuable.

Fourth, current cost comparisons between solar and conventional sources of energy can be seen as misleading because most of the costs of solar are included in its price, while market prices do not always reflect the external costs associated with conventional fossil fuels. ${ }^{95}$ Specifically, energy producers and consumers typically do not pay the various climate and other environmental costs that some believe to be associated with fossil fuel production, leaving these 
costs (e.g., the social cost of carbon) to be paid by society and future generations. ${ }^{96,97}$ Changing perspectives about the environmental and other costs associated with non-renewable energy production could theoretically lead to increased public demand for renewable energy, such as CSP, notwithstanding its extra costs.

Fifth, federal, state, and local governments provide a range of subsidies for fossil fuel production that lower the cost of these energy sources, including but not limited to tax incentives, direct spending, and research and development funds. ${ }^{98,99}$ Additional research into the level of subsidies given for fossil fuel production as compared with renewable energy development could help provide insights to policymakers on how best to allocate subsidy funding in the future.

Sixth, the costs associated with CSP projects are largely fixed and pertain mostly to construction and operation costs rather than fuel. In contrast, the costs of a natural gas plant are tied more directly to the price of gas. Although natural gas prices are at historic lows, a number of experts believe that gas prices will eventually rise, especially if the United States becomes a net exporter of natural gas and the price of gas corresponds to global demand, as the International Energy Agency (IEA) recently predicted in a 2012 report. ${ }^{100}$ At the same time, the EIA projects that gas prices in 2035 will range from slightly over \$8/BTU to around \$4/BTU, with the range in prices being attributed to the "considerable uncertainty [that] exists regarding the size of the economically recoverable U.S. shale gas resource base and the cost of producing those resources." 101 If gas prices rise, the costs of operating power plants that rely on natural gas will inevitably rise and could make CSP more competitive. Further, uncertainty over fluctuations in the price of natural gas or other fossil fuels may increase the competitiveness of fixed-cost CSP projects.

This report does not estimate the likelihood or a specific date of competitive CSP technologies, but the six factors described above provide examples of conditions that, if one or more occurred, could facilitate more rapid deployment of CSP technologies in the Southwest.

\subsection{Access to Transmission Corridors}

Over the last quarter century, transmission development has lagged behind electricity demand. ${ }^{102}$ Thus, the absence of sufficient electric transmission capacity to areas of high renewable potential is a principal barrier to CSP development in the Southwest.

Future energy generation could include larger amounts of electricity produced from renewable energy, including CSP. Renewable energy technologies must be located in areas where resources are available, which in many cases might be far from load centers and the existing transmission system. Consequently, some experts have opined that the West's current electric transmission system is inadequate to transmit energy generated from renewable energy to meet future loads. ${ }^{103}$

Delivering CSP-powered generation and other renewable energy sources to major load centers could require the construction of long transmission lines that could cross more than one state and traverse private and federal land. Capital costs associated with constructing such lines are timesensitive and expensive and can be subject to further costs and complications due to a host of factors, including but not limited to objections over impacts to sensitive species and habitats, land acquisition, and federal and state environmental reviews. ${ }^{104}$ As one former Arizona regulator noted, it is unlikely that a CSP project developer can justify the cost needed to build a 
transmission line to a single CSP plant. ${ }^{105}$ Multiple plants in the same area are likely needed to justify the costs of building a transmission line. ${ }^{106}$

One way CSP developers have attempted to address this challenge is to site projects along transmission corridors. For example, a number of developers in California have proposed CSP projects along existing transmissions lines to connect to existing lines. However, there is little capacity left in these lines and it is uncertain whether such connections are possible. ${ }^{107}$

\subsection{Wildlife Considerations}

CSP projects have the potential to impact wildlife in a number of ways. Some of these are common to all solar technologies, whereas others are pertinent only to CSP. These impacts range from creating intense solar fields with enough solar flux to singe and kill birds to accelerated habitat loss and related impacts for land-based animals. Although these impacts may be minimal in some cases, they do have the potential to impact the suitability of possible CSP sites or increase costs for CSP developers, particularly when the affected animals are listed as threatened or endangered under the Endangered Species Act (ESA).

BrightSource Energy's Ivanpah CSP project in California provides one example of how wildlife concerns can impact a project. Located on 3,600 acres of federal land in the Mojave Desert near the California-Nevada border, the $\$ 2.2$ billion, 392-MW power tower plant was declared operational at the end of December 2013. ${ }^{108}$ The project is the largest CSP plant currently operating and uses dry cooling technology, and was designed to have a limited impact on the underlying land, with the project's heliostat pylons being inserted directly into the ground with a limited amount of grading. ${ }^{109}$ Although initial surveys found only 17 desert tortoises, which are listed as threatened under the ESA, the numbers of tortoises found during construction have been much higher and at least 166 adult and juvenile tortoises were collected and housed in holding facilities and then translocated to selected off-site areas. ${ }^{110}$ BLM issued a temporary stop-work order in April 2011 for a portion of the project site after construction activities exceeded the incidental take limit of 38 tortoises. ${ }^{111}$ Although construction has since been completed, BLM now reports that the project resulted in the relocation of adult tortoises. Additionally, some juvenile tortoises were hatched during the captivity of the females and now must be cared for by the project owner for a number of years until they are large enough to be translocated off the site $^{112}$ Tortoises outside of the project site will also be affected, primarily from the fencing and project construction which could "exclude them from and possibly destroy their home range," while also increasing tortoise density. ${ }^{113}$

Mitigating these types of impacts can delay a project, while also adding to its overall cost. For instance, BrightSource has spent \$22 million as of March 2012 caring for tortoises found on site, including funding for biologist salaries, materials to construct tortoise pens, the creation of a "head start" program for young tortoises, fencing, and other work. In addition, BrightSource expects to spend up to $\$ 34$ million meeting the project's federal and state mitigation obligations, which include tortoise habitat restoration, additional fencing, and the minimum purchase of 7,164 acres of conservation habitat - the equivalent of 2 acres for every 1 acre of development. ${ }^{114}$

Like other renewable energy developers, CSP developers could also face litigation over the possible wildlife impacts posed by their projects, as shown by a March 2012 lawsuit that three environmental groups filed against the federal government, asking it to stop construction of the 
Calico CSP solar station in San Bernardino County, California, over concerns related to the project's possible impacts on the desert tortoise, the golden eagle, and other protected wildlife. ${ }^{115}$

\subsection{Impacts to Native American Cultural Resources}

Native Americans have lived in the Southwest for thousands of years and CSP projects that disturb large amounts of land can potentially disturb Native American remains, cremation sites, artifacts, and other sensitive resources. ${ }^{116}$ As discussed in greater detail during the Genesis Solar Project case study in Section 6.2, Native American artifacts and cultural resources have been found on or near CSP construction sites, which has prompted some Native American communities to ask that large portions of certain areas be deemed off-limits for plant construction. These objections have in turn lead to the temporary suspension of construction activities in some cases, while also raising the possibility that some plants may need to be redesigned or re-sited. As with other large-scale renewable energy projects, these developments increase the overall costs of CSP projects and may make certain projects financially infeasible. 


\section{Water and Facility Permitting for CSP Plants}

States are primarily responsible for allocating the water resources within their borders and therefore oversee the administration of water rights for CSP projects. Given potential levels of CSP deployment in the Southwest and the amount of water needed to operate CSP facilities, securing water rights could play a role in determining the viability of future projects.

Most CSP plants are located in remote desert areas far from surface water sources and population centers. This means that groundwater is often the only available or economically feasible water source because municipal water supplies are often unavailable and the cost of pumping surface water or wastewater over long distances may be prohibitive. In those cases where surface water exists, such water is often already appropriated for other uses, which means that CSP developers seeking surface water must obtain a "change" or "transfer" of an existing right.

This section will discuss the water right and facility permitting processes that each of the three southwestern states uses when approving water uses for CSP projects. It begins by describing the Prior Appropriation Doctrine, which serves as the basis for many of the water right allocation decisions in the Southwest and then describes the water and facility permitting processes that Arizona, California, and Nevada use for CSP plants. Although this section is focused primarily on the water supply aspects of these processes, it does briefly describe some of the water quality aspects where appropriate.

\subsection{The Prior Appropriation Doctrine}

The prior appropriation doctrine is the predominant method states in the Southwest use to allocate and regulate the use of surface water, although some exceptions apply, particularly in California. States define and utilize this doctrine somewhat differently, but certain elements must usually exist to constitute a valid appropriation of water, namely: (1) an intent to apply the water to a "beneficial use" (e.g., energy development, agricultural, domestic, and other uses); ${ }^{117}$ (2) an actual diversion of water from its source to the place of use; and (3) timely application of the water to a beneficial use. ${ }^{118}$

One fundamental condition of an appropriative right is the principle of "first in time, first in right," in which the date a water right is established (priority date) determines who receives water in times of shortage. Under this concept, water right holders with older priority dates have a right to use their full appropriation before junior users with later priority dates. Consequently, in times of shortage, senior users will receive their full apportionment while junior users may receive no water at all. ${ }^{119}$

Another key condition is the principle of "use it or lose it," which requires water right holders to use water as prescribed or lose all or part of the right to its use through abandonment, forfeiture, or prescription. ${ }^{120}$ After water is lost, it returns to the public domain to be appropriated for another's use. ${ }^{121}$

Notwithstanding the prevalence of the prior appropriation doctrine as applied to surface waters in the Southwest, Arizona and California use different mechanisms to allocate groundwater. This is significant given that most CSP plants rely on groundwater rather than surface water. These approaches are discussed in greater detail below. 


\subsection{Arizona}

The key Arizona agencies responsible for overseeing the water-related aspects of CSP development are the Arizona Department of Water Resources (ADWR), which administers waters rights; the Arizona Department of Environmental Quality (ADEQ), overseeing water quality; and the Arizona Corporation Commission (ACC), the state's utility commission.

\subsubsection{Water Rights Permitting}

Arizona's Water Code has adopted the doctrine of prior appropriation for surface water and recognizes energy production as a beneficial use. ${ }^{122}$ However, Arizona's water system is bifurcated between surface water and groundwater, and different permitting requirements may apply depending on the water source. ${ }^{123}$ Under Arizona's Surface Water Code, a person must obtain a permit from ADWR to make a new appropriation of surface water, other than Colorado River water. As explained below, approval from ADWR is also required to sever an existing surface water right from the land to which it is appurtenant and transfer the right to a new place of use, which may include a new type of use. A person may use mainstream Colorado River water only pursuant to a right established before 1968 or a contract with the Secretary of the Interior through the U.S. Bureau of Reclamation. The use of Central Arizona Project (CAP) water requires a sub-contract with the Central Arizona Water Conservation District. ${ }^{124}$

Under Arizona's Groundwater Code, the extent to which groundwater is regulated depends on the area of the state in which the groundwater is withdrawn. The most extensive regulation occurs in the five areas of the state designated as Active Management Areas (AMA). In those areas, with certain exceptions for small non-irrigation wells, a person can withdraw groundwater only if the person holds a grandfathered groundwater right or obtains a groundwater withdrawal permit from ADWR. In all areas of the state, wells must be registered with ADWR and new well construction must comply with ADWR's well construction standards.

Effluent (treated municipal waste water) is not regulated under Arizona's statutes, except that it cannot be used to irrigate agricultural lands in an AMA or Irrigation Non-Expansion Area (INA) that were not irrigated at some time between 1975 and 1980. A person who produces effluent may use the effluent or sell it to another person. Although effluent use is not regulated by ADWR, it must be put to a reasonable and beneficial use.

Under Arizona's Underground Storage and Recovery statutes, effluent and surface water, including Colorado River Water, may be stored underground and recovered at a later date within the same AMA or groundwater basin in which it is stored. Permits from ADWR are required to construct and operate an underground storage facility and to store water at the facility. A permit from ADWR is also required to recover the water through a recovery well. Surface water, other than Colorado River water, must be recovered within the same year in which it was stored. ADWR issues long-term storage credits for the storage of effluent and, with certain exceptions, Colorado River water. A person who holds long-term storage credits may recover the stored water at any time. Long-term storage credits may be assigned to another person, with certain exceptions. 


\subsubsection{Surface Water}

The prior appropriation doctrine applies to surface water rights in Arizona, and ADWR is responsible for processing applications as appropriate. ${ }^{125}$ Currently ADWR does not have specific requirements for applications to appropriate water for CSP. However, there are specific requirements for applications to appropriate water for hydropower generation purposes, which may be a good guideline for future CSP applications. These requirements include: "the nature of the works by which power is to be developed, the pressure head and amount of water to be utilized, the points of diversion and release of the water and the uses to which the power is to be applied." ${ }^{126}$ The application must also include maps, drawings, and other specified information. ${ }^{127}$

If the CSP facility plans to build a reservoir, the application must also describe "the dimensions and description of the dam, the capacity of the reservoir for each foot in depth, the description of the land to be submerged and the uses to be made of the impounded waters." ${ }^{128}$ Moreover, such reservoirs generally must comply with the state's dam safety statutes if their storage capacity will be more than 50 acre-feet or if the height of the artificial barrier will exceed 25 feet in height, with certain exceptions. ${ }^{129}$

In reviewing applications to appropriate water for a CSP project, ADWR will consider whether the proposed water use for the CSP project "conflicts with vested rights, is a menace to public safety, or is against the interests and welfare of the public." ${ }^{130}$ Again, there are no specific requirements for CSP, but the requirements for hydropower may serve as a guideline for future CSP applications. Once ADWR grants the permit application and the water is put to beneficial use, the CSP project will be eligible to obtain a certificate for the right to use water for power development for 40 years from the application date, with a preferred right of renewal. ${ }^{131} \mathrm{In}$ addition, if the CSP project plans to generate hydroelectric energy in excess of 25,000 horsepower (18.64 MW), the project must be authorized through an act of the Arizona Legislature. ${ }^{132}$

In most areas of Arizona, un-appropriated water is unlikely to be available, and CSP plants will need to acquire existing water rights. To change the type of use and the place of use to a CSP plant for power purposes, the project developer must submit an Application to Severance and Transfer with ADWR, and the application will move through a number of administrative steps that involve public notice and the possibility of an administrative hearing. ${ }^{133}$ In addition to ensuring that the application will not impair existing water rights, ADWR will also review the application to ensure that the underlying right has been lawfully perfected and has not been forfeited or abandoned. In no event shall the water diverted or used after the transfer exceed the vested rights existing at the time of the severance and transfer. ${ }^{134}$ Of note, certain severance and transfer applications may also require approval from irrigation districts, agricultural improvement districts, or water user associations if the water right is severed or transferred from lands within such entities or within a watershed or drainage area that contributes water for the irrigation of lands within those entities. ${ }^{135}$

\subsubsection{Colorado River Water}

Different requirements apply to the use of surface water allocated to Arizona from the Colorado River. Pursuant to the Boulder Canyon Project Act (BCPA) of 1928, persons must obtain authority to use Colorado River water from the Secretary of Interior through the U.S. Bureau of Reclamation. ${ }^{136}$ ADWR will make a recommendation to the Secretary regarding the allocation of 
water from the Colorado River, including transfers of mainstream Colorado River contracts, and the Secretary makes the final decision regarding whether to approve the use after considering ADWR's recommendation. ADWR also makes recommendations to the Secretary on proposed transfers of CAP subcontracts. ${ }^{137}$ The conditions to use the Colorado River water from the CAP are contained in subcontracts between the Central Arizona Water Conservation District, the Secretary of Interior, and the subcontractor. ${ }^{138}$

\subsubsection{Groundwater Uses Within Active Management Areas}

In order to place Arizona's groundwater rights permitting process in its proper context, some background regarding the state's Groundwater Management Act (GMA) ${ }^{139}$ and AMAs is necessary. ${ }^{140}$ Arizona passed the GMA in 1980 to address groundwater overdraft in the state's most populated areas. The GMA designated four areas of the state as AMAs and established management goals for groundwater use in those areas. In 1995, one of the AMAs was divided into two AMAs, resulting in five AMAs today - the Phoenix, Pinal, Prescott, Santa Cruz and Tucson AMAs. With the exception of the Pinal AMA, the management goal for each AMA is to achieve safe yield by 2025 or to maintain a safe-yield condition. ${ }^{141}$ The statutes and rules governing water use in each AMA contain various provisions aimed at managing excessive groundwater pumping and achieving the AMA's management goal. ${ }^{142}$

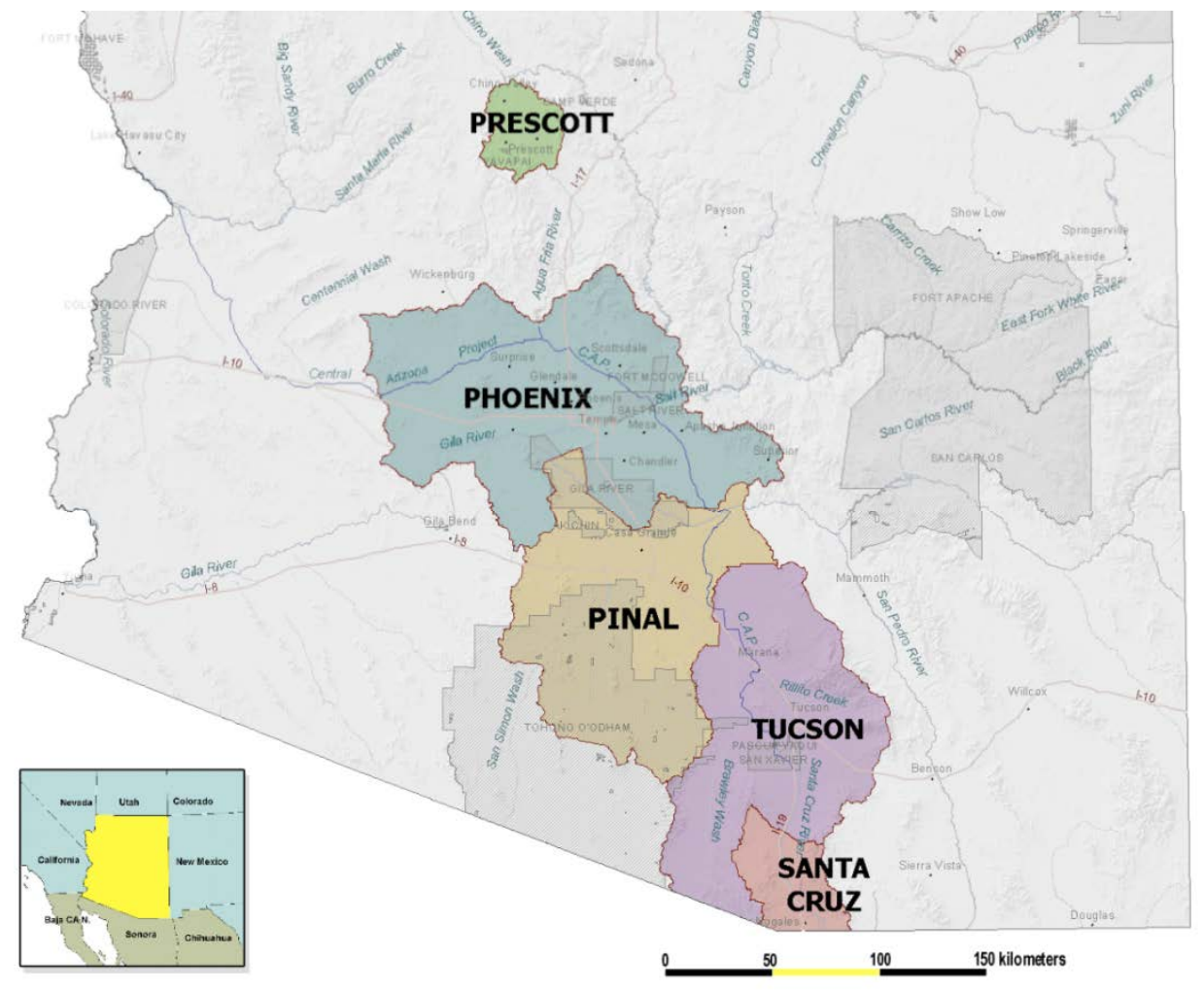

Figure 9. AMAs in Arizona ${ }^{143}$

The GMA governs groundwater use within AMAs. All wells within the state, including wells within AMAs, are required to be registered with ADWR. Entities seeking to use groundwater within an AMA from a well with a maximum pumping capacity in excess of 35 gallons per minute (gpm) must secure a groundwater right. Wells with a maximum pumping capacity of 
$35 \mathrm{gpm}$ or less are generally exempt from the requirement to obtain a water right, but a Notice of Intention to Drill (NOI) must be filed with ADWR before drilling the well. To pump groundwater from a non-exempt well in an AMA, a CSP developer must secure one of the following forms of groundwater withdrawal authority: ${ }^{144}$

- Grandfathered Groundwater Rights (GFRs):

- Irrigation GFR (IGFR): An IGFR confers the right to irrigate specific acres of land within an AMA that were irrigated at some time between 1975 and 1980. CSPs would be considered non-irrigation uses and could not legally be served by an IGFR. However, subject to certain conditions, an IGFR can be retired and converted to a Type 1 non-irrigation GFR pursuant to Section 45-469 of Arizona Revised Statutes. ${ }^{145}$

- Type 1 Non-Irrigation GFRs: A Type 1 non-irrigation GFR is associated with land that has been permanently retired from farming and converted to nonirrigation use, such as an industrial plant. As with IGFRs, a Type 1 non-irrigation GFR can only be conveyed with the underlying land and is limited to a maximum water duty of 3 acre-feet of groundwater per acre of retired farmland. ${ }^{146}$ As Figure 6 in Section 2 highlights, wet-cooled CSP projects often require around one acrefoot of water per acre per year.

- Type 2 Non-Irrigation GFRs: Type 2 non-irrigation GFRs were granted to existing commercial and industrial users of groundwater at the time of passage of the GMA. These rights can only be used for non-irrigation purposes and have a maximum volume equivalent to the maximum amount of groundwater pumped in any one year between 1975 and 1980. Type 2 non-irrigation GFRs are personal property and do not belong to the land on which the original use occurred. However, they can be used only in the AMA in which the original use occurred. They can be attached to existing non-exempt wells throughout the AMA or can serve as the withdrawal authority for a new well in the AMA, subject to approval of a well impact analysis. Any portion of a Type 2 non-irrigation GFR can be leased, but a sale of the right must include the entire right. ${ }^{147}$

- Groundwater Withdrawal Permits:

- General Industrial Use (GIU) Permit: A person can apply to ADWR for a GIU permit to pump groundwater in an AMA for a non-irrigation use from a well or wells located outside of the exterior boundaries of the service area of a city, town, or private water company. ADWR must grant the permit if the applicant demonstrates that it has been unable to secure water from all other potential sources (e.g., it does not own a GFR and does not have direct access to effluent or Central Arizona Project (CAP) water, and, if it is within 3 miles of the exterior boundaries of a municipal water provider, service has been denied by the provider) and that there is an assured water supply for the intended use at the proposed point of withdrawal for the term of the use. A GIU permit may be granted for up to 50 years and an application for renewal can be submitted and renewed under the same criteria used in granting the original permit. However, if ADWR determines that other types of water (e.g., CAP water or effluent) are 
available at a cost comparable to groundwater, it might require the GIU permittee to use such water in lieu of groundwater. ${ }^{148}$

ADWR imposes conservation requirements on groundwater uses within AMAs through a series of Management Plans. Power plants built after 1984 and that use groundwater are required to achieve 15 cycles of concentration of the recirculating cooling water before blowing down their cooling tower water. ${ }^{149}$ These requirements apply to facilities that use any amount of groundwater, but do not apply to facilities that are served entirely with surface water, including Colorado River water, effluent, or both. ${ }^{150}$

\subsubsection{Groundwater Uses Within Irrigation Non-Expansion Areas}

In addition to creating AMAs, the GMA also led to the creation of three irrigation non-expansion areas (INAs). INAs are designated areas in rural parts of the state where the irrigation of new lands is prohibited. In an INA, only acres of land that were legally irrigated at any time during the 5 years preceding the establishment of the INA may be irrigated with any water. Entities seeking to withdraw groundwater from an INA must submit an NOI to ADWR before drilling a well. ${ }^{151}$ In an INA, persons withdrawing groundwater for an irrigation use on more than 10 acres and persons withdrawing more than 10 acre-feet of groundwater per year from a non-exempt well for a non-irrigation use must install a water-measuring device on their well. All persons withdrawing groundwater from a non-exempt well in an INA, except for persons withdrawing groundwater for the irrigation of 10 or fewer acres, must file an annual water use report with ADWR. ${ }^{152}$

\subsubsection{Groundwater Uses Outside of AMAs and INAs}

Groundwater withdrawals outside of an AMA and INA do not require a permit from ADWR, but the water use must be reasonable and beneficial. ${ }^{153}$ In addition, anyone installing a well must file an NOI with ADWR before drilling the well, and the well must be drilled in compliance with ADWR's well construction standards. ${ }^{154}$

\subsubsection{Groundwater Transportation Restrictions}

With certain exceptions, the GMA prohibits the transportation of groundwater between groundwater basins outside of an AMA. ${ }^{155}$ In addition, the GMA generally prohibits the transportation of groundwater from a groundwater basin outside of an AMA into an AMA. ${ }^{156}$ There are some exceptions that would allow groundwater to be transported into an AMA from the McMullen Valley groundwater basin, the Butler Valley groundwater basin, the Big Chino sub-basin of the Verde River groundwater basin, or the Harquahala INA. However, in most cases, the exceptions are limited to uses by the state or a political subdivision of the state. ${ }^{157}$

\subsubsection{Effluent}

Under Arizona law, effluent generated by a wastewater treatment plant is owned by the entity that generates it. ${ }^{158}$ The owner may put the effluent to beneficial use, abandon it into a surface water channel, in which case it would be subject to appropriation as surface water, or convey it to another entity for beneficial use. Thus, a CSP plant can purchase effluent water from the owner before it is abandoned into a stream channel. ${ }^{159}$

Additionally, if the effluent is put to a beneficial use within an AMA, the owner would be exempt from industrial conservation requirements, as long as no groundwater is used. ${ }^{160}$ 
However, if the power plant has a generating capacity of $25 \mathrm{MW}$ or larger, the state could require wet recirculating systems with cooling towers to cycle water through the cooling loop at least 15 times before discharge. ${ }^{161}$

In lieu of direct use, effluent can be stored underground (recharged) and recovered anywhere in the same AMA or groundwater basin. Permits must be obtained from ADWR to store and recover any water, including effluent. An aquifer protection permit must also be obtained from the ADEQ in order to store effluent underground. Recovery can be within the year of storage (Annual Storage \& Recovery) ${ }^{162}$ or pursuant long-term storage credits earned in prior years. ${ }^{163}$

\subsubsection{CAP Water}

CSP developers in an AMA may be able to directly use CAP water. As with effluent, such use is exempt from compliance with mandatory industrial conservation requirements if no groundwater is used. ${ }^{164}$

Developers can also pursue underground storage and recovery of CAP water through ADWR's Underground Water Storage and Recovery Program. Storage must occur in either an Underground Storage Facility (USF) or a Groundwater Savings Facility (GSF) permitted by ADWR. If entities seeking to earn or purchase CAP storage credits are withdrawing groundwater during the year of storage, some statutory restrictions may apply to the accrual or acquisition of the CAP storage credits. Recovery Well Permits are required to legally withdraw the stored water. If the recovery is from wells located outside the area of hydrologic impact (AOI) of the USF or GSF, an impact analysis is required to ensure that the recovery of stored water does not unreasonably damage surrounding land and other water uses. In an AMA, recovery of the stored water outside of the AOI could be prohibited if the local average annual groundwater decline is 4 feet or more. ${ }^{165}$ In addition, if the stored water will be recovered within the service area of a city, town, private water company, or irrigation district, consent of the water provider would be required. ${ }^{166}$

\subsubsection{Arizona Department of Environmental Quality}

ADEQ is responsible for overseeing the water quality-related impacts associated with CSP development. In general, CSP developers will need to obtain a National Pollutant Discharge Elimination System (NPDES) permit if the plant discharges into surface waters subject to the federal Clean Water Act (CWA). Such permits are intended to ensure that discharges to surface waters do not adversely affect the quality and beneficial uses of such water. ${ }^{167}$ Arizona has delegated authority from the Environmental Protection Agency (EPA) to operate the NPDES program within its borders. Developers seeking to discharge must obtain an Arizona Pollutant Discharge Elimination System (AZPDES) permit from ADEQ. ${ }^{168}$

\subsubsection{Arizona Corporation Commission}

In addition to obtaining the necessary water rights, a CSP project may also need to obtain a Certificate of Environmental Compatibility (COEC) from the ACC. The ACC is Arizona's public utilities commission and is responsible for approving thermal, utility-scale $(<100 \mathrm{MW})$ power projects. ${ }^{169}$ Applications for a COEC are reviewed first by the ACC's Power Plant and Transmission Line Siting Committee, which consists of members appointed by the ACC and various state agencies, including ADWR and ADEQ. ${ }^{170}$ 
For plants located within the service area of a city or town in an AMA, the committee must consider "the availability of groundwater and the impact of the proposed use of groundwater on the management plan ... for the active management area." 171 In addition, ADWR's representative on the committee will typically take the lead in evaluating the plant's potential adverse impacts on the proposed water source, while the ADEQ representative will consider potential adverse impacts to water quality. Although the committee is not required to evaluate water use for plants located outside of an AMA, it generally considers water rights, water availability for the life of the power plant, and the environmental effects of groundwater pumping around the plant. The committee may also ask about planned water sources and whether alternative cooling technologies or water sources are available for plants located within and outside of AMAs and INAs. Based on this information, as well as the plant's feasibility and potential economic and environmental impacts, the committee will issue a recommended COEC. ${ }^{172}$

The ACC reviews the COEC application to balance the state's need for energy and the environmental impacts of the project, including impacts to water supply, water quality, wetlands, and ecological resources. It places the burden on the applicant to prove that the proposed water supply is sustainable and also to establish how the project will mitigate the water quality impacts, if any. Nevertheless, the ACC does not collect or review additional water data. Once the CSP project obtains the COEC, the next step is to submit an application for any necessary water rights or water use permits to ADWR and for water quality permits to ADEQ. ${ }^{173}$

\subsubsection{State Actions Regarding the Use of Water for Power Plant Cooling}

Arizona has not adopted a policy or preference prohibiting the use of wet-cooled CSP plants. However, the ACC evaluates each project on a case-by-case basis and may place additional scrutiny on new wet-cooled projects given efforts in California and Nevada to limit wet cooling within their borders. ${ }^{174}$

In addition, Arizona decision makers have discussed possible limits on wet-cooled CSP plants on at least one occasion. In 2010, former ACC Chair Kristin Mayes wrote a letter to her fellow commissioners identifying a "need to examine water use by all generation sources is also likely to be heightened by climate changes." "175 Mayes suggested that the ACC consider adopting a "moratorium" for future generation projects using wet cooling technologies or "encourage the most appropriate use of water by new concentrating solar technologies." "176 Although the ACC ultimately did not adopt such a moratorium, ${ }^{177}$ it later amended the certificate of approval for the proposed Hualapai Valley Solar project to prohibit the use of groundwater at the plant and require the use of effluent from the nearby City of Kingman or employ dry or hybrid cooling technology. ${ }^{178}$ As discussed in the case study section below, the decision marked the first time the ACC prohibited the use of groundwater for a solar power plant. ${ }^{179}$

\subsection{California}

The main agencies involved in the process of approving water rights and uses for CSP plants in California are the State Water Resources Control Board (SWRCB) and the California Energy Commission (CEC). The board is responsible for the water rights and water quality functions of the state, while CEC is the lead agency responsible for overseeing the siting of new thermal power plants $50 \mathrm{MW}$ and larger. ${ }^{180}$ 
As discussed below, the SWRCB has jurisdiction over certain types of surface waters but does not have jurisdiction over percolating groundwater. Because most CSP plants rely on percolating groundwater not subject to statewide permitting requirements, the SWRCB plays a relatively minor role in the permitting for most CSP plants in California. ${ }^{181}$ Thus, in most cases, CEC and BLM play the primary role in approving CSP projects, including the feasibility of alternative water sources and cooling technologies as well as impacts to water resources. ${ }^{182}$

\subsubsection{Water Rights}

Though not common, if a CSP project intended to use surface water, it would be required to apply for a water right permit from the SWRCB. ${ }^{183}$ Water in California falls under a number of categories: surface water, percolating groundwater, and "subterranean streams." Under California law, only certain types of surface water and subterranean streams require a permit from the SWRCB, while common law governs the remaining categories. California also recognizes power generation as a beneficial use. ${ }^{184}$

\subsubsection{Surface Water - Appropriative Rights}

California recognizes two types of appropriative surface water rights. The first, known as pre1914 rights, were developed in the early 1900s as farmers, miners, and others took control of and used the water they needed. These rights predated California's current permitting system, and the California Water Code allows the holders of such rights to change their purpose or place of use without filing an application with the SWRCB, but the change must not injure other water rights. ${ }^{185}$

The second type of appropriative water rights are known as post-1914 rights and were established after the creation of California's current permitting system under the Water Commission Act of 1914. Applicants seeking to appropriate or transfer these rights must file an application with the SWRCB, which will assess the application to ensure that it will not injure other water right holders or unreasonably affect fish, wildlife, or other instream uses. Besides the beneficial use proposed, the SWRCB will also evaluate the relative benefits derived from such use, possible water pollution, and water quality. Then, the SWRCB will subject the project to public notice and protests from interested individuals or groups. A water right permit is issued once the protests are resolved or dismissed or when the SWRCB approves the application after conducting a hearing. ${ }^{186}$

Post-1914 right holders may change the point of diversion, place of use, or purpose of use subject to the SWRCB's approval, which may include public notice and a hearing. Such transfers must not injure other water rights or unreasonably affect fish, wildlife, or other instream beneficial uses. ${ }^{187}$ In addition, surface water transfers wheeled through state or local conveyance facilities must not unreasonably affect the environment or economy of the county of origin. ${ }^{188}$ The permanent sale of a surface water right - as well as multi-year leases - is also subject to the California Environmental Quality Act (CEQA), which requires mitigation of environmental impacts. A similar review and approval process applies to temporary transfers of one year or less. ${ }^{189}$ 


\subsubsection{Surface Water - Riparian Rights}

California also recognizes riparian rights that were established prior to its recognition of prior appropriation rights. Riparian rights do not require a permit from the SWRCB. Instead, they arise from the lands adjoining the water body from which they are drawn and must be used on those lands. They cannot be transferred to another parcel of land, are not created by use or lost through non-use, and do not require permits, licenses, or government approval. ${ }^{190}$ Importantly, riparian right holders have a higher priority than appropriative rights but have the same priority amongst themselves, which means that in times of drought or water shortage, riparian right holders on the same stream must reduce their usage and share the remaining available supply according to their needs. ${ }^{191}$ Because most CSP plants are located in remote deserts far from rivers and streams, riparian rights play a minor role in CSP development.

\subsubsection{Groundwater}

The SWRCB's authority to issue permits and licenses for the appropriation of underground water only extends to "subterranean streams flowing through known and definite channels." 192 California uses the following elements to determine whether underground water qualifies as a "subterranean flow:" (1) a subsurface channel must be present; (2) the channel must have relatively impermeable bed and banks; (3) the channel course must be known or capable of being determined by reasonable inference; and (4) groundwater must be flowing in the channel. ${ }^{193}$ Underground water that satisfies these conditions are relatively rare but are subject to the same permit requirements as surface water. ${ }^{194}$

However, California does not have a statewide permitting system for underground water that does not flow in a subterranean stream, such as water percolating through a groundwater basin. Land owners have a first right to withdraw percolating groundwater for reasonable beneficial use on their overlying lands without acquiring a permit from the SWRCB. ${ }^{195}$ The right of each owner is equal and correlative to the right of other owners similarly situated, and available water supplies must be equitably apportioned among users during times of shortage. ${ }^{196}$ However, percolating groundwater use is subject to regulation in some basins pursuant to court decrees that adjudicated groundwater rights in those basins. ${ }^{197}$

\subsubsection{Effluent}

The California Water Code recognizes cooling for thermal electric power plants as a beneficial water use for wastewater. ${ }^{198}$ The SWRCB and nine Regional Water Quality Control Boards (RWQCB) oversee the water quality and quantity aspects of water reuse under the California Water Code. California permits recycled water activities from public entities and some private sources by issuing waste discharge requirements, individual water recycling requirements (WRRs), ${ }^{199}$ Master Reclamation permits, or under SWRCB's statewide general permit. The Regional Water Boards determine which type of permit to issue depending on the project type, user type, and application area. They also consult with the California Department of Public Health when issuing WRRs, which contain public-health-related requirements. ${ }^{200}$

\subsubsection{Public Trust Doctrine}

The Public Trust Doctrine sets forth the principle that certain resources that are too valuable to be owned privately and that government should maintain them for the public good. The doctrine has been most often invoked with respect to land access and use, particularly access to seashores. 
In 1983, the California Supreme Court indicated a willingness to apply the doctrine to water appropriations in National Audubon Society v. Superior Court. Also known as the "Mono Lake Case," the case focused on whether appropriative water rights should consider the public trust doctrine and addressed claims from an environmental group that water diversions for the City of Los Angeles were harming Mono Lake in violation of the doctrine. The court ruled that the lake is a public trust resource and that the doctrine "prevents any party from acquiring a vested right to appropriate water in a manner harmful to the interests protected by the public trust." ${ }^{201}$ At the same time, the court recognized that the diversions were critical to Los Angeles' water supply and ruled that the state may approve diversions that are harmful to the public trust but "must bear in mind its duty as trustee to consider the effect of the taking on the public trust... and to preserve, so far as consistent with the public interest, the uses protected by the trust." 202 Ultimately, the decision required the state to consider the public trust when administering water rights and reviewing water rights applications, finding that the doctrine and the appropriative water rights system are "parts of an integrated system of water law" and that the state has continuing "sovereign power" to protect public trust uses. ${ }^{203}$

\subsubsection{SWRCB and Regional Water Boards - Water Quality}

The SWRCB operates under authority from EPA to implement the CWA and under state authorities to protect water quality and ensure that the state's water resources are put to beneficial use. The Regional Water Boards have delegated responsibility to implement statewide water quality policies and control plans, including the establishment of waste discharge requirements (WDRs). WDRs for surface water discharges also serve as NPDES permits. The SWRCB and RWQCB have developed statewide and region-wide general NPDES permits to cover multiple facilities within a specific category. A project owner applies for coverage and reports on compliance with the requirements under these permits. The use of general permits allows the SWRCB and RWQCB's to allocate resources in a more efficient manner and provide timely coverage for large numbers of facilities in the same category. In some cases a permit specifically tailored to an individual facility is required. ${ }^{204}$

Of note, the SWRCB establishes statewide water quality policies and regulations, and the Regional Water Boards monitor and enforce state and federal plans, polices, and regulations. Each Regional Water Board also makes water quality decisions for its region in addition to issuing WDRs, including determining compliance with WDRs and taking appropriate enforcement actions. ${ }^{205}$

\subsubsection{The California Energy Commission}

CEC is California's primary energy policy and planning agency ${ }^{206}$ and plays the most prominent role in permitting most CSP projects in California. CEC has a one-stop permitting process, and its permit is in lieu of all other local, state, and federal permits to the extent allowed by federal law. CEC is responsible for the environmental review and certification of solar thermal power plants that are $50 \mathrm{MW}$ and larger under its state-certified regulatory program that incorporates CEQA ${ }^{207}$ CEQA requires state and local agencies to assess and identify the environmental impacts of their permitting actions that may require an environmental impact report (EIR). ${ }^{208}$ However, CEC's certified regulatory program exempts it from preparing a standard EIR for power plants and their associated linear facilities, such as transmission, gas, and water lines, ${ }^{209}$ but requires it to prepare a Staff Assessment (SA), which includes an analysis and documentation 
of the environmental and engineering impacts, alternatives, mitigation measures, and conditions of certification for the project. ${ }^{210}$

CEC's review process begins when the applicant files an Application for Certification (AFC). ${ }^{211}$ After CEC conducts a data adequacy review and determines the AFC to be complete, the agency has 12 months to render a final decision. ${ }^{212}$ When CEC determines that the AFC contains sufficient information, it appoints a committee of two commissioners to oversee the formal certification process, ${ }^{213}$ which involves staff conducting multiple publicly noticed workshops during its independent discovery and analysis. The staff is an independent party to the proceeding along with the applicant and any intervenors. The staff's assessment is filed as its expert sworn testimony subject to cross examination in an adjudicatory process with public participation. ${ }^{214}$ Public comments will not be considered formal evidence unless citizens and organizations become parties in the process by requesting intervenor status. ${ }^{215}$ The committee will render a Presiding Member's Proposed Decision based upon the evidentiary record and make a recommendation to the full commission. ${ }^{216}$ Once the committee submits the recommendation, the full CEC can accept, reject, or modify it at a public hearing. ${ }^{217}$

As part of this process, CEC staff will analyze a number of factors, including the effects of the project's proposed use of water on the environment and other water users, the water supply access for the plant throughout the life of the project, and the impacts on the proposed water source. ${ }^{218}$ Among other things, staff also reviews: (1) the feasibility of alternative water sources and cooling technologies; (2) the impacts on water quality and wastewater disposal; and (3) the granting of required water supply agreements. ${ }^{219}$ After such review, staff may recommend water use mitigation measures if necessary. ${ }^{220}$

In reviewing a proposed plant's water use, CEC will evaluate several sources of data, including water availability and quality data from the California Department of Water Resources, U.S. Geological Survey (USGS) streamflow data, SWRCB data on surface and groundwater quality, and computer models. CEC will also coordinate with the SWRCB and RWQCB's regarding the issuance of water quality permits. ${ }^{221}$

Because the majority of proposed CSP projects in California are on federal lands managed by BLM, such projects are subject to both CEC and BLM jurisdiction. As discussed in greater detail below, such applicants need a right-of-way grant from BLM, which means that projects sited on federal land require compliance with both CEQA and NEPA requirements. To expedite the environmental review and permitting process and avoid duplication, CEC staff and BLM entered into a memorandum of understanding in 2007 (2007 MOU) to provide a joint NEPA and CEQA review of utility-scale solar and renewable energy projects under their jurisdictions. Under the agreement, CEC plays the primary role and collaborates with BLM to ensure that NEPA requirements are satisfied. ${ }^{222}$

\subsubsection{State Actions Regarding the Use of Water for Power Plant Cooling}

The regulatory climate in California has shifted away from using freshwater sources for power plant cooling purposes to dry cooling and wastewater. In 1975, the SWRCB adopted Resolution No. 75-58 regarding the use and disposal of inland waters used for power plant cooling. The resolution encourages the use of wastewater for power plant cooling purposes and sets forth the following order of preferences: (1) wastewater being discharged to the ocean; (2) ocean water; 
(3) brackish water or irrigation return flows; (4) inland waste water of low total dissolved solids; and (5) other inland waters. The criteria for the selection of water delivery options also involves consideration of economic feasibility, engineering constraints, and environmental considerations, including impacts on groundwater levels, riparian habitat, and surface and subsurface water quality. ${ }^{223}$ The SWRCB also adopted a policy in 2010 establishing much stricter standards for new and existing power plants that use once-through cooling to protect marine life. As a result once through cooling for coastal power plants is being phased out. ${ }^{224}$ While the policy has no direct impact on CSP plants, which are generally located away from the coast, it further indicates California's shift toward dry cooling and other more water efficient cooling technologies. ${ }^{225}$

CEC reiterated certain principles from Resolution No. 75-58 as part of its 2003 Integrated Energy Policy Report, which states that it will approve the use of fresh water for cooling purposes only where alternative water supply sources, alternative cooling technologies, and "zero-liquid discharge" technologies are "environmentally undesirable" or "economically unsound." 226 As discussed in greater detail in the case study section below, the CEC committee that conducted the final review of the Genesis Solar Energy project found these and other policies had the effect of requiring groundwater-using energy projects to use the "least amount of the worst available water."227

In 2008, California and the Department of Interior formed a Renewable Energy Action Team (REAT) to facilitate permitting issues with specific renewable energy projects in California. The team consists of representatives from CEC, the California Department of Fish and Wildlife, the California Natural Resource Agency, BLM, and the U.S. Fish and Wildlife Service. ${ }^{228}$

In September 2009, REAT issued draft interim guidance for desert renewable energy project development that set forth recommended actions intended to help developers create project proposals that could be processed in an efficient and expedient manner. ${ }^{229}$ One recommendation on ways project developers could avoid delays stated: "The project will not use fresh ground water or surface water for power plant cooling." ${ }^{230}$ REAT subsequently issued a best management practices and guidance manual in 2010 that tightened up this recommendation, stating that such projects "will use air-cooling technologies for thermal power plant cooling."231 The document further stated that if this and the other recommendations were not addressed, "it is very likely that environmental review and decision-making will take additional time."232

Of further note, Secretary of the Interior Ken Salazar and Governor Arnold Schwarzenegger signed a memorandum of understanding (2009 MOU) in October 2009 that established a collaborative model in which Interior and California would work together to spur the development of environmentally appropriate renewable energy on public lands in California through expediting project review and stimulus funding from ARRA. ${ }^{233}$ Among its major provisions, the agreement builds upon REAT and sets forth a process to develop a strategy to identify suitable areas for CSP and other renewable energy development. It was also intended to prioritize application processing for solar development. ${ }^{234}$

\subsection{Nevada}

In Nevada, the major agencies involved in the water-related aspects associated with CSP projects are the State Engineer, Nevada Division of Environmental Protection (NDEP), and the Public Utilities Commission of Nevada (PUC). The State Engineer administers water rights, NDEP 
regulates water quality, and the PUC is responsible for overseeing final power plant approval for certain renewable utility facilities.

\subsubsection{Surface and Groundwater Rights}

Nevada's water law system is based on the doctrine of prior appropriation, which applies to both surface and groundwater. ${ }^{235}$ All water within Nevada's boundaries, whether above or beneath the surface of the ground, belongs to the public ${ }^{236}$ and is subject to appropriation for beneficial use. ${ }^{237}$ The Nevada Division of Water Resources, through the State Engineer, is responsible for administering and enforcing Nevada water law, including surface and groundwater. ${ }^{238}$ Of note, the majority of Nevada's in-state power generation relies on groundwater for cooling purposes. ${ }^{239}$

CSP developers seeking to appropriate new water rights must apply for surface and groundwater rights from the State Engineer. If the State Engineer determines water is available for appropriation, he will consider whether the proposed use will conflict with existing water rights or domestic wells and whether the use of the water is in the public interest. ${ }^{240}$ The permitting process to obtain surface water rights is somewhat similar to the process to obtain groundwater rights as well as the process to transfer existing surface and groundwater rights. ${ }^{241}$

For power purposes, permit applications must describe "the vertical head under which the water will be applied, the location of the proposed powerhouse, and, as near as may be, the use to which the power is to be applied." 242 The application is also limited to water for no more than one source to be used for no more than one purpose. ${ }^{243}$

Once complete, notice of the application is published in a newspaper of general circulation for approximately 30 days. ${ }^{244}$ Within 30 days after the last day of publication, interested parties may file a formal protest explaining their objections and requesting denial of the application or other appropriate actions by the State Engineer. ${ }^{245}$ After the protest period expires, the application is ready for action by the State Engineer, who has discretion to hold a hearing prior to any decision. ${ }^{246}$ If the State Engineer denies the application, the applicant may appeal the decision in the appropriate court of jurisdiction within 30 days after such denial. ${ }^{247}$ If the water permit is approved, the applicant may initiate the work to divert and use the water established as the beneficial use. ${ }^{248}$

Nevada law also authorizes the State Engineer to approve applications to use water to generate energy for export if it is in the public interest and the economic welfare of the State of Nevada and the water is put to a beneficial use. ${ }^{249}$ Also, the State Engineer has authority to require hydrological, environmental, or any other studies that it deems necessary prior to final determination of an application. ${ }^{250}$

In light of Nevada's arid climate, inter-basin transfers have been approved since $1873 .{ }^{251}$ To approve an inter-basin transfer, the State Engineer must consider: (1) whether the applicant has justified the need to import the water from another basin; (2) whether a conservation plan has been adopted and carried out; (3) whether the proposed action is environmentally sound; and (4) whether it is an appropriate long-term use that will not unduly limit the future growth and development in the basin and any other factor(s) he determines to be relevant. ${ }^{252}$ Applicants may also work with counties from which the water would be transferred to develop a plan to mitigate adverse economic impacts or to impose an annual fee on the water transferred. ${ }^{253}$ 


\subsubsection{Effluent}

Appropriation of effluent water (wastewater) for a beneficial use may be authorized ${ }^{254}$ if it is not contrary to the public health, safety, or welfare, and it does not interfere with federal obligations to deliver water of the Colorado River. ${ }^{255}$ NDEP must issue a permit for the use of treated effluent. As part of the permitting process, permittees must submit for review and approval an effluent management plan. State regulations also recognize five reuse categories for "approved uses" of treated effluent, each of which contains different requirements for bacteriological quality. ${ }^{256}$

\subsubsection{Public Utilities Commission of Nevada}

CSP developers must also obtain approval from the PUC, which oversees final power plant approval for renewable utility facilities greater than $70 \mathrm{MW}^{257}$ under the Utility Environmental Protection Act. ${ }^{258}$ Even if the CSP developer has obtained a water permit, water use could play a role in the PUC review process if mitigation actions are necessary to control the environmental effects of the plant's use of the cooling water or technologies. ${ }^{259}$ The PUC can also consider the effect of dry cooling on electricity rates. ${ }^{260}$

\subsubsection{Nevada Division of Environmental Protection}

In addition to the State Engineer and the PUC, CSP developers in Nevada may need to obtain water quality permits from the Bureau of Water Pollution Control (BWPC) within NDEP. The BWPC is responsible for protecting the quality of Nevada's waters from the discharge of pollutants. ${ }^{261}$ Nevada law defines "waters of the state" as: "[A]ll waters situated wholly or partly within or bordering upon this State, including but not limited to: all streams, lakes, ponds, impounding reservoirs, marshes, water courses, waterways, wells, springs, irrigation systems and drainage systems; and all bodies or accumulations of water, surface and underground, natural or artificial. ${ }^{262}$

With respect to surface waters, EPA has delegated responsibility to Nevada to implement the NPDES program under the CWA. Based on this authority, the BWPC is the state agency responsible for issuing NPDES permits for discharges to surface waters falling under the CWA's jurisdiction. ${ }^{263}$

In addition, BWPC operates a state groundwater discharge program for discharges that will infiltrate into the ground, as well as "zero discharge" permits where the potential for discharge exists but will likely not occur (e.g., lined ponds and tanks). BWPC will review proposed projects to ensure that they will not degrade background water quality or exceed water quality standards. ${ }^{264}$

\subsubsection{State Actions Regarding the Use of Water for Power Plant Cooling}

There appears to be a trend toward dry cooling technologies in Nevada, as evidenced by State Engineer decisions that have denied applications for wet-cooled power plants or expressed reservations over the use of groundwater for cooling purposes. ${ }^{265}$ For example, the State Engineer issued Ruling No. 5008 in 2001, which approved a limited amount of water for the construction of "realistic power generation projects, which will use water efficient, air-cooled technology, in exchange for a portion of the energy remaining in Nevada." ${ }^{266}$ 
In 2002, the State Engineer issued Ruling 5115, which addressed applications that a water district filed to appropriate groundwater. The district had intended to make any permits issued under its applications available to a party (in this case a tribe) as part of a proposed settlement agreement, which expressed the tribe's intention to build a coal-fired power plant, possibly wetcooled. The State Engineer granted one application for a reduced quantity and held the other in abeyance to study impacts on groundwater resources. In addressing the possible use of water for a possible power plant, the State Engineer commented:

Technology is available, which can produce significant amounts of electricity using air-cooled systems. This technology uses significantly less quantities of waters. The State Engineer...does not believe it is prudent to use substantial quantities of newly appropriated ground water for water-cooled power plants in one of the driest places in the nation, particularly with the uncertainty as to what quantity of water is available from the resources, if any. However, the State Engineer notes that his analysis may not be the same in the context of a change application of water rights that had previously been placed to beneficial use. [U]ntil a determination can be made as to the quantity of water available, any amount granted for appropriation must be limited.... ${ }^{267}$

The State Engineer's office has further indicated that it will likely rely on the precedents established in these rulings when determining whether to grant new water rights for solar energy plants in southern Nevada. ${ }^{268}$

Table 8. State Water Laws and Permitting Requirements in the Southwest ${ }^{269}$

\begin{tabular}{|c|c|c|c|c|}
\hline \multirow[t]{2}{*}{ State } & \multicolumn{2}{|c|}{ Type of State Water Laws } & \multicolumn{2}{|c|}{ State-Issued Water Permit Required } \\
\hline & Surface Water & Groundwater & Surface Water & Groundwater \\
\hline$A Z$ & $\begin{array}{l}\text { Prior } \\
\text { Appropriation }\end{array}$ & $\begin{array}{l}\text { Inside AMAs - GMA } \\
\text { Outside AMAs - } \\
\text { Reasonable Use }\end{array}$ & Yes & $\begin{array}{l}\text { Inside AMA - Yes } \\
\text { Outside AMA - No }\end{array}$ \\
\hline CA & $\begin{array}{l}\text { Prior } \\
\text { Appropriation and } \\
\text { Riparian Rights }\end{array}$ & Correlative Rights & $\begin{array}{l}\text { Pre - } 1914 \text { Prior } \\
\text { Appropriation Rights - No } \\
\text { to Transfer Right } \\
\text { Post-1914 Prior } \\
\text { Appropriation Rights - Yes } \\
\text { Riparian Rights - No }\end{array}$ & $\begin{array}{l}\text { Percolating } \\
\text { Groundwater - No } \\
\text { Subterranean Flow - } \\
\text { Yes }\end{array}$ \\
\hline NV & $\begin{array}{l}\text { Prior } \\
\text { Appropriation }\end{array}$ & Prior Appropriation & Yes & Yes \\
\hline
\end{tabular}

Notes: AMA=Active Management Area. GMA=Groundwater Management Act. 


\section{Water Issues Associated with CSP Development}

Water has played and will continue to play a critical role in determining the feasibility and profitability of CSP development in the Southwest. Physical and legal access to at least some amount of water is an essential requirement for every CSP plant. CSP development in the Southwest is also complicated by differing planning horizons, geographic boundaries, and planning requirements from the management of energy and water sectors.

CSP plants require significant amounts of space and ample sunshine, which often means that the most suitable locations are in remote, desert areas far from large population centers. The siting of these projects in such areas typically makes connecting to municipal, industrial, or wastewater supplies prohibitively expensive, which typically leaves groundwater as the only feasible water supply for such projects. However, given increasing demands for freshwater supplies in the Southwest, acquiring the right to use groundwater or other water sources for CSP plants, especially for cooling purposes, can be an expensive, time-consuming, and sometimes contentious process that has the potential to significantly delay or even scuttle projects.

This section identifies and discusses the key water-related issues, challenges, regulations, policies, and related impacts associated with CSP development in the Southwest, with a particular focus on how water can affect the siting of CSP plants.

\subsection{The Suitability of CSP in Water Scarce Areas}

One of the most significant challenges associated with CSP development in the Southwest is that those areas with the most consistent and direct sunlight are also some of the most water scarce regions in the country. ${ }^{270}$ This scarcity represents one of the principal considerations that impact the siting of CSP projects and creates a significant amount of uncertainty about the future rate and deployment of CSP development. ${ }^{271}$

\subsubsection{Water Supply Issues}

The current trend for CSP development in the Southwest appears to favor technologies and projects that strive to minimize freshwater requirements. ${ }^{272}$ Nevertheless, all CSP development requires water to some degree, and the cumulative impacts of these projects have the potential to affect water resources. ${ }^{273}$

In many cases, CSP plants have been constructed or proposed on retired agricultural land. In cases where plants are built on previously irrigated land, such plants may use less water than the previous agricultural use. For example, Abengoa Solar's 250 MW Solana Project in Gila Bend, Arizona, is built on previously irrigated farmland and uses groundwater for wet cooling. ${ }^{274}$ However, the project is estimated to consume $75 \%-85 \%$ less water per acre than the nearby alfalfa activities. ${ }^{275}$

At the same time, some policymakers have expressed concerns about using wet cooling for CSP development in light of long-term drought and increasing water demands when less waterintensive technologies are available. Former Arizona Senator Jon Kyl expressed this sentiment in a May 2010 report on CSP development in his state: 
[P]olicymakers should ask whether a wet-cooled CSP plant makes sense from a state-wide water management perspective, not whether a wet-cooled CSP plant uses less water than another very water-intensive use on a specific parcel of land. This is especially true since other technology is available such as dry or hybrid cooling that uses a fraction of the water used in wet cooling. ${ }^{276}$

Another water supply consideration pertains to the virtual export of water supplies when electricity generated in one state is exported to another. Such is the case in Arizona, which has historically produced more electricity than it consumes. According to one report, the state exports electricity that consumes about 52,000 acre-feet of water each year to generate and imports electricity that consumes 22,000 acre-feet per year. ${ }^{277}$ This creates a net loss from energy production of about 30,000 acre-feet per year, enough to supply water to 120,000 people at current water usage rates in Arizona. ${ }^{278}$

Future CSP development in Arizona and Nevada has the potential to increase electricity exports, particularly exports to California, effectively increasing the amount of water exported from these states. ${ }^{279}$ This has led some policymakers, including Senator Kyl, to question whether it is in the state's best interest to place additional demands on the state's scarce resources to export energy to other states with greater demands, especially if those states would likely prohibit wet-cooled CSP plants. ${ }^{280}$

There is also the question of sustainability. In California for example there are many groundwater basins in the desert where the storage and balance of water is poorly understood. Long term studies of natural recharge, underflow to and from basins, and the dependency of other users and natural resources on groundwater are not available. Where groundwater use is planned in a poorly understood basin various impacts could occur such as overdraft, subsidence, water quality degradation, and local impacts to other users. In some basins these impacts are already occurring. Without adequate data, estimates of basin balance and aquifer characteristics are subject to significant variability and much debate. Often times BLM and CEC must take relatively conservative approaches to evaluating potential impacts because it is not clearly known to what extent they may occur. ${ }^{281}$

Taken together, these concerns could place additional pressure on state lawmakers and policymakers to address the use of wet cooling through legislation, policies, or guidance that restrict or limit the use of wet cooling for new power plants. As mentioned previously, California has already adopted a policy limiting the use of wet cooling for new power projects.

Implementation of this policy in recent cases has resulted in only one project being licensed to use groundwater for cooling while all others are dry-cooled or limited hybrid cooling. Recent decisions by the ACC in Arizona and the State Engineer in Nevada have denied applications for wet-cooled plants.

Even without formal requirements limiting the use of wet cooling, state permitting agencies and the public will likely place increasing scrutiny on the water uses of future CSP plants given increasing water demands, drought, and other factors impacting water resources in the Southwest. 


\subsubsection{Water Rights}

As with any new water use, CSP projects have the potential to impair existing water rights, which can pose a number of obstacles in obtaining the necessary rights for projects. Given the relative scarcity of water in the Southwest, many suitable areas for CSP are located in overappropriated basins where there is no reasonable expectation of acquiring new water rights for CSP or any other use. This means that CSP projects will likely need to acquire the water they need through the purchase or lease of existing water rights. However, the ability of CSP projects to transfer water rights may be constrained in some areas. ${ }^{282}$

The Amargosa Valley in Nevada is one example of an area where these types of restrictions have occurred. In 2007, the Nevada State Engineer ruled that the Amargosa Desert basin was overappropriated by about 18,000 acre-feet per year and that applications for new water rights would be denied to avoid impairment to existing water rights. ${ }^{283}$ Nevertheless, a number of solar energy projects with a total water demand of 50,000 acre-feet per year had been proposed for the area, while only about 7,000 acre-feet of water was theoretically available for purchase or lease in the basin. ${ }^{284}$ The Nevada State Engineer found in 2008 that with few exceptions, it would deny applications to change the point of diversion of an existing groundwater right within a specific portion of the basin. ${ }^{285}$

\subsubsection{Water Transfers}

The majority of existing water rights in the Southwest are held by agricultural users, which means that water is often transferred out of agriculture for other uses, such as residential development and energy generation, when unappropriated water supplies are unavailable. In some cases, CSP developers may purchase private farm land and the associated water rights used to irrigate that land. In other cases, the water may be transferred from another location. Under either scenario, water is removed from agriculture, which raises questions about the possible impacts of CSP development (along with any other new proposed use of water) on agricultural communities and economies.

On one hand, CSP projects can provide significant economic benefits both to the local economy and to a larger state economy, as discussed in Section 3.4. Nevertheless, reducing the amount of water used for agriculture can create a number of real or perceived adverse impacts for local economies, particularly those that are heavily dependent upon agriculture. Although the permanent jobs that CSP plants create can offset decreases in agricultural workforces, the two industries require different skill sets and individuals whose employment is displaced by a transfer of water may not be qualified to work at a CSP plant. Moreover, some experts have expressed concern that displacing agriculture with energy projects poses a risk that project owners will export profits outside of the impacted community. In contrast to CSP, local agriculture is often considered to form the foundation of an area's employment and way of life and might be considered more likely to re-inject its profits into the local economy. ${ }^{286}$

Such challenges associated with water transfers away from agriculture are not unique to CSP development, and must be addressed by any new proposed use of water in many agricultural regions of the Southwest. Water transfer decisions can vary greatly by location, and could be affected by how long the land is likely to remain in agriculture over the time horizon of the project, other competing water uses for the land, relative economic productivity of existing and 
proposed land and water uses, as well as the existing degree of local control of the land and water rights.

\subsubsection{Use of Effluent for Cooling}

Effluent from municipal wastewater treatment plants represents a relatively reliable source of cooling water for CSP plants. If a CSP project is located near a population center, relying on municipal effluent may be one way of avoiding many of the social and environmental impacts associated with the use of freshwater supplies for cooling purposes. However, many CSP plants are located in areas far from population centers, which can make connecting to wastewater treatment plants cost prohibitive. ${ }^{287}$

\subsubsection{Water Quality}

CSP projects also have the potential to impact water quality, especially as water quality and quantity are connected. Depleting surface or groundwater sources for CSP project construction and operation can increase the concentration of sediments and other pollutants in surface waters. The construction activities and grading associated with developing a CSP site, which can cover large areas, have the potential to cause erosion and runoff and to alter natural drainage patterns. The application of chemical herbicides to clear sites before a project's construction can also contaminate aquifers and other water sources. The impacts on water quality of potential chemicals utilized for mirror cleaning or from inadequately constructed evaporation ponds for cooling tower blowdown water have not yet been studied in detail. Improperly installed or maintained groundwater wells needed to supply water to CSP projects can serve as conduits for pollutants that could contaminate aquifers. ${ }^{288}$ When a project uses wet cooling it often includes the use of evaporation basins to concentrate the salts from blowdown. These ponds can be detrimental to wildlife and can leak and contaminate groundwater. Parabolic trough systems also use heat transfer fluid which can leak and be a source of contamination. In California extensive monitoring programs are required to ensure that no impacts occur. ${ }^{289}$

\subsubsection{Water-Related Environmental Impacts}

In addition to impacting human uses, depleted water supplies that result from CSP development can decrease biological diversity and displace wildlife by reducing vegetation and drinking water supplies. These results could also increase the risk of wildfire as well as the susceptibility of wildlife to predation and disease. ${ }^{290}$

Jonathan Jarvis, the Regional Director of the Pacific West Region of the National Park Service, expressed similar concerns regarding the water impacts of proposed CSP projects on BLM land on natural resources in various National Park Service units in southern Nevada. In a 2009 letter to BLM, Jarvis stated that increased water demand from wet-cooled CSP plants could strain already limited water resources and "cause additional impacts to other sensitive, water-dependent natural resources associated with these park units." ${ }^{291}$ Jarvis also suggested that "energy policy managers, energy developers, federal and state land management agencies, and local communities need to discuss and recognize the natural resource constraints that will determine the success or failure of solar energy development projects in southern Nevada and plan accordingly." ${ }^{292}$ 


\subsubsection{Public Opinion and Perception}

Public opinion and perception regarding a CSP project's water use have the potential to influence siting decisions, particularly with respect to wet-cooled projects located near population or agricultural centers. However, according to many of the experts interviewed for this report, public opinion regarding the water impacts of CSP sites located in remote areas has generally been less significant than concerns associated with impacts to wildlife and cultural and historical resources. This is due in part to the fact that these types of projects are located far from population centers or agricultural areas where their water use would have an impact on other human activities. The sources interviewed for this report also indicated that the public appears to have less concern with the water use aspects of CSP projects that rely on dry cooling technology, effluent, or are sited on previously irrigated land and use less water than the prior use. ${ }^{293}$

\subsection{State Actions Expressing a Preference for Alternative Cooling Technologies}

As discussed above, recent policies and permitting decisions in the Southwest have indicated an increasing preference for alternative cooling technologies, including dry cooling and hybrid cooling. For example, of the 24 CSP plants that are operational in the Southwest, no less than 15 are wet-cooled. In contrast, of the 13 CSP projects that are under construction or development in the region, at least eight will be dry- or hybrid-cooled, while another project will use reclaimed water (Appendix).

The preference for alternative cooling technologies is particularly pronounced in California where most CSP plants and other power plants that have secured CEC approval have relied on dry cooling technology or relied on wet-cooled systems that use alternative water sources, such as wastewater. In addition, no CEC-approved plant in the last 15 years has used once-through cooling, while CEC has engaged in substantial research efforts regarding the use and possible effects of using dry cooling technologies. ${ }^{294}$

As mentioned previously, the Nevada State Engineer has also expressed concerns about wetcooled technology. Consequently, it is likely that wet-cooled CSP plants will experience additional scrutiny and increasing difficulty in securing state approval in California and Nevada.

Arizona has not adopted a state-wide policy prohibiting wet cooling due in part to concerns that dry cooling is too inefficient and costly given the state's high temperatures. However, ACC commissioners have required dry cooling in at least one CSP permitting decision, as shown by its decision requiring dry or hybrid cooling and the use of effluent for the Hualapai project. Thus, it is possible that the ACC and other Arizona policymakers could consider broader policies regarding the use of wet cooling for CSP development in the future, especially if water shortages in the state become more acute. ${ }^{295}$

\subsection{Notable Federal Water-Related Laws and Policies Regarding CSP}

Although states are primarily responsible for allocating water rights, there are a number of federal laws and regulations that impact how water is used for CSP development, particularly for plants located on federal land. This section describes key federal laws and regulations that may impact the use of water as it relates to CSP development in the Southwest. 


\subsubsection{BLM Right-of-Way Review Procedures}

As described in Section 3.3.1, BLM approves rights-of-way for CSP projects on federal land pursuant to the FLPMA, which requires consideration of impacts to environmental resources, including water. ${ }^{296}$ BLM also complied with the FLPMA in carrying out its "fast-track" right-ofway approval process, which provides a number of examples of how the agency addresses waterrelated impacts associated with CSP development.

For example, to address water quantity issues associated with CSP development, BLM required a variety of conditions for its right-of-way approvals. In some instances, it altered a project's technical components, such as limiting the number of heliostats that require washing to save water, and required project applicants to purchase water or a specific amount of existing water rights to offset the project's water use. BLM also required or encouraged applicants to use dry cooling or PV alternatives. ${ }^{297}$

Notably, BLM's right-of-way approval for the Amargosa Farm Road Solar Project in Nevada found that the environmentally preferable alternative required the use of dry cooling, stating that this alternative "... allows for the least amount of water use among the...proposed alternatives. ${ }^{" 298}$ BLM also based its decision to approve the right-of-way on the project applicant's agreement to acquire 236 acre-feet of water per year to mitigate any potential impacts of the project's groundwater withdrawals on the nearby Devil's Hole Unit of Death Valley National Park and the Ash Meadows National Wildlife Refuge. ${ }^{299}$ Of note, the project's developers switched the plant to PV in 2011. ${ }^{300}$

Certain BLM decisions have also addressed various CSP-related water quality impacts. For instance, some required the construction of drainage structures to mitigate stormwater runoff, as well as the use of best management practices to minimize soil erosion and sediment transportation. ${ }^{301}$ Of note, the agency has rejected proposals to redirect surface water in at least one case. ${ }^{302}$

\subsubsection{Water-Related Aspects of BLM's Solar PEIS}

BLM's July 2012 PEIS identifies a number of proposed design features and actions intended to avoid, minimize, and/or mitigate the potential impacts of utility-scale solar development on water resources. These include actions by the project developer to coordinate with BLM and other federal, state, and local agencies early in the planning process to identify and minimize water use for the project and to secure the necessary water rights, including consideration of water conservation measures, such as dry cooling and the use of recycled or impaired water. Other examples of water-related measures include efforts by the project developer to: (1) control project site drainage, erosion, and sedimentation related to stormwater runoff; (2) conduct hydrologic studies that demonstrate a clear understanding of the local surface water and groundwater hydrology; (3) avoid, minimize, and mitigate impacts on groundwater and surface water in accordance with the CWA and other specified environmental regulations and policies; (4) maintain water resources design elements during operations and maintenance of the project, including various monitoring activities; and (5) reclaim the project site after decommissioning to reduce impacts to water resources. ${ }^{303}$ 


\subsubsection{The Clean Water Act}

A number of provisions of the federal CWA may apply to CSP projects. In particular, the construction of CSP plants often involves the grading and clearing of significant amounts of land, which can create drainage, erosion, and sedimentation issues related to stormwater runoff. If the runoff discharges to surface waters that fall under the CWA's jurisdiction, such runoff can qualify as a point source of pollution requiring an NPDES permit under Section 402 of the CWA. ${ }^{304}$ Arizona, California, and Nevada are each authorized to administer their own NPDES programs, and developers must work with the appropriate agency in those states to secure the necessary permits.

CSP plant construction may also involve or require the discharge of fill material into surface waters subject to the CWA. In such cases, CSP developers may need to obtain permits from the U.S. Army Corps of Engineers under Section 404 of the CWA. ${ }^{305}$

Moreover, CSP plants that discharge wastewater from cooling or other purposes to surface waters will require an NPDES permit under the CWA. ${ }^{306}$ However, it is important to note that many plants may be located in areas without a suitable receiving water body. Plants located closer to population centers may also be able to discharge to a wastewater treatment plant. However, given the remote location of some CSP plants, the most feasible option for the discharge of wastewater may involve deep well injection or discharge to evaporation ponds. ${ }^{307}$

\subsubsection{The Endangered Species Act}

The purpose of the Endangered Species Act (ESA) is to conserve and restore species that the federal government has listed as either endangered or threatened, as well as the habitats upon which such species depend. Section 7 of the ESA requires that federal agencies, including BLM, ensure that their actions will not jeopardize the existence of a listed species or adversely modify its critical habitat. Section 9 of the ESA also prohibits and person from "taking" a listed species, regardless of whether the species is located on federal land. ${ }^{308}$

The ESA has the potential to impact the siting of solar projects in the Southwest because the area is home to a number of threatened or endangered species. Although BLM has indicated that it will not allow solar development in designated critical habitats, only about $12 \%$ of listed species currently have designated critical habitat. Therefore, it is likely that some areas authorized for solar development may have listed species, which may not be discovered until after a site is selected and project is underway, possibly resulting in significant delays and cost increases as projects are re-designed or modified to mitigate or minimize damages to listed species. ${ }^{309}$

With respect to water, groundwater pumping for CSP plants can impact threatened species by placing additional strain upon aquifers and other water sources that provide habitat for listed species. For example, the National Park Service had expressed concern in 2009 about proposed CSP plants in Nevada that it felt threatened Devils Hole, a detached unit of the Death Valley National Park that includes an aquifer-fed spring that provides habitat for the endangered Devils Hole Pupfish. ${ }^{310}$

\subsubsection{Colorado River Issues}

The Colorado River Compact, the BCPA, and other laws that make up the "Law of the River" may place additional restrictions on CSP plants that withdraw groundwater near the river in the 
Lower Colorado Basin, which includes Arizona, California, and Nevada. Specifically, under Section 5 of the BCPA ${ }^{311}$ and the U.S. Supreme Court's 2006 Consolidated Decree in Arizona $v$. California, ${ }^{312}$ wells in the Lower Basin that yield groundwater replaced with Colorado River water must be included in the accounting for consumptive use of the River's water and require an entitlement for diversion from the river. ${ }^{313}$

An entitlement to use Colorado River water is an authorization to put River water to a beneficial use pursuant to a contract with the Secretary of the Interior, also known as a BCPA Section 5 contract. ${ }^{314}$ For example, in California, the Secretary has contracts with specific water agencies, such as the Metropolitan Water District of Southern California. ${ }^{315}$ Entitlements can also include a reservation of water by the Secretary or a right decreed by the U.S. Supreme Court. ${ }^{316}$

In California, no additional water is available for new CSP or other energy projects unless they are through the contract of an existing BCPA Section 5 contract holder, either by direct service or through the exchange of non-Colorado River water for Colorado River water. ${ }^{317}$ Acquiring the rights to use water through an existing BCPA Section contract or exchanging non-Colorado River water may require significant costs and time that could possibly delay a project and increase its overall costs.

The Bureau of Reclamation is responsible for determining whether a well will pump water that will be replaced with Colorado River water. In general, wells located in the Colorado River flood plain are presumed to pump river water. Wells located outside of the flood plain may also be considered to pump river water if they satisfy certain conditions. ${ }^{318}$

To determine if wells outside of the floodplain will result in a consumptive use of mainstream water from the River, Reclamation has proposed an "accounting surface methodology" that the USGS developed in the 1990s. Under this method, a well located outside of the flood plain will withdraw Colorado River Water and therefore require an entitlement if: (1) it is located within the Colorado River Aquifer; and (2) the elevation of the static water level of the well is below the accounting surface of the aquifer. ${ }^{319}$ Reclamation proposed the method as a possible rule in 2008 but since withdrew the proposal and is preparing a new rule. Nevertheless, Reclamation has used the method as a tool to determine whether wells will result in consumptive use of Colorado River water, ${ }^{320}$ although other state and federal agencies have questioned whether the methodology imposes any binding requirements because it has yet to be promulgated as a final rule. ${ }^{321}$

\subsection{Water-Related Financial Considerations}

Water has the potential to impact the financial feasibility and competitiveness of CSP development in the Southwest. Although CSP plants have historically been more capital intensive and therefore more expensive than conventional power plants to build and operate, ${ }^{322}$ CSP plants that rely on dry-cooled technology tend to be even more costly than their wet-cooled counterparts. For instance, some reports indicating that the capital costs of a dry-cooled system are three times larger than a wet-cooled system. ${ }^{323}$

As mentioned in Section 2.5, dry-cooled CSP plants result in lower thermal efficiency, particularly on hot days and in warm climates, which are when and where peak power is typically most needed. ${ }^{324}$ However, these increased operational costs vary considerably and may often be relatively minor. For instance, one study of a parabolic trough plant in the Mojave 
Desert found that dry cooling was $5 \%$ less efficient than wet cooling on an annual basis, which increased the cost of the electricity the plant produced by $7 \%-9 \%{ }^{325}$ However, these results are not uniform and vary according to location, as shown by another study that found that dry cooling for a parabolic trough in New Mexico would only increase the cost of electricity by $2 \%$ because the maximum temperatures at the site were considerably lower than in the Mojave. ${ }^{326}$ Thus, while there is a performance penalty for dry cooling, the amount of this penalty varies, and it is possible that the actual penalty may be negligible in some circumstances.

The performance penalties associated with dry cooling also vary according to the type of technology used. For example, one study found that the annual electric output for a dry-cooled parabolic trough plant dropped by $4.6 \%$ compared to a wet-cooled plant, while the output of a similar power tower dropped only $1.3 \% .{ }^{327}$ The study also looked at the difference in efficiencies between the two plants during the hottest $1 \%$ of operating hours, finding that the trough plant experienced a $17.6 \%$ drop in performance compared to a $6.3 \%$ drop in performance by the power tower plant. ${ }^{328}$ If electricity prices are high during those periods, the financial impact could be substantial, ${ }^{329}$ although it may be possible to offset impacts to net electricity generation by utilizing larger solar collection fields. ${ }^{330}$ Nevertheless, increasing the solar field also increases the physical footprint of the plant, which can have other environmental and social impacts.

Hybrid cooling offers one way to address the cost issues associated with dry cooling. As mentioned previously, these systems use a combination of wet and dry cooling to reduce water consumption. One DOE study showed that hybrid cooling for a parabolic trough CSP plant that used $50 \%$ less water would result in a $1 \%$ drop in annual electrical energy output, while using $85 \%$ less water would result in a $3 \%$ drop in output. ${ }^{331}$ The performance penalties for hybrid cooling vary according to the type of CSP technology, with technologies that have lower operating temperatures experiencing higher penalties and plants with higher temperatures having lower penalties. ${ }^{332}$

In sum, although it is possible that dry-cooled or hybrid cooling technology may increase the costs of a CSP project, the resulting performance penalty may be relatively minor depending on the specific circumstances surrounding the project. Given the increasing preference in the Southwest for dry cooling, it is also likely that such CSP plants will be competitive with other CSP plants. However, the larger question pertains to whether the extra costs associated with dry cooling and hybrid cooling will hinder CSP development compared to other, cheaper energy sources. 


\section{Case Studies}

To illustrate how water affects CSP development in the Southwest, this section will describe the role it played in the approval or operation of three CSP projects, one in each of the following states: Arizona, California, and Nevada.

The projects were selected with the intention of providing a collective picture of the various water-related issues, cooling technologies, and approaches currently associated with CSP development.

\subsection{Arizona - The Hualapai Valley Solar Project}

The proposed 340-MW parabolic trough Hualapai Valley Solar Project in Mohave County, Arizona, illustrates some of the ways in which public opinion and concerns over water use can impact a project's design and ultimate approval. ${ }^{333}$

\subsubsection{Proposed Water Use}

The Hualapai project is located over 27 miles north of Kingman, Arizona, (population 28,068) and 100 miles south of Las Vegas on approximately 4,000 acres of raw, undeveloped private land. It was originally proposed as a wet-cooled plant that would require 3,000 acre-feet of water per year for all uses, of which 2,400 acre-feet would be pumped from the Hualapai Valley Aquifer for cooling purposes. Notably, the proposed site is not located within an AMA and therefore did not require the acquisition of a groundwater right from ADWR. Although the proposed project site had not been irrigated, the land had previously been designated for agricultural purposes, which could have consumed over 20,000 acre-feet of groundwater per year, according to some estimates. ${ }^{334}$

The project's developer Hualapai Valley Solar LLC (HVS) based its decision to rely on wet cooling instead of hybrid or dry cooling on concerns that the desert's high ambient temperatures would hinder the effectiveness of any dry cooling system in the area, arguing that temperatures over $100^{\circ} \mathrm{F}$ could result in output reductions of over $20 \%$ and that dry cooling would result in an additional cost between $7 \%$ and $9 \%$. HVS also expressed concern that a hybrid system would be twice as expensive as a basic wet cooling system but would still require wet cooling for half of the year when temperatures were high. ${ }^{335}$

To minimize the project's groundwater usage, HVS sought an agreement to purchase treated wastewater from Kingman and then pipe it to the project site to reduce the plant's water usage. At the time of HVS's proposal, the city's treatment plant was capable of producing 1,600 acrefeet of water per year. Initial negotiations between HVS and the city centered on a possible 10year contract to provide 900,000 gallons of $A+$ effluent per day at $\$ 0.64$ per thousand gallons (1,008 acre-feet per year), with the possibility of renewal every 5 years after $2020 .{ }^{336}$ The city also estimated that its treatment plant would produce around 2,300 acre-feet per year by $2016^{337}$ and hoped to be able to eventually supply all of the plant's water as the city's population grows and its sewer system expands to connect residents currently relying on septic systems. ${ }^{338}$

\subsubsection{Impacts to State and Local Economies}

As initially proposed, the project would have cost around $\$ 2$ billion, and HVS estimated that the project would provide $\$ 20$ million in county and state tax revenues each year, while also 
generating 1,500 construction jobs at peak construction, with 107 permanent positions created upon the plant's completion. ${ }^{339}$ HVS had intended to finance part of the project with DOE loan guarantees and intended to secure a purchase power agreement with Nevada Energy to provide energy to Nevada. ${ }^{340}$

\subsubsection{Public Opposition and Support}

In November 2009, HVS filed an application for a COEC with the ACC, which generated a significant amount of support and opposition, much of which focused on water. Those concerned about the project generally supported solar energy development but opposed the project's use of wet cooling technology due to concerns about possible impacts on local water resources. In particular, opponents argued that the Hualapai Valley Aquifer is in a state of depletion and that the project would de-water local wells, citing estimates that current depletions total 10,000 acrefeet per year while recharge is between 2,000 and 2,400 acre-feet. Although opponents generally supported the project's proposed use of effluent use for cooling, they expressed concern over whether HVS would be able to finalize an agreement with Kingman and would ultimately need to rely on groundwater to satisfy all of its cooling needs. Many opponents also argued that the plant should be dry-cooled, noting that similar CSP plants proposed for other parts of the Southwest would rely on dry cooling and would therefore have the same competitive posture.

Conversely, HVS cited groundwater models and studies that indicated that there was sufficient available groundwater for the project without impacting other groundwater users. HVS further argued that wet cooling was appropriate because both groundwater and effluent were available, unlike other CSP plants in the Southwest, and that dry and hybrid cooling would represent an unnecessary and significant cost increase that would put the project at a disadvantage with other approved wet-cooled power plants in the region. ${ }^{341}$ Project supporters, including the Mayor of Kingman, other city officials, the Kingman Downtown Merchants Association, and the Kingman/Golden Valley Association of Realtors, argued that the project would provide significant contributions to the local economy. ${ }^{342}$

\subsubsection{ACC Provisional Approval of Project}

In April 2010, the ACC granted a provisional COEC that approved the project as being in the public interest and found that its "contribution to meeting the need for an adequate, economical and reliable supply of renewable electric power" outweighed its environmental impacts. With respect to water, the certificate limited the total water use for the project to 3,000 acre-feet per year from all sources and to 2,400 acre-feet of groundwater per year for cooling purposes. Condition No. 4 of certificate also required HVS to "make all reasonable efforts" to minimize the use of groundwater during the construction and operation of the project, and to use effluent for cooling and all other non-potable water uses "to the extent it is made available by the City of Kingman... and can be transported at [HVS'] expense to the Project site." Moreover, Condition No. 4 gave HVS 2 years to enter into a contract with Kingman to supply effluent to the project and authorized the plant to use groundwater when effluent was not available from Kingman or when transmission from the treatment plant to the project site is interrupted. ${ }^{343}$

\subsubsection{Public Reaction to ACC Provisional Approval}

Opponents objected to the provisional certificate, arguing that Condition No. 4 did not provide a failsafe means of ensuring that the project would use effluent because it only required HVS to 
make a "reasonable effort" to minimize groundwater use and only mandated the use of effluent to the extent that it is available from Kingman's treatment plant. Some members of the community also expressed concerns about the possibility that Kingman's projected population growth may not take place, which would mean that the city's treatment plant would not be able to provide all of the cooling water needed for the plant. Thus, to the extent that effluent was not available, opponents argued that the ACC should require HVS to use dry cooling technology. ${ }^{344}$

Conversely, HVS argued that Condition No. 4 was sufficient, noting that the condition needed to be flexible in order to ensure that HVS was "not at the mercy of contingencies beyond its control." Namely, HVS argued that it would have no way of influencing how much effluent Kingman's treatment plant would produce or when it operates because it did not own the facility. HVS also responded to arguments that the ACC should require HVS to use only effluent for its wet cooling needs, expressing concern that such a requirement could result in situations where the plant could shut down if it did not receive enough effluent for its cooling needs. ${ }^{345} \mathrm{HVS}$ further noted in an August 2010 pleading that its negotiations for a power purchase agreement and construction contract were based on the project using wet cooling and that requiring the project to use dry or hybrid cooling "would cause serious problems with obtaining financing, primarily because there are no utility-scale solar thermal dry- or hybrid-cooled plants operating in the world today." 346

\subsubsection{ACC Amendment of Project Water Mitigation Requirements}

In November 2010, the ACC agreed with the opponents' concerns and amended Condition No. 4 to read:

Applicant shall utilize all available effluent supplies from the City of Kingman .... and to the degree that Applicant is unable to procure enough effluent for the operation of the entire HVS project, Applicant should utilize dry or hybrid cooling technology in the construction of its facilities as a condition of receiving this CEC. The Applicant cannot operate the plant using groundwater for cooling. If the Applicant determines that not enough effluent will be available for the operation of the plant without using groundwater, it may proceed with construction of the plant using dry or hybrid cooling technology. ${ }^{347}$

In reaching this decision, the ACC determined that the previous language for Condition No. 4 "leaves too much to chance" because the project would rely on groundwater "in an area that is known for its aridity and water scarcity." The ACC further reasoned:

However, even more compelling...is the recent trend by other states and federal agencies toward encouraging and even requiring dry or hybrid cooling technology for thermal plants.... [D]ry cooling is a technology that is currently available to energy developers, and will be used by CSP developers in both Nevada and California, where desert conditions led the project developers and regulators to choose the more environmentally sensitive cooling technology. ${ }^{348}$

With respect to HVS's concerns regarding the cost of dry cooling, the ACC found that the developer had provided no evidence why it would be unable to rely on this technology when 
"most similarly situated CSP plants that either have or are undergoing siting review have chosen to move forward with this technology." The decision marked the first time that the ACC had required dry cooling for a power plant. The ACC also found that the $3 \%-8 \%$ increase in the price premiums associated with dry cooling was "a reasonable tradeoff for Mohave County's groundwater supplies." 349

Then-ACC Chairman Kris Mayes, who sponsored the amendment, also expressed concerns that the project would use Arizona groundwater to export energy to Nevada at a time when CSP plants in Nevada are being required to use dry cooling technology. "Why should Arizona ratepayers, taxpayers, and residents have to sell their water to Nevada," she was quoted as saying in an October 2010 news article describing a hearing on the amendment. ${ }^{350}$

\subsubsection{Current Status}

Following the ACC's amendment, HVS's plans to build the project appear to have stalled. ${ }^{351}$ HVS has not yet contracted with Kingman to supply treated wastewater and questions remain over how HVS would transport water to the site, including the exact cost and length of a pipeline as well as the acquisition of the necessary rights-of-way. ${ }^{352}$ Furthermore, HVS's parent company Mohave Sun Power had reached a funding agreement with ACS Cobra, but the agreement fell apart in April 2011 when Mohave Sun Power was unable to secure a power purchase agreement with Nevada Energy. In turn, this hindered Mohave's ability to secure a loan from DOE. ${ }^{353}$ It is uncertain exactly what role the ACC's dry cooling amendment played in the financing challenges associated with the project, especially given the falling cost of natural gas and PV.

Notably, while the ACC required dry cooling for Hualapai, it did approve the 280-MW Solana Project in Gila Bend, Arizona, which is wet-cooled and was designed to use about 1,600 acrefeet of water per year. However, unlike the Hualapai project, the Solana project received relatively little public opposition, due in part to the fact that it is being built on previously irrigated farmland rather than raw, un-irrigated land. It is also estimated to consume $75 \%-85 \%$ less water than the previous agricultural uses. ${ }^{354}$

The Hualapai project shows how public concerns regarding water use can play a significant role in the siting of CSP project, particularly if the project is wet-cooled and located close to a population or agricultural center on previously un-irrigated land. The project also illustrates the growing trend toward the use of technologies that minimize freshwater use, including dry cooling and the use of effluent (when feasible), and shows that concerns about the impacts of CSP development on water resources can trump economic benefits in some cases.

Of further note, the project demonstrates the important role that utility commissions can play in addressing and mitigating the potential impacts of CSP plants on water resources. This is especially true for cases in Arizona where the proposed plant is sited outside of an AMA and therefore does not require a water right permit. While most state water right approval processes typically focus on the availability of water and injury to other water right holders, the ACC's decision to require dry cooling and the use of effluent for the Hualapai project shows that some utility commissions can have authority to impose additional restrictions on a project's water use that might not be available through traditional water right permitting processes. 


\subsection{California - Genesis Solar Energy Project}

The Genesis Solar Energy Project is a 250-MW parabolic trough CSP plant located in Riverside County, California that became operational in November 2013 and March 2014. Developed by Genesis Solar LLC, a subsidiary of NextEra Energy Resources, the \$1 billion dry-cooled project was built on almost 1,950 acres of BLM-managed public lands 25 miles west of Blythe (population 20,817) in southeastern California and 200 miles east of Los Angeles. Although the project was sited on undisturbed land, the area has been used in the past for grazing and offhighway vehicle recreation. The project was also processed jointly through BLM and CEC's cooperative model and received approval to be constructed on public lands as part of BLM's fast-track approval process. ${ }^{355}$

The project has secured a power purchase agreement with the Pacific Gas and Electric Company and is being backed by an $\$ 825$ million DOE loan guarantee. Initial estimates found that the project would generate 646 direct jobs per month with a payroll of $\$ 165.5$ million during construction and create 40-50 permanent full-time jobs once operational. The project was also expected to create 446 indirect jobs during construction as well as 124 indirect jobs during operation. Estimated fiscal benefits include $\$ 627,000$ per year in property taxes, $\$ 1.3$ million per year in state and local sales tax during construction, and $\$ 44,000$ per year in state and local sales tax during operation. ${ }^{356}$

\subsubsection{Original Proposed Use of Wet Cooling Technology}

The project was originally proposed as a wet-cooled plant that would have required 1,604 acrefeet of groundwater per year, most of which was for cooling. In addition, the project would have required an estimated 2,440 acre-feet during its construction for site preparation and dust suppression. Notably, the on-site groundwater was brackish and poor quality, with high levels of total dissolved solids, and likely impaired for municipal, potable, and agricultural uses. ${ }^{357}$

Although California's policies allow for the use of impaired waters for power plant cooling purposes under certain circumstances, the project's proposed groundwater use nevertheless raised a number of concerns regarding its cumulative impact on water resources in the area, including possible impacts to springs and seeps in the Chuckwalla Valley Groundwater Basin. In February 2010, the CEC issued a decision and scoping order that clarified the SWRCB's and CEC's policies on the use of water for power plant cooling purposes. The order found that those policies require "projects seeking to use groundwater for power plant cooling to use the least amount of the worst available water, considering all applicable technical, legal, economic, and environmental factors (emphasis added). $" 358$

A June 2010 CEC SA raised additional concerns that while the groundwater at issue was possibly the "worst quality water reasonably available for the purposes of the project," the project did not comply with California's policies because it failed to use the "least amount of water available." ${ }^{359}$ The assessment also found that Genesis Solar had not shown that dry cooling was not environmentally undesirable or economically unsound, especially in light of "parallel applications in the same region for dry-cooled solar power plants." ${ }^{360}$ Likewise, BLM issued a Draft Environmental Impact Statement in March 2010 as part of its right-of-way approval process that made similar conclusions. ${ }^{361}$ Consequently, both CEC staff and BLM ultimately 
recommended dry cooling for the project, which they found would reduce the project's water use to 202 acre-feet per year during operations. ${ }^{362}$

\subsubsection{Switch to Dry Cooling and Project Approval}

In July 2010, Genesis Solar revised the project to rely on dry cooling and received approval from CEC and BLM shortly thereafter. In its final order approving the project, CEC found that the project's use of dry cooling is "consistent with the State's water policy" as set forth by the SWRCB and CEC and "will provide environmental benefits through reduced water use in a water-constrained environment, reduced use of treatment chemicals, reduction in solid waste generation, and avoidance of substantial harm to biological resources and wetland/substrate habitat." "363 Likewise, BLM's record of decision granting the project's right-of-way application found that dry cooling was the environmentally preferred alternative, met "national renewable energy goals and objectives," and "will reduce impacts to water resources and allow the fully requested $250 \mathrm{MW}$ of energy development.",364

\subsubsection{Colorado River Issues}

Notwithstanding the Genesis Project's eventual shift to dry cooling, its proposed water use still raised questions about potential compliance issues with the Colorado River Compact. As discussed in Section 5.3.5, groundwater withdrawals in the Lower Colorado River Basin that are replaced with river water require an entitlement under the BCPA and the 2006 Consolidated Decree in Arizona v. California. In June 2010, the Colorado River Board of California, which is responsible for protecting California's rights and interests in the river, raised concerns that BLM lands proposed for the project were located within the "accounting surface area" and that the USGS had determined that the aquifer underlying the area was hydraulically connected to the river. If the project's wells were determined to pump river water, the board opined that the project would need to secure an entitlement "before such a use is deemed to be a legally authorized use of this groundwater." Because no additional river water is available for new projects, the board stated that the project might need to obtain its water through an existing BCPA Section 5 contract holder. ${ }^{365}$

CEC ultimately found that it was unclear if the project would draw Colorado River and determined that there was not enough evidence to impose a condition requiring Genesis Solar to obtain a Colorado River entitlement. However, CEC did find that the project's withdrawal of water from the Chuckwalla Basin could decrease the amount of groundwater underflow to the adjacent Palo Verde Mesa Groundwater basin, which is located next to the river. ${ }^{366}$

Genesis Solar contended that a groundwater mound in the Palo Verde Valley and its relationship to the river made it impossible for pumping in the Chuckwalla Basin to move water from the river. Although CEC staff did not accept this contention, it did agree that there was no existing legal requirement for the project to obtain an entitlement to river water and that Genesis Solar would offset the project's impacts to the Palo Verde Basin. Additionally, CEC noted that the amount of water required to offset depletions in the Palo Verde Basin "will be greater than what would be required to offset any theoretical impact to the river or drains, and thus the measure is conservative." 367 The CEC also required Genesis Solar to implement a water conservation program to offset the projects use of groundwater. ${ }^{368}$ 
BLM also addressed this issue in its right-of-way approval process. In its final Record of Decision approving the project, BLM declined to make a determination as to whether the groundwater the project would withdraw is hydrologically connected to the river due to the "uncertainty" of the Bureau of Reclamation's accounting surface methodology. It also determined that no formal regulation exists that requires Genesis Solar to acquire an allocation, noting that Reclamation "has not finalized its rule on the accounting methodology" for the river. Should reclamation finalize the currently proposed accounting surface method, BLM indicated that it would work with Genesis to ensure that "appropriate processes are followed to obtain such an allocation." 369

However, at least one organization challenged BLM's decision regarding the project's possible impacts on the River. In December 2010, the California Unions for Reliable Energy (CURE) and two individuals sued the Secretary of the Interior and BLM in federal court, claiming that the Chuckwalla Basin is hydrologically connected to the Colorado River. Even though the project had switched to dry cooling and reduced its projected operational water demands to 202 acre-feet per year (notwithstanding the 2,440 acre-feet needed for construction), CURE said any pumping for the project must be viewed as a withdrawal subject to the Law of the River. ${ }^{370}$ CURE argued that the federal government's fast-tracked approval of the project violated NEPA because BLM did not adequately analyze and mitigate the project's impact on the Colorado River while also violating the FLMPA and the Administrative Procedure Act by not acting in accordance with the Law of the River. ${ }^{371}$ Specifically, CURE said BLM "did not take the requisite 'hard look' at the project's significant effects on the Colorado River because BLM did not provide quantitative or detailed qualitative information regarding the...Project's effect on the Colorado River, as required by NEPA." ${ }^{372}$ Thus, CURE asked the court to vacate BLM's right-of-way approval for the project and to enjoin its withdrawal of groundwater from the basin and "any grounddisturbing activities" until the defendants comply "with the substantive and procedural mandates of NEPA and FLMPA." 373

However, the district court ultimately dismissed the suit in September 2011, finding that the plaintiffs lacked standing because they failed to provide evidence showing that they would suffer actual injury. Among other findings, the court was persuaded by information that The Bureau of Reclamation provided in response to requests by the plaintiffs that showed that the project's wells would maintain water levels above those needed to be replaced by the river. ${ }^{374}$

\subsubsection{Impacts to Non-Water Resources}

The construction of the Genesis project has prompted various groups to raise concerns about possible impacts to resources other than water, including environmental and cultural resources that may postpone or possibly derail the project. In particular, in November 2011 earthmovers on the project site turned up Native American artifacts and a possible cremation, which are protected by the federal Native American Graves Protection and Repatriation Act. Native American bones have also been discovered near the project site and work was halted on 400 acres, or one-fifth of the project's total area, for archaeologists to conduct an assessment. ${ }^{375}$

The Colorado River Indian Tribes (CRIT), who have ancestral ties to the site, also asked that construction of the project be halted until further studies are conducted. In addition, the La Cuna de Aztlan Sacred Sites Protection Circle raised the possibility of taking legal action based on the 
project's possible impacts to Native American artifacts as well as its impacts on wildlife, including nearby desert kit foxes, some of which have contracted distemper. ${ }^{376}$

Much of the concern associated with the project's impacts to these resources pertains to BLM's "fast-track" process, which opponents say moved too quickly and did not adequately avoid adverse impacts. As stated in a January 2012 letter from CRIT Chairman Eldred Enas to BLM:

The fast-tracking approach has resulted in short-reviews, poor consultation practice, and needless conflict, causing all concerned undue hardship, and failing to adequately protect invaluable, irreplaceable resources of many varieties. With so many proposals to monitor, and the flood of new project applications overwhelming the staff of BLM Field Offices all over the region, CRIT feels it must be proactive in the protection and oversight of cultural resources in the area.... The Tribe believes that needless disturbance of significant cultural resources has occurred at the Genesis site, and that these unfortunate outcomes are like to occur again and again if the "fast-track" protocols remain in effect. ${ }^{377}$

Ultimately the tribe and NextEra were able to resolve these concerns through a mitigation agreement and construction on the project has continued. ${ }^{378}$ Nevertheless, claims such as those made by CRIT have the potential to delay or possibly derail a project if they are not adequately addressed. $^{379}$

\subsubsection{Project Status}

The Genesis Project demonstrates a number of key points about CSP development in the Southwest. First, it underscores an overall trend in the Southwest, especially in California, that appears to favor dry cooling and other alternative cooling technologies. As dry cooling becomes more common in the region, it will likely become increasingly difficult for CSP developers to claim that dry cooling is economically infeasible. Using impaired waters with wet cooling also does not guarantee a project's approval.

Second, the project shows that BLM's "fast-track" approval process remains controversial to some extent, which means that CSP projects approved through this process may become subject to lawsuits or other challenges regarding their impacts to water and other resources, even after they have secured the necessary right-of-way approval from BLM.

Third, as with the Hualapai project, the Genesis project illustrates the important role that nonwater management agencies, such as CEC, can play in restricting or conditioning the water use of proposed CSP projects.

Lastly, the project shows that even dry-cooled plants can raise concerns about cumulative impacts on a groundwater basin in delicate balance and compliance issues with the laws governing the Colorado River.

\subsection{Nevada - Nevada Solar One}

Acciona Energy's Nevada Solar One plant is an example of a CSP project in the Southwest that has encountered comparatively few obstacles, including issues involving water. Opened for 
commercial operation in 2007, the plant is sited on 400 acres of desert land leased from Boulder City, Nevada, and uses parabolic troughs to produce about 50-64 MW of energy per year at a cost reported to range from $\$ 0.15-\$ 0.17 / \mathrm{kWh}$. All of the project's power is sold to Nevada Energy through a long-term power purchase agreement. ${ }^{380}$

The project cost about $\$ 266$ million to build over the course of 16 months with a workforce that averaged 400 and peaked at 850 . There are 28 permanent jobs. At the time of its construction, the project was the largest solar thermal energy project to be built since $1991 .^{381}$

\subsubsection{Project Water Use}

Nevada Solar One is wet-cooled and has historically used about 400 acre-feet of water per year. Unlike other CSP plants, it uses potable water under a water service agreement with Boulder City. The city's water supply consists of Colorado River water withdrawn from Lake Mead. ${ }^{382}$

The city and the project executed their first water service agreement in 2003, which required the city to provide the project with: (1) a continuous flow rate of $325 \mathrm{gpm}$; (2) minimum pressure of 25 pounds per square inch; (3) water quality equal to the quality of potable water supplied to residents; and (4) up to 300 acre-feet per year. Like other water users, the project's water rates are determined in accordance with the applicable portions of the city code. ${ }^{383}$

The parties have since amended and restated the agreement several times to account for a proposed expansion of the project. In 2007, the parties agreed to increase the amount of water project to the plant to $450 \mathrm{gpm}$ and 415 acre-feet per year. Although the city had sufficient amounts of water to cover the increase, most of the capacity in its potable water line had been allocated to another power project, and the city did not want to obligate itself to provide amounts of water that were above the capacity of its existing line. To overcome the city's concerns, Nevada Solar One agreed to construct a raw water line to a nearby quarry that relies on potable water. With the installation of the new line, the quarry could rely on raw water supplies, thereby freeing up potable water for use by Nevada Solar One. ${ }^{384}$

Although the deadline to construct the raw water line to the quarry has since passed, the city has not demanded that Nevada Solar One construct the pipeline because the parties had been working cooperatively to explore the possibility of providing reclaimed wastewater to the project. Nevertheless, Nevada Solar One eventually opted not to enter into a contract to use wastewater, asking instead for an extension and permission to transfer the responsibility to build the pipeline to its parent company, Acciona. ${ }^{385}$

In July 2012, the city approved a contract that transferred Nevada Solar One's obligation to build the pipeline to Acciona. Under the contract, Acciona agreed to complete the pipeline by December 31,2012 , or pay the city $\$ 2$ million to design and construct the pipeline to the quarry itself. The parties further agreed that if Acciona exercised an option to expand the project and needed to utilize raw water from the quarry pipeline, the company would construct another water supply line that would connect the quarry pipeline to the option property or pay the city an additional $\$ 2$ million to construct the pipeline. ${ }^{386}$

In conjunction with the Acciona agreement, the city also approved a separate water service agreement with Nevada Solar One that increased the city's water service commitment from 450 
gpm to $500 \mathrm{gpm}$. This agreement also gave the city the option of providing Nevada Solar One with a one-year advance notice to reduce its potable water consumption from 415 acre-feet per year to 50 acre-feet per year. In lieu of the reduced potable water supplies, the city would provide 425 acre-feet of raw water instead. ${ }^{387}$

\subsubsection{Siting Considerations}

Nevada Solar One's location on city-owned land about 15 miles from downtown Boulder City is a relatively unique feature that distinguishes the project from other CSP plants, which are often located far from population centers. This is due in part to the fact that the city encompasses over 200 square miles and is the largest incorporated community in Nevada but has a relatively small population of around 16,000. In comparison, Las Vegas comprises 136 square miles and is home to 584,000 people. $^{388}$

The project is also located within an "energy zone" the city has created to attract renewable energy development. The city began planning to attract solar energy development in the mid$1990 \mathrm{~s}$ and originally amended its charter to set aside 3.5 square miles (2,200 acres) for solar development. It has since set aside over 12.5 square miles (8,000 acres) as an "energy zone." The city leases portions of this land to various energy projects such as Nevada Solar One and the 58MW Copper Mountain One PV plant. Additional solar projects are also planned. ${ }^{389}$

Because the city owns the land on which Nevada Solar One and the other projects will be built, project developers are able to avoid the lengthy process and expense of building on federal land. Although the city does its due diligence to avoid environmental impacts, it does not require the types of environmental studies required by NEPA, which appeals to some developers. ${ }^{390}$

The location of the plant within the city limits also makes it financially feasible for the plant to connect to the city's water supply. By receiving water through the city, Nevada Solar One was able to avoid many of the water rights conflicts and groundwater pumping concerns associated with other CSP projects. Namely, by relying on city water, the project did not need to acquire its own water rights, thereby avoiding the time, expense, and opposition often associated with applications to appropriate water or acquire existing water rights.

Nevertheless, the project ultimately relies on water from the Colorado River, which is under increasing strain due to drought and increased demands in the Southwest. If the city's water supply is strained or curtailed for these or other reasons, such limitations could theoretically hinder its ability to provide water to the project or possibly lead to objections about the project's use of potable or raw water supplies.

However, the city reports that it has "plenty of water allocation remaining" to serve the project throughout its design life. This is due in part to the fact that the city operates with minimal to no growth and has a "very strong desire" to stay small. Moreover, the city has set limits on potable uses in its latest requests for proposals from solar companies. ${ }^{391}$

It is also important to note that unlike other CSP plants, which are often proposed for remote areas of the desert, Nevada Solar One was built in an area in which three transmission lines were already in place in close proximity to an existing gas power plant. A substation that transmits energy to Los Angeles is also located in the city. This reduced costs and eliminated many of the 
concerns that other, more remote CSP projects experienced with securing connections to transmission lines. ${ }^{392}$

\subsubsection{Economic Impacts to Boulder City}

Acciona's lease payments for the use of city land for the Nevada Solar One project provide about $\$ 700,000$ per year to the city's general fund. These payments will rise over the 40 -year term of the lease in accordance with the Consumer Price Index. In 2007, the lease payments totaled about $2.3 \%$ of the city's total budget at the time. The project's property tax payments, which are paid to Clark County, also total around $\$ 400,000$ per year. ${ }^{393}$

The lease payments from Nevada Solar One and other existing and proposed energy projects on city land have the potential to generate a significant amount of income for the city. According to some projections, the city will collect about $\$ 12$ million per year in lease payments once planned projects are brought online, or over $\$ 480$ million over the life of the projects' contracts, which range from 20-50 years. In 2011, the city's budget was roughly \$25 million, which means that the leases could increase its revenue by $50 \% .{ }^{394}$ Additionally, two of the proposed projects have made upfront payments of $\$ 3.5$ and $\$ 5$ million. ${ }^{395}$

In his 2012 state of the city address, Boulder City Mayor Roger Tobler said payments from the Nevada Solar One project and other projects in the Energy Zone would be an "invaluable asset" that would enable the city to: (1) eliminate its debt; (2) restore capital reserves and other city funds; (3) rebuild the ending balance of its general fund; (4) stabilize the city's revenue stream "for years to come;" and (5) cover rising infrastructure and maintenance costs without raising rates to residents. Tobler further noted:

These developments are also perfect partners for our small town in that they utilize green technologies and have little demand on City resources, so they only impact the quality of life in our community in a positive way. Boulder City is very pleased to work with Nevada Solar One and Copper Mountain Solar One. Both of these companies have been excellent community partners in every way. ${ }^{396}$

Notwithstanding these impacts to the city's finances, some reports indicate that the project's construction and operation have had relatively little impact on the city's economy. This is due in part to concerns that many of the workers for the project came from the larger Las Vegas metropolitan area or elsewhere rather than the city itself, which is comprised of an older, educated populace that may not have had the skills or desire to work on the plant's construction. Furthermore, the small number of permanent jobs and the possibility that workers may have lived elsewhere in the region in light of the city's relatively high rents likely resulted in minimal economic impacts associated with the plant's operation. ${ }^{397}$

\subsubsection{Public Opinion}

The Nevada Solar One project received relatively little, if any, public opposition. When the city released its request for proposals to build a solar project in 2003, which ultimately led to the construction of Nevada Solar One, the possibility of the city receiving lease payments from such a project led many residents to view the possible construction of a CSP plant favorably. Furthermore, a 2010 study of the project's socio-economic impacts found that an 
"overwhelming" number of citizens believed the project had either positive effects or no effect on the city. Once again, the project's generation of lease revenue for the city was cited as a "positive long-term impact." 398

\subsubsection{Project Status}

Since becoming operational in 2007, Nevada Solar One has operated without much, if any, controversy. This shows that it is possible for CSP plants to avoid the types of controversies discussed in the other case studies. However, this lack of controversy is due in large part to circumstances that will likely be unavailable for most CSP projects in the Southwest, namely access to city-owned land near existing transmission lines and the ability to acquire water through a municipal water system. Even in those cases where a project is located near a city, it is possible that the city may not have sufficient potable or raw water supplies to provide for cooling purposes. Nevada Solar One is also significantly smaller than many of the newer CSP plants that have been proposed in the Southwest and therefore requires less water.

Nevertheless, the project does show that CSP projects, including those that are wet-cooled, can minimize opposition to their water use and possible impacts to environmental and cultural resources by selecting well-suited locations. It further shows that if sufficient and suitable cityowned land is available, the lease payments generated by a CSP plant can provide significant benefits to a city's finances that can garner support among its officials and citizens. 


\section{Conclusion and Observations}

CSP development in the Southwest has the potential to provide a renewable source of energy that could help move the nation toward lower carbon emissions.

While the number of CSP plants has increased in recent years and additional plants have been proposed, CSP still faces challenges that could hinder its growth. Challenges not directly related to water issues include securing access to transmission lines and CSP's relatively high capital costs compared to other energy sources may lessen its appeal to developers and utilities, especially when compared to natural gas and PV, which have seen significant price declines in recent years.

While CSP is a relatively new technology and its costs will likely become more competitive over time as more plants come online, there is some uncertainty as to whether CSP will be able to keep pace with other technologies, especially given recent decisions by some developers to convert proposed CSP plants to PV.

The ability of CSP projects to access water for cooling and other purposes adds to the uncertainty surrounding the future of CSP deployment in the Southwest. Specifically, the overall trend in the region is moving toward dry cooling as the preferred option for state and federal regulators. On one hand, dry cooling appears to pose relatively minor impacts to scarce water resources and appears to alleviate many of the concerns raised by wet-cooled plants, which could help projects secure faster approval and avoid costly delays and public opposition. However, depending on a plant's location, dry cooling may be less efficient and therefore more costly than wet cooling. Even if these costs are relatively small, they still have the potential to lessen CSP's competitiveness with cheaper forms of energy, primarily PV, which also uses relatively little water.

There are a number of factors that could make CSP more competitive over the long-term. Specifically, CSP's costs are dependent on the capital costs of its facilities rather than on fuel costs, which could make it more competitive if the prices of natural gas or other fossil fuels increase or fluctuate widely due to increased demand and other factors. Furthermore, increased water prices due to competing demands could raise the cost of wet-cooled fossil fuel plants, thereby making dry-cooled CSP plants more competitive. At the same time, CSP's ability to store energy and provide grid services could allow it to complement and enable the further use of more variable renewable energy sources, such as PV and wind, which could increase the need and demand for CSP.

Because many of the most suitable CSP sites are located on federal land, efforts by BLM and the federal government to streamline the right-of-way approval process may lead to increased CSP deployment. However, as shown in the case studies, such efforts can be more effective by providing adequate review of potential impacts on water resources and other environmental and cultural resources to lessen the potential for lawsuits and other objections that may stall or derail projects after they have secured right-of-way approval. BLM's final PEIS approved in October 2012 attempts to address environmental and cultural resources in the streamlined approval process, but it has not been in effect for long enough to accurately assess the effectiveness of its methods and strategies. 
In light of the above, there are a number of observations regarding the use of water for CSP development that policymakers and project developers may want to consider when evaluating the feasibility and siting of a possible CSP project. These include:

- Location: Where a project is located can have a significant impact on its feasibility and ability to secure federal and state approval. In general, it appears that plants located on undisturbed desert land can generate significant public opposition over concerns regarding impacts to environmental, cultural, and water resources. This appears to be particularly true for wet-cooled plants, although dry-cooled plants may face opposition as well. How much water a CSP project requires will also depend in part upon the location of a project, with projects located in warmer areas generally requiring more water than projects in cooler areas.

- $\quad$ Public vs. Private Land: It appears that CSP projects located on previously irrigated private land (or city-owned land as with Nevada Solar One) face relatively less opposition to their water use than plants sited on federal land. Some developers may also view the process used to approve CSP plants on federal land as overly burdensome and time consuming, which may make private land more appealing to them. However, as is the case in California, many of the most suitable sites for CSP development may be located on federal land and private land may simply be unavailable in some situations.

- Dry and Hybrid Cooling: Regulatory decisions in the Southwest appear to favor a trend toward dry cooling, which is reflected in cooling technology choices of projects that are under development. Projects that rely on this technology could potentially generate less opposition and secure faster approval, at least with respect to water. As more dry-cooled CSP plants are proposed in the Southwest, developers could have a harder time showing that dry-cooled projects are economically infeasible or disadvantaged compared to other CSP projects. However, even if the extra costs associated with dry and hybrid cooling are relatively small, questions remain as to how these costs impact CSP's competiveness with other, cheaper sources of energy, such as PV.

- Wet Cooling: Although wet-cooled plants face more regulatory obstacles and tend to have greater public opposition than their dry-cooled counterparts, there do appear to be some situations in which wet cooling is feasible. Specifically, projects located on private, previously irrigated land that use less water than the previous agricultural uses appear more likely to secure regulatory approval and generate less opposition. The Nevada Solar One project also shows that wet-cooled plants near population centers may be feasible if they can use municipal water supplies or city-owned land, provided that such resources are available and the infrastructure needed to supply water to a plant is not too costly.

- Water Mitigation: Both dry-cooled and wet-cooled CSP plants could face increasing pressure to minimize and mitigate their water use, even if they intend to rely on impaired or other non-potable water resources, as use of these sources may impact other water supplies.

- Indirect Export of Water: Wet-cooled projects that export energy to other states could face increasing opposition over concerns that such projects are essentially exporting a state's water resources. This concern appears to be heightened in situations where the 
energy and water is exported to another state that would likely prohibit the use of wet cooling for new CSP plants.

- Economic Impacts: CSP has the potential to provide significant economic benefits to local communities, counties, and states. These economic benefits must be evaluated in the context of the other impacts of CSP development.

- $\quad$ State and Federal Policies: State and federal policies have the potential to encourage CSP development, as shown by the number of CSP projects proposed in response to state RPSs and DOE's loan guarantee program.

- Colorado River: CSP plants located near the Colorado River have the potential to raise concerns that the groundwater they withdraw could be replaced by river water, which would require an entitlement under the Law of the River. Acquiring an entitlement or proving that an entitlement is not necessary can add to the costs and time needed to approve and construct a project.

- Utility and Energy Commissions: In many cases, state agencies, such as the ACC or CEC, will likely play a critical role in evaluating and approving a proposed CSP project's water use. This is particularly true for projects that rely on groundwater in California or on groundwater located outside of an AMA in Arizona, where permits from state water management agencies are not required to withdraw groundwater.

- Transmission Planning: The lack of available transmission capacity in the Southwest could play a limiting factor on CSP development in the region. Moreover, given the relatively high cost of CSP compared to other energy sources, it may be difficult to justify the costs of building transmission lines to a single CSP plant located in a remote location when other types of power plants can be built closer to existing transmission lines. Consequently, CSP plants may need to be built near existing transmission lines (where possible) or near other CSP projects to be feasible. 


\section{Appendix: Status of Utility-Scale CSP Projects in the United States}

The following tables provide information regarding ground-mounted CSP and PV solar plants that are $1 \mathrm{MW}$ and larger and are operating, under construction, under development, or otherwise proposed.

The tables are based primarily on information from the Solar Energy Industries Association (SEIA) and NREL, with additional input provided from the Southwestern states. ${ }^{399}$ The tables rely on information from SEIA and NREL, most of which is current as of August15, 2014. Please note that not every project identified as "under development" will be completed and some of these projects may have stalled in their development.

Tables A-3, A-4, and A-5 summarize specific CSP projects that are operational, under construction, and under development or otherwise proposed in the United States. Where possible, these tables include information on the types of cooling technologies proposed for these projects, as well as their expected completion or start dates. 
Table A-1. Overview of Utility-Scale CSP and PV Project Capacity in the United States ${ }^{400}$

\begin{tabular}{|l|l|l|l|l|}
\hline Technology & Operating & Under Construction & $\begin{array}{l}\text { Under Development/ } \\
\text { Proposed }\end{array}$ & Total Solar Pipeline \\
\hline CSP & 24 Projects & 4 Projects & $\begin{array}{l}11 \text { Projects } \\
3,240 ~ M W\end{array}$ & 39 Projects \\
& $1,495 \mathrm{MW}$ & $366 \mathrm{MW}$ & 256 Projects & $5,101 \mathrm{MW}$ \\
\hline PV & 403 Projects & 68 Projects & $21,412 \mathrm{MW}$ & 727 Projects \\
& $6,519 \mathrm{MW}$ & $2,451 \mathrm{MW}$ & $\mathbf{2 6 7}$ Projects & $30.382 \mathrm{MW}$ \\
\hline Total & $\mathbf{4 2 7}$ Projects & $\mathbf{7 2}$ Projects & $\mathbf{2 4 , 6 5 2} \mathbf{M W}$ & $\mathbf{7 6 6}$ Projects \\
& $\mathbf{8 , 0 1 4} \mathbf{M W}$ & $\mathbf{2 , 8 1 7} \mathbf{M W}$ & $\mathbf{3 5 , 4 8 3} \mathbf{M W}$ \\
\hline
\end{tabular}

Table A-2. Percentage of MW Capacity in the United States for CSP and PV ${ }^{401}$

\begin{tabular}{|l|l|l|l|}
\hline Operating Projects & Projects Under Construction & Projects under Development & Total Pipeline \\
\hline CSP $-19 \%(M W)$ & $13 \%(M W)$ & $13 \%(M W)$ & $\mathbf{1 4 \%}(\mathbf{M W )}$ \\
\hline PV $-81 \%(M W)$ & $87 \%(M W)$ & $87 \%(M W)$ & $\mathbf{8 6 \%}(\mathbf{M W})$ \\
\hline
\end{tabular}

Table A-3. Operational CSP Plants ${ }^{402}$

\begin{tabular}{|c|c|c|c|c|c|c|c|c|}
\hline State & Developer & Project & $\begin{array}{l}\text { Electricity } \\
\text { Purchaser }\end{array}$ & City/County & Technology/Cooling & $\begin{array}{l}\text { Land } \\
\text { Type }\end{array}$ & $\begin{array}{l}\text { Online } \\
\text { Date }\end{array}$ & Capacity \\
\hline$A Z$ & Abengoa & $\begin{array}{l}\text { Solana Generating } \\
\text { Station }\end{array}$ & $\begin{array}{l}\text { AZ Public } \\
\text { Service }\end{array}$ & Gila Bend & Trough/Wet-cooled & Private & 2013 & 280 \\
\hline$A Z$ & Solargenix & $\begin{array}{l}\text { Saguaro Solar Power } \\
\text { Plant }\end{array}$ & $\begin{array}{l}\text { AZ Public } \\
\text { Service }\end{array}$ & Red Rock & Trough/Wet-cooled & Private & 2005 & 1 \\
\hline CA & Ausra & $\begin{array}{l}\text { Kimberlina Solar } \\
\text { Thermal Plant }\end{array}$ & $\begin{array}{l}\text { CA's Wholesale } \\
\text { Market }\end{array}$ & Bakersfield & Linear Fresnel & Private & 2009 & 5 \\
\hline CA & $\begin{array}{l}\text { BrightSource } \\
\text { Energy }\end{array}$ & $\begin{array}{l}\text { Ivanpah Solar Electric } \\
\text { Generating System I }\end{array}$ & $\begin{array}{l}\text { Pacific Gas \& } \\
\text { Electric }\end{array}$ & Barstow & Tower/Dry-cooled & Public & 2014 & 126 \\
\hline CA & $\begin{array}{l}\text { BrightSource } \\
\text { Energy }\end{array}$ & $\begin{array}{l}\text { Ivanpah Solar Electric } \\
\text { Generating System II }\end{array}$ & So. CA Edison & Barstow & Tower/Dry-cooled & Public & 2014 & 133 \\
\hline
\end{tabular}




\begin{tabular}{|c|c|c|c|c|c|c|c|c|}
\hline State & Developer & Project & $\begin{array}{l}\text { Electricity } \\
\text { Purchaser }\end{array}$ & City/County & Technology/Cooling & $\begin{array}{l}\text { Land } \\
\text { Type }\end{array}$ & $\begin{array}{l}\text { Online } \\
\text { Date }\end{array}$ & Capacity \\
\hline CA & $\begin{array}{l}\text { BrightSource } \\
\text { Energy }\end{array}$ & $\begin{array}{l}\text { Ivanpah Solar Electric } \\
\text { Generating System III }\end{array}$ & $\begin{array}{l}\text { Pacific Gas \& } \\
\text { Electric }\end{array}$ & Barstow & Tower/Dry-cooled & Public & 2014 & 133 \\
\hline CA & eSolar & Sierra Sun Tower & So. CA Edison & $\begin{array}{l}\text { Antelope } \\
\text { Valley }\end{array}$ & Tower/Wet-cooled & Private & 2009 & 5 \\
\hline $\mathrm{CA}$ & Luz & $\begin{array}{l}\text { Solar Energy } \\
\text { Generating Systems } \\
\text { (SEGS) IX }\end{array}$ & So. CA Edison & $\begin{array}{l}\text { Kramer } \\
\text { Junction }\end{array}$ & Trough/Wet-cooled & Private & 1991 & 80 \\
\hline CA & Luz & SEGS VIII & So. CA Edison & $\begin{array}{l}\text { Kramer } \\
\text { Junction }\end{array}$ & Trough/Wet-cooled & Private & 1990 & 80 \\
\hline CA & Luz & SEGS VI & So. CA Edison & $\begin{array}{l}\text { Kramer } \\
\text { Junction }\end{array}$ & Trough/Wet-cooled & Private & 1989 & 30 \\
\hline CA & Luz & SEGS VII & So. CA Edison & $\begin{array}{l}\text { Kramer } \\
\text { Junction }\end{array}$ & Trough/Wet-cooled & Private & 1989 & 30 \\
\hline $\mathrm{CA}$ & Luz & SEGS V & So. CA Edison & $\begin{array}{l}\text { Kramer } \\
\text { Junction }\end{array}$ & Trough/Wet-cooled & Private & 1988 & 30 \\
\hline CA & Luz & SEGS III & So. CA Edison & $\begin{array}{l}\text { Kramer } \\
\text { Junction }\end{array}$ & Trough/Wet-cooled & Private & 1987 & 30 \\
\hline CA & Luz & SEGS IV & So. CA Edison & $\begin{array}{l}\text { Kramer } \\
\text { Junction }\end{array}$ & Trough/Wet-cooled & Private & 1987 & 30 \\
\hline CA & Luz & SEGS II & So. CA Edison & Daggett & Trough/Wet-cooled & Private & 1986 & 30 \\
\hline CA & Luz & SEGS I & So. CA Edison & Daggett & Trough/Wet-cooled & Private & 1985 & 14 \\
\hline $\mathrm{CA}$ & $\begin{array}{l}\text { MMR Power } \\
\text { Solutions }\end{array}$ & Mt. Signal Solar & SDG\&E & $\begin{array}{l}\text { Imperial } \\
\text { Valley }\end{array}$ & Trough & & 2014 & 49 \\
\hline CA & $\begin{array}{l}\text { NextEra Energy } \\
\text { Resources }\end{array}$ & $\begin{array}{l}\text { Genesis Solar Energy } \\
\text { Project }\end{array}$ & $\begin{array}{l}\text { Pacific Gas \& } \\
\text { Electric }\end{array}$ & $\begin{array}{l}\text { Riverside } \\
\text { County }\end{array}$ & Trough/Dry-cooled & Public & 2014 & 250 \\
\hline CA & $\begin{array}{l}\text { Soitec Solar } \\
\text { Development }\end{array}$ & Newberry Solar 1 & & $\begin{array}{l}\text { San } \\
\text { Bernardino } \\
\text { County }\end{array}$ & Trough/Wet-cooled & & 2013 & 2 \\
\hline $\mathrm{FL}$ & Florida Power & Martin Next Generation & FL Power \& & Martin & Trough/Wet-cooled & Private & 2010 & 75 \\
\hline
\end{tabular}




\begin{tabular}{|c|c|c|c|c|c|c|c|c|}
\hline State & Developer & Project & $\begin{array}{l}\text { Electricity } \\
\text { Purchaser }\end{array}$ & City/County & Technology/Cooling & $\begin{array}{l}\text { Land } \\
\text { Type }\end{array}$ & $\begin{array}{l}\text { Online } \\
\text { Date }\end{array}$ & Capacity \\
\hline & \& Light Co. & Solar Energy Center & Light Co. & County & & & & \\
\hline $\mathrm{HI}$ & Sopogy & $\begin{array}{l}\text { Holaniku at Keahole } \\
\text { Point }\end{array}$ & HEILCO & Kona & Trough/Wet-cooled & Private & 2009 & 2 \\
\hline $\mathrm{HI}$ & Sopogy & Kalaeloa Solar One & & Oahu & & & 2013 & 5 \\
\hline NV & Acciona & Nevada Solar One & NV Energy & Boulder City & Trough/Wet-cooled & Private & 2007 & 64 \\
\hline NV & Acciona & $\begin{array}{l}\text { Nevada Solar One } \\
\text { Expansion }\end{array}$ & NV Energy & Boulder City & Trough/Wet-cooled & Private & 2009 & 11 \\
\hline & & & & & & & Total & $\begin{array}{l}24 \text { Plants } \\
1,495 \mathrm{MW}\end{array}$ \\
\hline
\end{tabular}

Table A-4. CSP Projects Under Construction ${ }^{403}$

\begin{tabular}{|c|c|c|c|c|c|c|c|c|}
\hline State & Developer & Project & $\begin{array}{l}\text { Electricity } \\
\text { Purchaser }\end{array}$ & City/County & $\begin{array}{l}\text { Technology } l \\
\text { Cooling }\end{array}$ & $\begin{array}{l}\text { Land } \\
\text { Type }\end{array}$ & $\begin{array}{l}\text { Start } \\
\text { Year }\end{array}$ & Capacity \\
\hline$A Z$ & Arreva & $\begin{array}{l}\text { TEP's Sundt Boost } \\
\text { Project }\end{array}$ & $\begin{array}{l}\text { Tuscon Electric } \\
\text { Power }\end{array}$ & Tuscon & $\begin{array}{l}\text { Fresnel/Wet- } \\
\text { cooled }\end{array}$ & Private & Unknown & 5 \\
\hline CA & Abengoa & Mojave Solar & $\begin{array}{l}\text { Pacific Gas \& } \\
\text { Electric }\end{array}$ & $\begin{array}{l}\text { San } \\
\text { Bernadino }\end{array}$ & $\begin{array}{l}\text { Trough/Wet- } \\
\text { cooled }\end{array}$ & Private & 2014 & 250 \\
\hline NV & SolarReserve & $\begin{array}{l}\text { Crescent Dunes Solar } \\
\text { Energy Project }\end{array}$ & NV Energy & Nye County & Tower/Hybrid & Public & Unknown & 110 \\
\hline UT & $\begin{array}{l}\text { Infinia } \\
\text { Corporation }\end{array}$ & Tooele Army Base & & Tooele & $\begin{array}{l}\text { Dish/Engine/ } \\
\text { Wet-cooled }\end{array}$ & Public & Unknown & 1.5 \\
\hline & & & & & & & Totals & $\begin{array}{l}4 \text { Plants } \\
366.5 \\
\text { MW }\end{array}$ \\
\hline
\end{tabular}


Table A-5. CSP Projects Under Development ${ }^{404}$

\begin{tabular}{|c|c|c|c|c|c|c|c|}
\hline State & Developer & Project & $\begin{array}{l}\text { Electricity } \\
\text { Purchaser }\end{array}$ & City/County & $\begin{array}{l}\text { Technologyl } \\
\text { Cooling }\end{array}$ & Land Type & Capacity \\
\hline$A Z$ & Albiasa & Kingman Project & Unknown & Kingman & $\begin{array}{l}\text { Trough/Wet- } \\
\text { cooled }\end{array}$ & Private & 200 \\
\hline$A Z$ & SolarReserve & $\begin{array}{l}\text { Crossroads Solar } \\
\text { Energy Project }\end{array}$ & Unknown & Gila Bend & $\begin{array}{l}\text { Tower/Wet- } \\
\text { cooled }\end{array}$ & Private & 150 \\
\hline$A Z$ & SolarReserve & $\begin{array}{l}\text { Quarzsite Solar Energy } \\
\text { Project }\end{array}$ & Unknown & La Paz County & $\begin{array}{l}\text { Tower/Dry- } \\
\text { cooled }\end{array}$ & Public & 100 \\
\hline CA & $\begin{array}{l}\text { BrightSource } \\
\text { Energy }\end{array}$ & Sonoran West & So. CA Edison & Riverside & $\begin{array}{l}\text { Tower/Dry- } \\
\text { cooled }\end{array}$ & Private & 540 \\
\hline CA & $\begin{array}{l}\text { BrightSource } \\
\text { Energy/Abengoa }\end{array}$ & $\begin{array}{l}\text { Palen Solar Power } \\
\text { Project }\end{array}$ & So. CA Edison & Desert Center & $\begin{array}{l}\text { Tower/Dry- } \\
\text { cooled }\end{array}$ & Public & 500 \\
\hline CA & NextEra Energy & Beacon & Unknown & California City & $\begin{array}{l}\text { Trough/Wet- } \\
\text { cooled } \\
\text { (Reclaimed } \\
\text { Water) }\end{array}$ & Private & 250 \\
\hline CA & SolarReserve & $\begin{array}{l}\text { Rice Solar Energy } \\
\text { Project }\end{array}$ & $\begin{array}{l}\text { Pacific Gas \& } \\
\text { Electric }\end{array}$ & Riverside County & $\begin{array}{l}\text { Tower/Dry- } \\
\text { cooled }\end{array}$ & Private & 150 \\
\hline $\mathrm{CO}$ & SolarReserve & $\begin{array}{l}\text { Saguache Solar Energy } \\
\text { Project }\end{array}$ & Unknown & Saguache County & $\begin{array}{l}\text { Tower/Dry- } \\
\text { cooled }\end{array}$ & Private & 200 \\
\hline NV & $\begin{array}{l}\text { BrightSource } \\
\text { Energy }\end{array}$ & Coyote Springs 1 & $\begin{array}{l}\text { Pacific Gas \& } \\
\text { Electric }\end{array}$ & Coyote Springs & $\begin{array}{l}\text { Tower/Dry- } \\
\text { cooled }\end{array}$ & Private & 200 \\
\hline NV & $\begin{array}{l}\text { BrightSource } \\
\text { Energy }\end{array}$ & Coyote Springs 2 & $\begin{array}{l}\text { Pacific Gas \& } \\
\text { Electric }\end{array}$ & Coyote Springs & $\begin{array}{l}\text { Tower/Dry- } \\
\text { cooled }\end{array}$ & Private & 200 \\
\hline NV & $\begin{array}{l}\text { BrightSource } \\
\text { Energy }\end{array}$ & Apex-BSE & Unknown & Clark County & Tower & Public & 750 \\
\hline & & & & & & & $\begin{array}{l}11 \text { Plants } \\
3,240 \mathrm{MW}\end{array}$ \\
\hline
\end{tabular}




\section{References}

${ }^{1}$ W. Governors' Ass'n, Policy Resolution 10-14, 1 (2010).

${ }^{2}$ W. Governors' Ass'n, 10-Year Energy Vision, 11 (2013).

${ }^{3}$ W. Governors' Ass'n, Policy Resolution 2014-03, 4 (2013).

${ }^{4}$ W. Governors' Ass'n, Regional Transmission Expansion Planning, http://www.westgov.org/initiatives/rtep.

${ }^{5}$ Nat'l Renewable Energy Lab., Fact Sheet: Solar Power and the Electric Grid, NREL/FS-6A2-45653 (2010).

${ }^{6} I d$.

${ }^{7}$ Nat'1 Renewable Energy Lab., Concentrating Solar Resources of the United States (2010).

${ }^{8}$ U.S. DEP'T OF ENERGY, SUNSHOT VISION STUDY, REPORT NO.: DOE/GO-102012-3037 (Feb. 2012)

[hereinafter SUNSHOT VISION STUDY], http://www.nrel.gov/docs/fy12osti/47927.pdf.

${ }^{9}$ Mark Mehos, Dan Kabel \& Phil Smithers, Planting the Seed: Greening the Grid with Concentrating Solar Power, IEEE POWER \& ENERGY MAGAZINE, May/June 2009 at 55.

${ }^{10}$ JORDAN MACKNICK, ROBIN NEWMARK, GARVIN HEATH \& KATHLEEN HALLETT, NAT'L RENEWABLE ENERGY LAB., A REVIEW OF OPERATIONAL WATER CONSUMPTION AND WITHDRAWAL FACTORS FOR ELECTRICITY GENERATING TECHNOLOGIES (2011).

${ }^{11}$ Craig Turchi; Mike WAgner, \& Charles Kutscher, NAT'L Renewable ENERGy Lab., Water USE IN PARABOLIC TROUGH POWER Plants: SUMMARY RESUlTS FROM WORLEYPARSONS' ANALYSES (Dec. 2010), http://www.nrel.gov/docs/fy11osti/49468.pdf.

${ }^{12} \mathrm{Id}$.

${ }^{13} \mathrm{Id}$.

${ }^{14}$ Macknick, J., Newmark, R., Heath, G., and Hallett, KC. 2012. Operational water consumption and withdrawal factors for electricity generating technologies: a review of existing literature. Environmental Research Letters. 7 (045802).

${ }^{15}$ Macknick, J., Lee, C., Mosey, G., and Melius, J. (2013). Solar Development on Contaminated and Disturbed Lands. NREL Report No. TP-6A20-58485.

${ }^{16}$ SUNSHOT VISION STUDY, supra note 11.

${ }^{17}$ SOLAR ENERGY IND. ASS'N, UTILITY-SCALE SOLAR ProJeCts IN THE United STATES OPERATING, UNDER CONSTRUCTION, OR UNDER DEVELOPMENT (Aug. 15, 2012), http://www.seia.org/researchresources/major-solar-projects-list.

${ }^{18}$ U.S. ENERGY INFO. ADMIN., FORM EIA-860, ANNUAL ELECTRIC GENERATOR REPORT. ${ }^{19} \mathrm{Id}$.

${ }^{20}$ Robert Glennon and Andrew Reeves, Solar Energy's Cloudy Future, 1 ARIZ. J. OF ENVTL. L. \& POL'Y 92, $106(2010)$.

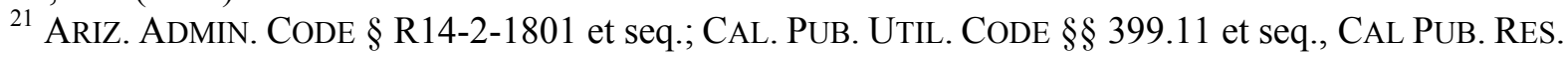
CODE $\S 25740$ et seq.; NEV. REV. STAT. § 704.7801 et seq.; NEV. AdMIN. CODE $§ 704.8831$ et seq.; LCB File R167-05 (Revised Nevada Regulations by the Public Utilities Comm'n of Nev.), http://www.leg.state.nv.us/register/2005Register/R167-05RA.pdf; A.B. 150, $76^{\text {th }}$ Reg. Sess. (Nev. 2011), http://www.leg.state.nv.us/Session/76th2011/Bills/AB/AB150 EN.pdf (setting forth the authorities for the RPSs of Arizona, California, and Nevada). See also DATABASE OF STATE INCENTIVES FOR RENEWABLES AND EFFICIENCY, ARIZONA: INCENTIVES/POLICIES FOR RENEWABLES \& EFFICIENCY, RENEWABLES PORTFOLIO STANDARD (Sept. 2012), http://www.dsireusa.org/incentives/incentive.cfm?Incentive Code $=\mathrm{AZ} 03 \mathrm{R} \& \mathrm{re}=0 \& \mathrm{ee}=0$; DATABASE OF STATE INCENTIVES FOR RENEWABLES AND EFFICIENCY, CALIFORNIA: INCENTIVES/POLICIES FOR 
RENEWABLES \& EFFICIENCY, RENEWABLES PORTFOLIO STANDARD (April 2012),

http://www.dsireusa.org/incentives/incentive.cfm?Incentive Code $=$ CA25R\&re $=0 \& e e=0$; DATABASE OF

STATE INCENTIVES FOR RENEWABLES AND EFFICIENCY, NEVADA: INCENTIVES/POLICIES FOR

RENEWABLES \& EFFICIENCY, NEVADA: INCENTIVES/POLICIES FOR RENEWABLES \& EFFICIENCY,

RENEWABLES PORTFOLIO STANDARD (JUNE 2012),

http://www.dsireusa.org/incentives/incentive.cfm?Incentive Code $=\mathrm{NV} 01 \mathrm{R} \& \mathrm{re}=0 \& \mathrm{ee}=0$ (summarizing

RPSs for Arizona, California, and Nevada).

${ }^{22}$ Glennon \& Reeves, supra note 22, at $107-108$.

${ }^{23}$ Telephone Interview with Roger Johnson, Deputy Director for CEC Siting, Transmission, and

Environmental Protection Division, Eileen Allen, CEC Technical Advisor for Siting, Matt Layton,

Supervising Mechanical Engineer, CEC Siting, Transmission and Environmental Protection Division,

Paul Marshall, Senior Engineering Geologist, CEC Siting, Transmission and Environmental Protection

Division, James A. Bartridge, Advisor to CEC Commissioner Carla Peterman (June 27, 2012) [hereinafter

CEC Staff Interview].

${ }^{24} \mathrm{Id}$.

${ }^{25} \mathrm{Id}$.

${ }^{26} \mathrm{Id}$.

${ }^{27}$ Glennon \& Reeves, supra note 22, at 93 n.7.

${ }^{28}$ CALIF. ENERGY COMMN., COMMISSION DECISION: GENESIS SOlAR ENERGY PROJECT, Docket No. 09-

AFC-8, Socioeconomics Table 1, (Sept. 2010), http://www.energy.ca.gov/2010publications/CEC-8002010-011/CEC-800-2010-011-CMF.PDF [hereinafter CEC COMM’N DECISION].

${ }^{29}$ For a complete list of renewable energy for all of the 50 states, please see the Database of State

Incentives for Renewables \& Efficiency at: http://www.dsireusa.org/.

${ }^{30}$ DATABASE OF STATE INCENTIVES FOR RENEWABLES \& EFFICIENCY, ARIZONA: RENEWABLE ENERGY

PRODUCTION TAX CREDIT (May 2012),

http://www.dsireusa.org/incentives/incentive.cfm? Incentive Code $=\mathrm{AZ448} \& \mathrm{re}=0$ \&ee $=0$.

${ }^{31}$ DATABASE OF STATE INCENTIVES FOR RENEWABLES \& EFFICIENCY, ARIZONA: NON-RESIDENTIAL

SOLAR \& WIND TAX CREDIT (April 2012),

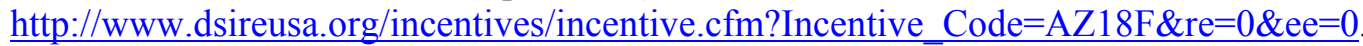

32 DATABASE OF STATE INCENTIVES FOR RENEWABLES \& EFFICIENCY, ARIZONA: PROPERTY TAX

ASSESSMENT FOR RENEWABLE ENERGY EQUIPMENT (JULY 2012),

http://www.dsireusa.org/incentives/incentive.cfm?Incentive Code $=\mathrm{AZ} 18 \mathrm{~F} \& \mathrm{re}=0 \& \mathrm{ee}=0$.

${ }_{33}$ DATABASE OF STATE INCENTIVES FOR RENEWABLES \& EFFICIENCY, ARIZONA: SOLAR AND WIND

SALES TAX EXEMPTION (April 2012),

http://www.dsireusa.org/incentives/incentive.cfm? Incentive Code $=$ AZ08F\&re $=0 \&$ ee $=0$.

${ }^{34}$ DATABASE OF STATE INCENTIVES FOR RENEWABLES \& EFFICIENCY, CALIFORNIA: PROPERTY TAX

EXCLUSION FOR SOLAR ENERGY SYSTEMS (AUG. 2012),

HTTP://WWW.DSIREUSA.ORG/INCENTIVES/INCENTIVE.CFM?INCENTIVE CODE=CA25F\&RE=0\&EE=0.

${ }^{35}$ DATABASE OF STATE INCENTIVES FOR RENEWABLES \& EFFICIENCY, CALIFORNIA: RENEWABLE

AUCTION MECHANISM (RAM) (June 2012),

http://www.dsireusa.org/incentives/incentive.cfm? Incentive Code $=\mathrm{CA} 25 \mathrm{~F} \& \mathrm{re}=0 \& \mathrm{ee}=0$.

${ }^{36}$ DATABASE OF STATE INCENTIVES FOR RENEWABLES \& EFFICIENCY, CALIFORNIA: CALIFORNIA SOLAR INITIATIVE (PV INCENTIVES) (December 2011),

http://www.dsireusa.org/incentives/incentive.cfm? Incentive Code $=$ CA25F\&re $=0 \& e e=0 ;$ Go SOLAR

CALIFORNIA, ABOUT THE CALIFORNIA SOLAR INITIATIVE (CSI),

http://www.gosolarcalifornia.ca.gov/about/csi.php.

${ }^{37}$ DATABASE OF STATE INCENTIVES FOR RENEWABLES \& EFFICIENCY, NEVADA: PORTFOLIO ENERGY CREDITS (June 2012),

http://www.dsireusa.org/incentives/incentive.cfm? Incentive Code $=\mathrm{NV} 09 \mathrm{~F} \& \mathrm{re}=0 \& \mathrm{ee}=0$. 
${ }^{38}$ DATABASE OF STATE INCENTIVES FOR RENEWABLES \& EFFICIENCY, NEVADA: REVOLVING LOAN PROGRAM (March 2012), http://www.dsireusa.org/incentives/incentive.cfm?Incentive Code $=$ NV39F\&re $=0 \&$ ee $=0$.

${ }^{39}$ DATABASE OF STATE INCENTIVES FOR RENEWABLES \& EFFICIENCY, NEVADA: RENEWABLE ENERGY SALES AND USE TAX ABATEMENT (JULY 2012), http://www.dsireusa.org/incentives/incentive.cfm?Incentive Code $=$ NV22F\&re $=0 \&$ ee $=0$.

${ }^{40}$ DATABASE OF STATE INCENTIVES FOR RENEWABLES \& EFFICIENCY, NEVADA: LARGE SCALE

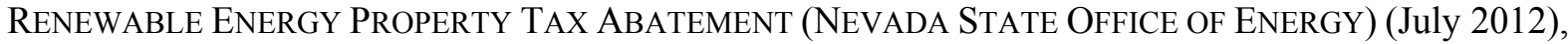
http://www.dsireusa.org/incentives/incentive.cfm?Incentive Code $=\mathrm{NV} 01 \mathrm{~F} \& \mathrm{re}=0 \& \mathrm{ee}=0$.

${ }^{41}$ Database of State Incentives for Renewables and Efficiency, Federal Incentives/Policies for Renewables \& Efficiency: Business Energy Investment Tax Credit (TIC) (Nov. 2011), http://www.dsireusa.org/incentives/incentive.cfm?Incentive Code=US02F\&re=1\&ee=1\&printable $=1$ (providing a comprehensive overview of federal renewable energy incentives and policies).

${ }^{42}$ Siobhan McIntyre \& Timothy P. Duane, Water, Work, Wildlife, and Wilderness: The Collaborative Federal Public Lands Planning Framework for Utility-Scale Solar Energy Development in the Desert Southwest, 40 ENVTL. L. 1093, 1100 (2011) (citing the Energy Policy Act of 2005, Pub. L. No. 109-58, 119 Stat. 594, 594).

${ }^{43}$ Id. (citing 42 U.S.C. $§ 16513$ ).

${ }^{44}$ Id. (citing Loan Guarantees for Projects that Employ Innovative Technologies, 72 Fed. Reg. 27,471, 27,476 (May 16, 2007) (codified at 10 C.F.R. pt. 609)).

${ }^{45} \mathrm{Id}$.

${ }^{46}$ Sarah Pizzo, When Saving the Environment Hurts the Environment: Balancing Solar Energy Development with Land and Wildlife Conservation in a Warming Climate, 22 Colo. J. INT'L L. \& POL'Y 123, 139 - 140 (Winter 2011) (quoting BUREAU OF LAND MGMT., U.S. DEP'T OF THE INTERIOR, InSTRUCTION MEMORANDUM No. 2007-097, SOlAR ENERGy DEVELOPMENT POLICY (2007)).

${ }^{47}$ BUREAU OF LAND MGMT., U.S. DEP'T OF THE INTERIOR, BLM FACT SHEET: RENEWABLE ENERGY AND THE BLM: SOLAR (Apr. 2014),

http://www.blm.gov/pgdata/etc/medialib/blm/wo/MINERALS_REALTY_AND_RESOURCE_PROTE CTION_/energy/solar_and_wind.Par.99571.File.dat/9-\%20Solar_04_2014.pdf

${ }^{48}$ Pizzo, supra note $4 \overline{8}$, at $142-143$ (quoting 43 U.S.C. $\S 1201(\bar{a})(8)$ ).

${ }^{49}$ BUREAU OF LAND MGMT., U.S. DEP'T OF THE INTERIOR, BLM FACT SHEET: RENEWABLE ENERGY AND THE BLM: SOLAR (July 2012),

${ }^{50}$ Robert L. Glicksman, Solar Energy Development on the Federal Public Lands: Environmental Tradeoffs on the Road to a Lower-carbon Future, 3 SAN DIEGO J. CLIMATE \& ENERGY L. 107, 130 (2011).

${ }^{51}$ McIntyre \& Duane, supra note 44, at 1112 (quoting 43 U.S.C. $\$ 1765$ (a)(iii) - (iv)).

${ }^{52}$ Id. at $1112-1113$ (citing 43 U.S.C. $§ 1701(\mathrm{a})(5)$ ).

${ }^{53}$ Pizzo, supra note 48 , at $142-146$

${ }^{54}$ Doug McMurdo, Solar Projects Take Home of Hoover Dam Back to Future, LAS VEGAS REVIEW JOURNAL (Feb. 6, 2012).

${ }^{55}$ Telephone interview with Kristin Mayes, Former Chairman of the Ariz. Corp. Comm'n (July 23, 2012) [hereinafter Mayes Interview] (stating that it may not "make sense" for Arizona to approve wet cooled CSP projects that will export energy when other states have taken steps to curtail such projects).

${ }^{56}$ Telephone interview with Christopher Harris, Acting Executive Director, Colorado River Board of California (July 31, 2012).

${ }^{57}$ Glicksman, supra note 52, at $129-130$.

${ }^{58} \mathrm{Id}$.

${ }^{59}$ McIntyre \& Duane, supra note 44 at 1133 - 1167 (discussing BLM collaboration with Arizona, California, and Nevada for fast-tracked solar projects).

${ }^{60} \mathrm{Id}$. at 1161 - 1162 (describing state-federal coordination on the Ivanpah CSP project in California). 
${ }^{61}$ Id. at $130-136$.

${ }^{62} \mathrm{Id}$. at $130-136$.

${ }^{63}$ U.S. Dep't of the Interior, News Release: Obama Administration Approves Roadmap for Utility-Scale Solar Energy Development on Public Lands (Oct. 12, 2012),

http://www.doi.gov/news/pressreleases/Obama-Administration-Approves-Roadmap-for-Utility-ScaleSolar-Energy-Development-on-Public-Lands.cfm\#; Bureau of Land Mgmt., Notice of Availability of the Final Programmatic Impact Statement for Solar Energy Development in Six Southwestern States, 77 Fed. Reg. 44,267, 44,268 (July 27, 2012) [hereinafter BLM PEIS Notice], http://solareis.anl.gov/documents/docs/NOA Final_Solar_PEIS.pdf.

${ }^{64}$ BUREAU OF LAND MGMT \& U.S. DEP'T OF ENERGY, FINAL PROGRAMMATIC IMPACT STATEMENT FOR SOlar ENERGY DeVElopment In SiX SOUTHWESTERn StATES, Appendix A, 1 (July 2012) [hereinafter BLM APPENDIX A], http://solareis.anl.gov/documents/index.cfm.

${ }^{65}$ U.S. Dep't of the Interior, News Release, Obama Administration Releases Roadmap for Solar Energy Development on Public Lands (July 24, 2012), http://www.doi.gov/news/pressreleases/ObamaAdministration-Releases-Roadmap-for-Solar-Energy-Development-on-Public-Lands.cfm.

${ }^{66}$ BLM PEIS Notice, supra note 65.

${ }^{67} \mathrm{Id}$.

${ }^{68}$ U.S. Dep't of the Interior, supra note 67.

${ }^{69}$ BLM PEIS Notice, supra note 65.

${ }^{70} \mathrm{Id}$.

${ }^{71}$ Phil Taylor, Amid Protests, BLM Could Finalize Solar Plan This Month, E\&E NEws PM (Sept. 6, 2012) (citing letter from Janine Blaelock, Director, Western Lands Project on behalf of Basin and Range Watch and Solar Done Right, to BLM Director (Aug. 24, 2012), http://www.eenews.net/assets/2012/09/05/document_gw_05.pdf; letter from Katherine Gensler, Solar Energy Industry Association Director of Regulatory Affairs, and Shannon Eddy, Executive Director, Large-scale Solar Association, to BLM Director (Aug. 27, 2012), http://www.eenews.net/assets/2012/09/06/document_pm_02.pdf; letter from Lisa T. Belenky, Center for Biological Diversity Senior Attorney, to BLM Director (Aug. 23, 2012), http://www.eenews.net/assets/2012/09/06/document pm 01.pdf; letter from Michael Connor, Western Watersheds Project California Director, to BLM Director (Aug. 27, 2012), http://www.eenews.net/assets/2012/09/06/document pm 03.pdf; letter from Jamie Rappaport Clark, Defenders of Wildlife President and CEO, to BLM Director (Aug. 27, 2012), http://www.eenews.net/assets/2012/09/06/document pm 04.pdf).

${ }^{72}$ Source of capital costs: E3. Additional information for calculating LCOE (O\&M costs, plant efficiency, capacity factor) is derived from E3 data. Fuel prices and other components are derived from the Energy Information Agency's Annual Energy Outlook 2012 (http://www.eia.gov/forecasts/aeo/). LCOE ranges result from the use of $3 \%$ and $10 \%$ discount rates.

${ }^{73}$ Sioshansi, R.; Denholm, P. (2010). The Value of Concentrating Solar Power and Thermal Energy Storage. NREL Report No. TP-6A20-45833. Golden, CO: National Renewable Energy Laboratory.

${ }^{74}$ Jorgenson, J.; Denholm, P.; Mehos, M.; Turchi, C. (2013). Estimating the Performance and Economic Value of Multiple Concentrating Solar Power Technologies in a Production Cost Model. . 38 pp.; NREL Report No. TP-6A20-58645.

${ }^{75}$ L. Stoddard, J. Abiecunas \& R. O'Connell, Economic, Energy, and Environmental Benefits of Concentrating Solar Power in California, NAT'L RENEWABLE ENERGY LAB. SUBCONTRACT REP., NREL/SR-550-39291, 5-10 (April 2006), http://www.nrel.gov/docs/fy06osti/39291.pdf.

${ }^{76}$ U.S. Energy Info. Admin., Projected Natural Gas Prices Depend on Shale Gas Resource Economics, TODAY IN ENERGY (Aug. 27, 2010) (describing the drop in natural gas prices), http://www.eia.gov/todayinenergy/detail.cfm?id=7710.

${ }^{77} I d$. 
${ }^{78}$ Tom Konrad, The Next Trend: Integrating PV with Solar Thermal, FORBES.COM (June 26, 2012)

[hereinafter, Konrad Next Trend], http://www.forbes.com/sites/tomkonrad/2012/06/26/the-next-trendintegrating-pv-with-solar-thermal/.

${ }^{79}$ Richard Swanson, Photovoltaics Power Up, 324 Science 891 (May 2009), http://phys.iit.edu/ segre/phys100/science 2009324 891.pdf; Konrad Next Trend, supra note 78; Stephen Lacey, Anatomy of a Solar PV System: How to Continue "Ferocious Cost Reductions" for Solar Electricity, THINKPROGRESS.ORG (July 6, 2011), http://thinkprogress.org/climate/2011/07/06/261550/solar-pv-system-cost-reductions/?mobile=nc (discussing falling PV costs).

${ }^{80}$ K. Branker, M.J.M. Pathak \& J.M. Pearce, A Review of Solar Photovoltaic Levelized Cost of Electricity, 15 RENEWABLE AND SUSTAINABLE ENERGY REVIEWS, 4470-4482 (Dec. 2011), http://www.sciencedirect.com/science/article/pii/S1364032111003492.

${ }^{81}$ Stephen Lacey, The World's Largest Planned Solar Plant Switching $500 \mathrm{MW}$ from Concentrated Solar Thermal to Photovoltaics, THINKPROGRESS.ORG (Aug. 18, 2011), http://thinkprogress.org/climate/2011/08/18/298913/the-worlds-largest-planned-solar-plant-switchingcsp-to-pv/.

${ }^{82}$ Reuters, Solar Thermal Plants Scrap Steam for Photovoltaic, CNET (July 1, 2011), http://news.cnet.com/8301-11128 3-20076065-54/solar-thermal-plants-scrap-steam-for-photovoltaic/.

${ }_{83}^{83}$. (quoting GTM Research analyst Brett Prior).

${ }^{84} \mathrm{Id}$.

${ }^{85}$ Lacey, supra note 82.

${ }^{86}$ Becky Beetz, Whole 1 GW Blythe Project to Convert to PV, PV Magazine (July 3, 2012), http://www.pv-magazine.com/news/details/beitrag/whole-1-gw-blythe-project-to-convert-topv 100007604/\#axzz26EU9FtWh.

${ }^{87}$ Katie Fehrenbacher, Solar Struggles: Stirling Energy Systems Files for Bankruptcy, WWW.GIGAOM.COM (Sept. 29, 2011), http://gigaom.com/cleantech/solar-struggles-stirling-energysystems-files-for-bankruptcy/.

${ }^{88}$ Turchi et al., supra note 13 .

${ }^{89}$ Tom Konrad, Cheap Photovoltaics are Eating Solar Thermal's Lunch, FORBES.COM, (Nov. 28, 2011), http://www.forbes.com/sites/tomkonrad/2011/11/28/cheap-photovoltaics-are-eating-solar-thermals-lunch/ [hereinafter Konrad Cheap Photovoltaics].

${ }^{90}$ Nathan Mee \& Marc L. Miller, Here Comes the Sun: Solar Power Parity with Fossil Fuels, 36 WM. \& MARY ENVTL. L. \& POL'Y REV. 119, 131 - 145 (Dec. 2011).

${ }^{91} I d$. at 134.

${ }^{92}$ Stoddard et al., supra note 76, at ES-1.

${ }^{93}$ Konrad Cheap Photovoltaics, supra note 89.

${ }^{94}$ PAUl DENHOLM \& MARK MEHOS, NAT'L RENEWABle ENERGy LAB, ENABLing GREATER PENETRATION OF SOlar POWER VIA THE USE OF CSP WITH THERMAL ENERGy STORAGE, TP-6A2052978, 1 (Nov. 2011), http://www.nrel.gov/docs/fy12osti/52978.pdf.

${ }_{95}$ Mee \& Miller, supra note 91 , at 133.

${ }^{96}$ Interagency Working Group on Social Cost of Carbon. 2013. Technical Update of the Social Cost of Carbon for Regulatory Impact Analysis under Executive Order 12866. May. United States Government. ${ }^{97} \mathrm{Id}$.

${ }^{98}$ ENVTL. LAW INST., ESTIMATING U.S. GOVERNMENT SUBSIDIES TO ENERGY SOURCES: 2002-2008, 3 (Sept. 2009), http://www.elistore.org/Data/products/d19 07.pdf. The report further notes that over half the subsidies for renewables ( $\$ 16.8$ billion) were attributable to corn-based ethanol. Of the fossil fuel subsidies, $\$ 70.2$ billion went to traditional sources such as oil and coal, while $\$ 2.3$ billion went to carbon capture and storage. $I d$. 
${ }^{99}$ Mee \& Miller, supra note 94, at 141 (discussing a carbon tax and other ways to increase the competitiveness of solar energy).

${ }^{100}$ INT'L ENERGY AGENCY, MEDIUM-TERM GAS MARKET REPORT 2012, (predicting that the U.S. will become a net exporter of gas and that that global demand for gas will rise at an annual growth rate of 2.4\%.), http://www.iea.org/Textbase/nptoc/MTGMR2012TOC.pdf.

${ }^{101}$ U.S. Energy Info. Admin, supra note 75.

102 JAMES A. HOLTKAMP \& MARK A. DAVIDSON, HOLLAND \& HART, TRANSMISSION SITING IN THE WESTERN UNITED STATES: OVERVIEW AND RECOMMENDATIONS PREPARED AS INFORMATION TO THE WESTERN INTERSTATE ENERGY BOARD, 5 (August 2009) (citing ENERGY INFORMATION ADMIN., U.S. DEP' T OF ENERGY, EleCtrical POWER ANNUAL REPORT WITH DATA FOR 2007, Table 3.2 (Jan. 21, 2009)), http://www.hollandhart.com/articles/Transmission_Siting_White Paper_Final.pdf.

${ }^{103} I d$. at $1-5$.

${ }^{104} I d$. at $6-9$

${ }^{105}$ Mayes Interview, supra note 57.

${ }^{106} I d$.

${ }^{107}$ Harris, supra note 58.

${ }^{108}$ BrightSource Energy, What is Ivanapah?, http://ivanpahsolar.com/about; Julie Cart, Saving Desert Tortoises Is a Costly Hurdle for Solar Projects, LOS ANGELES TIMES (March 4, 2012) (describing Ivanpah project)., http://articles.latimes.com/2012/mar/04/local/la-me-solar-tortoise-20120304 .

${ }_{109}$ Brightsource Energy, supra note 106; Cart, supra note 108.

${ }^{110}$ Brightsource Energy, supra note 106; Cart, supra note 108.

${ }^{111}$ Brightsource Energy, supra note 106; Cart, supra note 108; BUREAU OF LAND MGMT., DECISION: CACA 048668, CACA 049502, CACA 049503, CACA 049504 (April 15, 2011), http://www.westernwatersheds.org/ca/ivanpah/04-15-11-ISEGSTemporarySuspensionNotice.pdf (describing BLM's temporary stop-work order).

${ }^{112}$ BUREAU OF LAND MGMT., REVISED BIOLOGICAL ASSESSMENT FOR THE IVANPAH SOLAR ELECTRICT GENERATING SySTEM (IVANPAH SEGS) ProJeCt, 4-1 (April 19, 2011), http://www.westernwatersheds.org/ca/ivanpah/04-19-11-ISEGS-revised-BA.pdf.

${ }^{113} I d$. at , 4-2 and 4-3 (stating that 203 adult tortoises and 1,541 juveniles in the area immediately surrounding the project work area will be "harassed.").

${ }^{114}$ BrightSource Energy, Desert Tortoise Care at the Ivanpah Solar Project (March 6, 2012), (describing Ivanpah's desert tortoise mitigation efforts), http://ivanpahsolar.com/desert-tortoise-care-at-the-ivanpahsolar-project.

${ }^{115}$ Todd Woody, Sierra Club, NRDC Sue Feds to Stop Big California Solar Power Project, FORBES (MARCH 27, 2012), HTTP://WWW.FORBES.COM/SITES/TODDWOODY/2012/03/27/SIERRA-CLUB-NRDC-SUEFEDS-TO-STOP-BIG-CALIFORNIA-SOLAR-POWER-PROJECT/.

${ }^{116}$ Louis Sahagun, Discovery of Indian Artifacts Complicates Genesis Solar Project, LOS ANGELES TIMES (Apr. 24, 2012) (discussing concerns about the Genesis Solar Project's possible impacts on Native American cultural resources in California) (hereinafter Sahagun Artifacts], http://articles.latimes.com/2012/apr/24/local/la-me-solar-bones-20120424.

${ }^{117}$ Notwithstanding these requirements, it is important to note that most western states recognize instream uses as a beneficial use regardless of the traditional need for a diversion. Craig Bell \& Jeff Taylor, W. StATES WATER COUNCIL, WATER LAWS AND POLICIES FOR A SUSTAINABLE FUTURE: A WESTERN STATES' PERSPECTIVE, 176 - 177 (June 2008), http://www.westgov.org/wswc/laws\%20\&\%20policies\%20report $\% 20$ (final $\% 20$ with\%20cover).pdf (discussing how states have modified the prior appropriation doctrine to accommodate instream uses). Beneficial use also incorporates the concept that the use must be reasonable and without waste as traditionally measured by local custom and practice. Lawrence J. MacDonnell and Teresa A. Rice, 
Moving Agricultural Water to Cities: The Search for Smarter Approaches, 14 HaSTINGS W.-N.W. J. ENV. L. \& POL'Y 105, 120 (2008) (describing reasonable use in the West).

${ }^{118}$ BELL \& TAYLOR, supra note 117 , at 67.

${ }^{119} I d$. at 110.

${ }^{120}$ Abandonment occurs when a water right holder no longer uses the right and no longer intends to use it. In contrast, forfeiture does not require intent and results when a right holder loses his or her right after not using it beneficially for a specific period of time. Prescription basically refers to the adverse possession of water resources. $I d$. at 71 .

${ }^{121} \mathrm{Id}$. at $70-71,110$.

${ }^{122}$ ARIZ. REV. STAT. § 45-151 (A).

${ }^{123}$ ARIZ. DEP'T OF WATER RES., WATER MANAGEMENT REQUIREMENTS FOR SOLAR POWER PLANTS IN ARIZONA describing Arizona's water right permitting process for solar development), http://www.azwater.gov/azdwr/WaterManagement/documents/SolarPowerPlantsSummaryFINALPublic.p $\frac{\mathrm{df}}{124}$

${ }^{\frac{\mathrm{f}}{124}}$ Colorado River water delivered via the CAP canal, operated by the Central Arizona Water Conservation District.

${ }^{125}$ Id. See also ARIZ. REV. STAT. § 45-101(9) (stating that surface water consists of "all sources, flowing in streams, canyons, ravines or other natural channels, or in definite underground channels, whether perennial or intermittent, floodwater, wastewater or surplus water, and of lakes, ponds and springs on the surface.").

${ }^{126}$ ARIZ. REV. STAT. $\S 45-152(B)(2)$.

${ }^{127}$ Id. $\S 45-152(\mathrm{C})$.

${ }^{128} I d . \S 45-152(\mathrm{~B})(3)$.

${ }^{129} I d$. $\S 45-1201(1)$. This requirement does not apply to reservoirs owned, controlled, operated, maintained, or managed under the Bureau of Land Management Dam Safety program. Id. See also ARIZ. DEP'T OF WATER RES., supra note 123, at 6.

${ }^{130}$ Id. $\S 45-153(\mathrm{~A})$.

${ }^{131} I d . \S 45-162(\mathrm{~B})$.

${ }^{132} I d . \S 45-156(\mathrm{~A}),(\mathrm{B})$.

${ }^{133}$ ARIZ. DEP'T OF WATER RES., supra note 123, at 8. See also ARIZ. REV. STAT. $§ 45-172$.

${ }^{134} I d$.

${ }^{135}$ Id. See also ARIz. REV. StAT. § 45-172(A)(4), (5). See also ARIZ. REV. StAT. § 45-156(B) .

${ }^{136}$ Boulder Canyon Project Act., 43 U.S.C. $\$ 617$ et seq.

${ }^{137}$ BonNIE COLBY ET AL., UNIV. OF ARIZ., ARIZONA's WATER Future: CHALlENGES AND OPPORTUNITIES, 61 (2004), http://wrrc.arizona.edu/sites/wrrc.arizona.edu/files/publications/townhall/intro toc.pdf.

${ }^{138} I d$.

139 ARIZ. REV. STAT. $\S \$ 45-401$ to -703 .

${ }^{140}$ Id. $\S 45-411$.

${ }^{141}$ ARIZ. REV. STAT. § 45-561(12). "Safe yield" means "a groundwater management goal which attempts to achieve and thereafter maintain a long-term balance between the annual amount of groundwater withdrawn in an active management area and the annual amount of natural and artificial recharge in the active management area."

${ }^{142}$ Rita Pearson Maguire, Patching the Holes in the Bucket: Safe Yield and the Future of Water Management in Arizona, 49 ARIZ. L. REV. 361, 362 n.3 (2007).

${ }^{143}$ ARIZ. DEP'T OF WATER RES., supra note 123, at 9.

${ }^{144} I d$. at 8.

${ }^{145}$ ARIZ. REV. STAT. § 45-469. 
${ }^{146}$ Id. See also ARIZ. REV. StAT. $§ ~ 45-470,473$; ARIZ. DEP’ T. OF WATER RES., OVERVIEW OF THE ARIZONA GROUNDWATER MANAGEMENT CODE, 3, (describing Arizona groundwater permitting requirements within AMAs) [hereinafter ADWR Overview], http://www.azwater.gov/AzDWR/WaterManagement/documents/Groundwater_Code.pdf

${ }^{147} I d$. $\S 45-471$. See also ARIZ. DEP'T OF WATER RES, supra note 123, at 2.

${ }^{148}$ Id. § 45-515. See also ARIZ. DEP’T OF WATER RES., supra note 123, at 2.

${ }^{149}$ ARIZ. DEP'T OF WATER RES., supra note 123, at 3.

${ }^{150}$ Email from Michael Lacey, Ariz. Dep't of Water Res. Deputy Directory, to Nathan Bracken, WSWC Legal Counsel (Sept. 7, 2012) (on file with authors) (commenting on draft versions of this report and describing water right permitting for CSP in Arizona).

${ }^{151} I d$. $\S 45-596$.

${ }^{152} I d . \S 45-437(\mathrm{C})(1)$.

153 ARIZ. DeP' T OF WATER RES., ARIZONA WATER AtLas Volume 1, APPENDiX C: SUMMARY OF ARIZONA WATER LAW AND MANAGEMENT, 127 (Sept. 2010), http://www.adwr.state.az.us/AzDWR/StatewidePlanning/WaterAtlas/documents/appendix c.pdf; Tom Whitmer, Water Management in Arizona, 2 BACKYARDS AND BEYOND 5 (Spring 2008), http://cals.arizona.edu/backyards/archive/2008/08spring.pdf.

${ }^{154} I d . \S \S 45-594$ and 45-596. See also ARIZ. DEP'T OF WATER RES., supra note 123, at 3.

${ }^{32}$ ARIZ. REV. STAT. $\S \S 45-544$. See also ARIZ. DEP’T OF WATER RES., supra note 123, at 4.

${ }^{156}$ ARIZ. REV. STAT. § 45-551.

${ }^{157}$ Id. $\S \S 45-552,45-553,45-554,45-555$. ARIZ. DEP'T OF WATER RES., supra note 123, at 4.

${ }_{158}$ Arizona Public Service Co. v. Long, 160 Ariz. 429, 773 P.2d 988(1989)

${ }^{159}$ GOVt. ACCOUNTABILITy OfFICE, ENERGY-WATER NEXUS: IMPROVEMENTS TO FEDERAL WATER USE DATA WOULD INCREASE UNDERSTANDING OF TRENDS IN POWER PLANT WATER USE, REPORT TO THE Chairman, CommitTeE on SCIENCE AND TEChNOlogy, House OF RePRESENTATIVES, 59 (Oct. 2009), http://www.gao.gov/new.items/d1023.pdf.

${ }^{160}$ ARIZ. DEP'T OF WATER RES., supra note 123, at 5.

${ }^{161}$ GOVT. ACCOUNTABILITY OFFICE, supra note 159 , at 59.

162 ARIZ. REV. STAT. § 45-851.01.

${ }^{163}$ Id. $\S 45-852.01$.

${ }^{164}$ ARIZ. DEP'T OF WATER RES., supra note 123, at 5 (citing ARIZ. REV. STAT. $\S \S 45-834.01$, 45 802.01(22), 45-852.01(B)(1), 45-854.01(C)).

${ }^{165} \mathrm{Id}$.

${ }^{166}$ Lacey, supra note 150.

${ }^{167}$ GOVT. ACCOUNTABILITY OFFICE, supra note 159 , at 61.

${ }^{168}$ Ariz. Dep't of Envtl. Quality, Water Quality Division Permits: Arizona Pollutant Discharge Elimination System (AZPDES), http://www.azdeq.gov/environ/water/permits/azpdes.html.

${ }^{169}$ GOVT. ACCOUNTABILITY OFFICE, supra note 159 , at 61 , at $59-61$.

${ }^{170} \mathrm{Id}$. at 60 .

${ }^{171}$ ARIZ. REV. STAT. § 40-360.13.

${ }^{172} I d$.

${ }^{173} \mathrm{Id}$.

${ }^{174}$ Mayes Interview, supra note 57.

${ }^{175}$ Letter from Kristin Mayes, Chairman, Ariz. Corp. Comm'n, to Colleagues, Re: "Dry cooling and hybrid cooling technology use by concentrated solar projects in Arizona," 1 (Jan. 8, 2010), http://www.azcc.gov/commissioners/mayes/Letters.asp.

${ }^{176} I d$. at 2 . 
${ }^{177}$ Cynthia L. Schwartz, Concentrated Thermal Solar Power and the Value of Water for Electricity, in THE WATER-ENERGY NEXUS IN THE AMERICAN WeSt, 80 (Douglas S. Kenney \& Robert Wilkinson, eds., 2011).

${ }^{178}$ ARIZ. CORP. COMM'N, ORdER AMENDING DeCISION No. 71648, Docket No. L-00000NN-09-054100151, accessed at https://edocket.azcc.gov/.

${ }^{179}$ Ariz. Ctr. for Law in the Pub. Interest, Hualapai Valley Solar LLC, http://aclpi.org/case/hualapaivalley-solar-llc.

${ }^{180}$ BUREAU OF LAND MGMT., CALIFORNIA: WATER Rights FACT SHEET (2001), http://www.klamathbasincrisis.org/waterrights/blmwaterrightsfactsheet101609ca.htm.

${ }^{181} I d$.

${ }^{182} I d$. at $40-1$.

${ }^{183}$ GOVT. ACCOUNTABILITY OFFICE, supra note 159 , at 61.

${ }^{184}$ CAL. WATER. CODE $\S 13050(\mathrm{f})$.

${ }^{185}$ State Water Res. Control Bd., The Water Rights Process, http://www.waterboards.ca.gov/waterrights/board info/water rights process.shtml; U.S. FISH AND WILDLIFE SERVICE, SUMMARY OF CALIFORNIA WATER RIGHTS, 1-1 - 1-3 (summarizing surface water rights in California) http://www.fws.gov/cno/fisheries/docs/Section1SummaryofCAWaterRights.pdf. See also CAL. WATER. CODE $§ 1706$.

${ }^{186}$ STATE WATER RES. CONTROL BD., supra note 185.

${ }^{187}$ CAL. WATER. CODE $\S \S 1000$ et seq., 1701, 1735.

${ }^{188}$ Id. $\S 1810(\mathrm{~d})$.

${ }^{189}$ STATE WATER RES. CONTROL BD., supra note 185.

${ }^{190} \mathrm{Id}$.

${ }^{191}$ StATE WATER REs. CONTROL BD., FAQS: WHAT IS A RIPARIAN RIGHT?, http://www.waterboards.ca.gov/waterrights/board info/faqs.shtml\#toc178761088.

${ }^{192}$ CAL. WATER. CODE $\S 1200$.

${ }^{193}$ StATE WATER RES. CONTROL BD., Decision 1645, 7 (2002) (citing Decision 1639, 4 (1999)), http://www.swrcb.ca.gov/waterrights/board decisions/adopted orders/decisions/d1600 d1649/wrd1645.p df.

${ }^{194}$ U.S. FISH AND WILDLIFE SERVICE, supra note 185 at 1-2.

${ }^{195}$ STATE WATER RES. CONTROL BD., supra note 185.

${ }^{196}$ U.S. FISH AND WILDLIFE SERVICE, supra note 185 at 1-1 - 1-2.

${ }^{197}$ STATE WATER RES. CONTROL BD., supra note 185; U.S. FISH AND WILDLIFE SERVICE, supra note 185 at $1-1-1-2$, http://www.waterboards.ca.gov/waterrights/board_info/water_rights process.shtml.

198 CAL. WATER CODE $\S 462$.

${ }^{199}$ Anyone who recycles or proposes to recycle water, and who uses or proposes to use recycled water, must file a report with the appropriate Regional Water Board. CAL. WATER CODE $\S 13522.5$. If a Regional Water Board determines that it is necessary to protect public health, safety, or welfare, it may prescribe water recycling requirements where recycled water is used or proposed to be used. CAL. WATER CODE $\S 13523$.

${ }^{200}$ Nathan Bracken, Water Reuse in the West: State Programs and Institutional Issues, 18 HASTINGS W.-NW J. ENVTL. L. \& POL'Y 451 (June 2012).

20133 Cal.3d 419, 445 (1983).

${ }^{202} I d$. at $446-447$.

${ }^{203}$ Id. at 452. See also Sandi Zellmer and Jessica Harder, Unbundling Property in Water, 59 ALA L. REVIEW 679, 696 (2007-2008) (summarizing the case's holding).

${ }^{204}$ GOVT. ACCOUNTABILITY OFFICE, supra note 159 at 65; STATE WATER RES. CONTROL BD., NATIONAL Pollutant Discharge Elimination System: THE Role of THE STATE AND REgIONAL WATER 
QUALITY CONTROL BOARDS (describing NPDES permitting in California)

http://www.waterboards.ca.gov/water issues/programs/npdes/.

${ }^{205} I d$.

${ }^{206}$ GOVT. ACCOUNTABILITY OfFICE, supra note 159 at 63 - 65; CHRISTINA TAGUE \& JEFF DOZIER, DONALD BREN SCHOOL OF ENVTL. SCIENCE AND MGMT, UnIV. OF CAL., SANTA BARBARA,SOlaR Power TeChNOlogy SElection: Multiple ResourCe ECONOMics AND Policy, 10 - 11 (Sept. 2010) (discussing CEC's approval process), http://fiesta.bren.ucsb.edu/ solar/Documents/Group\%20Project\%20Proposal.pdf.

${ }^{207}$ Tague \& Dozier, supra note 203, at $10-11$.

${ }^{208} I d$.

${ }^{209} \mathrm{Id}$.

${ }^{210} \mathrm{Id}$.

${ }^{211}$ CAL. ENERgy COMM'N., Site CERTIFICATION Process GENERAL OVERVIEW, http://www.energy.ca.gov/public adviser/site certification process.html.

${ }^{212} I d$.

${ }^{213} I d$.

${ }^{214}$ Id. See also Tague \& Dozier, supra note 203, at 12.

${ }^{215} \mathrm{Id}$.

${ }^{216} I d$.

${ }^{217} I d$.

${ }^{218}$ GOVT. ACCOUNTABILITY OfFICE, supra note 159 at 63 - 65. The CEC's analysis for CEQA and other Laws, Ordinances, Regulations, and Standards (LORS) is not limited to water used only for cooling (email from Jim Bartridge, Advisor to CEC Commissioner Carla Peterman, to Nathan Bracken, WSWC Legal Counsel (Aug. 27, 2012) (commenting on CEC permitting process).

${ }^{219} I d$. at 64.

${ }^{220} \mathrm{Id}$.

${ }^{221} I d$.

${ }^{222}$ Memorandum of Understanding Between the U.S. Dep't of the Interior, Bureau of Land Mgmt., California Desert Dist. and the Calif. Energy Comm'n. Staff: Concerning Joint Environmental Review for Solar Thermal Power Plant Projects (2007), http://www.energy.ca.gov/siting/solar/BLM_CEC MOU.PDF. See also Tague \&Dozier, supra note 203, at 11 (describing memorandum of understanding between CEC and BLM).

${ }^{223}$ StATE WATER Res. CONTROL BD., WATER QuAlity CONTROL POLICY ON THE USE AND DisPosal OF INLAND WATERS USED FOR POWERPLANT COOLING, RESOLUTION NO. 75-58, 7 (1975), http://www.waterboards.ca.gov/board decisions/adopted_orders/resolutions/1975/rs75 058.pdf. See also CALIF. ENERGY COMM’N, REVISED STAFF REPORT, Docket 09-AFC-8, C.9-88 (June 2010), http://www.energy.ca.gov/siting/solar/BLM CEC MOU.PDF, [hereinafter CEC GENESIS STAFF ASSESSMENT] (describing Resolution 75-58). Of further note,

${ }^{224}$ State Water Res. Control Bd., Cooling Water Intake Structures: Once -Through Cooling, http://www.swrcb.ca.gov/water_issues/programs/ocean/cwa316/.

${ }^{225} I d$.

${ }^{226}$ CALIF. ENERGy COMM’N, INTEGRATEd ENERGy POLICY REPORT, 41 (2003), http://www.energy.ca.gov/reports/100-03-019F.PDF.

${ }^{227}$ CEC GENESIS STAFF ASSESSMENT, supra note 220, at C.9-90.

${ }^{228}$ Id.; Renewable Energy Action Team Report, Best Management Practices and Guidance Manual: Desert Renewable Energy Project, 1 (Sept. 2010) (hereinafter REAT 2010 Report).

${ }^{229}$ CALIF. ENERGY COMM’N, INTERIM GUIDANCE FOR DESERT RENEWABLE ENERGY PROJECT DEVELOPMENT, 4 (Sept. 2009), http://www.energy.ca.gov/2009publications/CEC-700-2009-015/CEC700-2009-015-SD.PDF. 
${ }^{230} I d$.

${ }^{231}$ REAT 2010 Report, supra note 225, at 3.

${ }^{232} I d$.

${ }^{233}$ Memorandum of Understanding Between the State of California and the Department of the Interior on Renewable Energy (Oct. 12, 2009), http://www.doi.gov/documents/CAMOUsigned.pdf.

${ }^{234}$ Id. See also Salazar Plans to Expedite Renewables on California Desert,

WWW.BASINANDRANGEWATCH.ORG, http://www.basinandrangewatch.org/FastTrackRenewable.html (describing 2009 MOU).

${ }^{235}$ NeV. Div. OF WATER Res., Nevada Water LaW: AN OVERVIEW, http://water.nv.gov/waterrights/waterlaw/.

${ }^{236}$ NEV. REV. STAT. $§ 533.025$.

${ }^{237} I d$. $\S \S 533.030,534.020$.

${ }^{238}$ NeV. Div. OF WATER Res., NeVAda Water Law: The Role of THE State, http://water.nv.gov/waterrights/waterlaw/state role.cfm.

${ }^{239}$ GOVT. ACCOUNTABILITY OFFICE, supra note 159 at 35.

${ }^{240}$ NEV. REV. STAT. $§ \$ 533.370,533.4375$.

${ }^{241} I d$. $\S \S 532.010$ et seq.; 533.005 et seq.; 534.010 et seq.; 534A.010 et seq.; 535.005 et seq.; 536.010 et seq.; 537.010 et seq.; 538.010 et seq.; 540.011 et seq.; 543.010 et seq.; 544.010 et seq. (Nevada's water laws); Id. $\S 533.370$ (describing the processed used to approve or reject proposed transfers).

${ }^{242} I d . \S 533.340$.

${ }^{243} I d . \S 533.330$.

${ }^{244} I d . \S 533.360$

${ }^{245} I d . \S 533.365$.

${ }^{246} I d . \S 533.365(4)$.

${ }^{247} I d . \S 533.450$.

${ }^{248}$ NeV. Div. OF WATER Res., NeVAdA WATER LAW: WATER PERMits (describing Nevada water rights permitting process), http://water.nv.gov/waterrights/waterlaw/water permits.cfm.

${ }^{249}$ NEV. REV. STAT $§ 533.372$

${ }^{250} I d . \S 533.368$

${ }^{251}$ NEV. DiV. OF WATER RES., NEVADA WATER LAW: INTERBASIN TRANSFERS, http://water.nv.gov/waterrights/waterlaw/interbasin transfers.cfm.

${ }^{252}$ NEV. REV. STAT. $\$ 553.370$

${ }^{253} I d . \S 553.438$.

${ }^{254}$ Id. $\S 533.440(3)$.

${ }^{255} I d . \S 533.024(\mathrm{a})$

${ }^{256}$ NEV. ADMIN. CODE. §§ 445A.2762 - 445A.2771 (2011).

${ }^{257}$ Edison Electric Institute, EEI State Generation \& Transmission Siting Director, 81 - 82 (March 2012), http://www.eei.org/ourissues/electricitytransmission/documents/state generation transmission siting dir ectory.pdf; GOVT. ACCOUNTABILITY OFFICE, supra note 159 at 40 (describing the PUC's permitting process).

${ }^{258}$ NEV. REV. STAT. $\S \S 704.820-704.900$.

${ }^{259}$ GOVT. ACCOUNTABILITY OFFICE, supra note 159 at 40.

${ }^{260} I d$.

${ }^{261}$ NEV. REV. STAT. $§ 445 A .345$ (authorizing BWPC to administer water quality protection programs).

${ }^{262} I d . \S 445$ A.415.

${ }^{263}$ NeV. Div. of EnVtl. Protection - Bureau of WATER Pollution Control, Types of

DISCHARGE PERMITS ISSUED BY THE BWPC (describing BWPC permits),

http://ndep.nv.gov/bwpc/discharge.htm.

${ }^{264} I d$. 
${ }^{265}$ GOVT. ACCOUNTABILITY OfFICE, supra note 159 at 36 (describing Nevada State Engineer concerns over groundwater use for cooling purposes).

${ }^{266}$ Nevada State Engineer, Ruling No. 5008, 24 - 25, 33 (March 20, 2001), http://images.water.nv.gov/images/rulings/5008r.pdf.

${ }^{267}$ Nevada State Engineer, Ruling No. 5115, $24-27$ (April 18, 2002), http://images.water.nv.gov/images/rulings/5115r.pdf.

${ }^{268}$ Email from Jason King, Nevada State Engineer, to Nathan Bracken, WSWC Legal Counsel (Sept. 14, 2012) (on file with author). See also Memorandum from Jonathan B. Jarvis, Regional Director, Pacific West Region, U.S. National Park Service, to Amy Leuders, Acting State Director, Nevada Bureau of Land Management (Feb. 5, 2009) (stating that a Deputy State Engineer indicated that the rulings would help formulate future decisions regarding water rights for solar development at a Dec. 1, 2008 meeting with federal land management agencies), http://www.peer.org/docs/nps/09 2004 jarvis solar memo.pdf.

${ }^{269}$ This table is based in part on Table 4 in GOVT. ACCOUNTABILITY OFFICE, supra note 159 at 34.

${ }^{270}$ Office of Senator Jon Kyl, "Water Policy Considerations: Deploying Solar Power in the State of Arizona," 2 (May 2010), http://circleofblue.org/waternews/wp-content/uploads/2010/08/solar-water1.pdf.

${ }^{271}$ NiCOLE T. CARTER \& RICHARD J. CAMPBELL, CONG. RESEARCH SERV., ISSUES OF CONCENTRATING SOLAR POWER (CSP) ELECTRICITY IN THE U.S. SOUTHWEST, CONGRESSIONAL RESEARCH SERVICE REPORT, R40631, at 1, 4 (June 2009).

${ }^{272} I d$. at 9.

${ }^{273} I d$.

${ }^{274}$ Cynthia L. Schwartz, Concentrated Thermal Solar Power and the Value of Water for Electricity, in THE WATER-ENERGY NEXUS IN THE AMERICAN WeSt, 79 (Douglas S. Kenney \& Robert Wilkinson, eds., 2011).

${ }^{275}$ Id. (citing Melissa Lamberton, et al., The Water-Energy Nexus, ARROYO, 7 (2010), http://ag.arizona.edu/azwater/files/Arroyo 2010.pdf).

${ }^{276}$ Office of Senator Jon Kyl, supra note 265, at 15.

${ }^{277}$ Martin Pasqualetti \& Scott Kelley, Arizona Water Institute, The Water Costs of Electricity in Arizona, at 2, http://www.circleofblue.org/waternews/wp-content/uploads/2010/08/AZ-Solar-Water-Fact-Sheet.pdf ${ }^{278} I d$.

${ }^{279}$ Office of Senator Jon Kyl, supra note 267, at 17; Jennifer Robison, Nevada Groups Compete to Export Renewable Energy, LAS VEGAS REVIEW-JOURNAL (Aug. 18, 2011) (explaining efforts to export renewable energy from Arizona and Nevada to California), http://www.lvrj.com/business/nevada-groupscompete-to-export-renewable-energy-128045563.html.

${ }^{280}$ Id.at 18; Mayes Interview, supra note 57.

${ }^{281}$ Cal. Energy Comm'n comments to Nathan Bracken, Ass't Director and General Counsel, W. States Water Council (June 5, 2014) (on file with authors).

282 Jarvis, supra note 263.

${ }^{283}$ Nevada State Engineer, Ruling No. 5750, 19 (July 16, 2007), http://images.water.nv.gov/images/rulings/5750r.pdf.

${ }^{284}$ Jarvis, supra note 265 (citing Nevada State Engineer, Order No. 1197, (Nov. 4, 2008), http://images.water.nv.gov/images/orders/1197o.pdf).

${ }^{285} \mathrm{Id}$.

${ }^{286}$ H. David Gold \& Jason Bass, Symposium on The Water-Energy Conundrum: Water Constraints on New Energy Development in the Southwest, 50 Nat. Resources J. 563, 580 (Fall 2010).

${ }^{287}$ Carter \& Campbell, supra note 268 at 12.

${ }^{288}$ Glicksman, supra note 52, at 116.

${ }^{289}$ Cal. Energy Comm'n comments to Nathan Bracken, Ass't Director and General Counsel, W. States Water Council (June 5, 2014) (on file with authors). 
${ }^{290} I d$. at 115 .

${ }^{291}$ Jarvis, supra note 263.

${ }^{292} I d$. at 6.

${ }^{293}$ CEC Staff Interview, supra note 25; Mayes Interview, supra note 57.

${ }^{294}$ GOVT. ACCOUNTABILITY OFFICE, supra note 159 at 65.

${ }^{295} \mathrm{Id}$. at 61. Mayes Interview, supra note 57 (discussing outlook for wet cooled CSP plants in Arizona).

${ }^{296}$ Glicksman, supra note 52 at 130.

${ }^{297} I d$.

${ }^{298}$ U.S. DEP'T OF THE INTERIOR, BUREAU OF LAND MGMT., RECORD OF DECISION, AMARGOSA FARM RD. SOLAR ENERGY PROJECT, 8 - 10 (2010),

http://www.blm.gov/pgdata/etc/medialib/blm/nv/field offices/las vegas field office/energy/solar millen nium -

/Amargosa_Farm_Road_ROD.Par.31331.File.dat/Amargosa\%20Farm\%20Road\%20ROD\%20signed.pdf. ${ }^{299} I d$.

${ }^{300}$ Carolyn Campbell, Amargosa Farm Road Switches from CSP to PV, GREENTECHMEDIA.COM (Oct. 12, 2011), http://www.greentechmedia.com/articles/read/Amargosa-Farm-Road-Switches-From-CSP-to-PV/.

${ }^{301}$ Glicksman, supra note 52, at 130.

${ }^{302} I d$.

${ }^{303}$ BLM APPENDIX A, supra note 66 at A-22 -29.

${ }^{304}$ Id at A-23.

${ }^{305} \mathrm{Id}$. at $\mathrm{A}-25$.

${ }^{306} I d$.

${ }^{307}$ Dan Sampson, Think Water When Designing CSP Plants, POWER, 3 (May 2012), http://www.powermag.com/water/Think-Water-When-Designing-CSP-Plants_4600_p4.html.

${ }^{308} I d$. at $144-150$.

${ }^{309} I d$. at $150-160$.

${ }^{310}$ Jarvis, supra note 265.

31143 U.S.C. 12A (requiring that water users cannot receive delivery of water from Lake Mead or use such water without a valid contract between the Secretary of the Interior).

312547 U.S. 150, 153 (2006) (stating that the consumptive use of water "includes all consumptive uses of water of the mainstream, including water drawn from the mainstream by underground pumping").

${ }^{313}$ STEPHANIE M. Wiele, STANLEY A. LEAKE, SANDRA J. OWEN-JOYCE \& EMMET H. MCGUIRE, U.S. GEOLOGICAL SURVEY SCIENTIFIC INVESTIGATIONS REPORT 2008-5113, UPDATE ON THE ACCOUNTING SURFACE AlONG THE LOWER COLORADO RIVER, 1 (2009), http://pubs.usgs.gov/sir/2008/5113/.

${ }^{314}$ Letter from Gerald R. Zimmerman, Acting Executive Director, Colo. River Bd. of Cal., to Mike Monasmith, Project Manager, Siting, Transmission and Environmental Protection Div., Cal. Energy Comm'n (July 2, 2010) (on file with author).

${ }^{315}$ Harris, supra note 59.

${ }^{316}$ Letter from Lori Gray-Lee, U.S. Bureau of Reclamation Regional Director, to Rachel E. Koss, Attorney, Adams, Broadwell, Joseph \& Cardoza (Dec. 14, 2010) (discussing proposed groundwater use of the Genesis Solar project in California), http://www.energy.ca.gov/sitingcases/genesis solar/documents/others/2010-1214 Bureau of Reclamation Response Letter TN-59321.pdf .

${ }^{317}$ Zimmerman, supra note 309

${ }^{318}$ Id. See also Stephen Weile et al., U.S. GeOlogical SuRVEY, UPDATE ON THE AcCOUNTING SuRface ALONG THE LOWER COLORADO RIVER (2009) (describing the accounting surface methodology), http://pubs.usgs.gov/sir/2008/5113/.

${ }^{319}$ Zimmerman, supra note 309.

${ }^{320} \mathrm{Id}$. (stating that the methodology "continues to be the primary tool Reclamation utilizes to 
determine if the use of a well does, or does not, result in a consumptive use of mainstream water from the lower Colorado River.")

${ }^{321}$ Bureau of Land Mgmt, Record of Decision for the Genesis Solar Energy Project, 13 (Nov. 2010) [hereinafter BLM Record of Decision] (stating, "The BLM has thoroughly reviewed the regulatory framework regarding the use of the accounting surface methodology of determining impacts to the Colorado River and determined that no formal regulation exists that requires... an allocation at this time."),

http://www.blm.gov/pgdata/etc/medialib/blm/ca/pdf/palmsprings/genesis.Par.95255.File.dat/Genesis\%20 ROD.pdf.

${ }^{322}$ Stoddard et al., supra 76, at 1 .

See also Nathan Mee \& Marc L. Miller, Here Comes the Sun: Solar Power Parity with Fossil Fuels, 36 WM. \& MARY ENVTL. L. \& POL'Y REV. 119, 131 (Dec. 2011) (citing statistics from the Department of Energy that show that solar electric power costs between twelve and fourteen cents per $\mathrm{kWh}$, compared to two to three cents per $\mathrm{kWh}$ for coal).

${ }^{323}$ U.S. DEP'T OF ENERGY, REPORT TO CONGRESS, CONCENTRATING SOLAR POWER COMMERCIAL APPLICATION STUDY: REDUCING WATER CONSUMPTION OF CONCENTRATING SOLAR POWER ELECTRICITY GENERATION, 13-14 [hereinafter U.S. Dep't of Energy Report to Congress], http://www1.eere.energy.gov/solar/pdfs/csp water study.pdf.

${ }_{324}^{324}$.

${ }^{325} \mathrm{Id}$. at 5 .

${ }^{326} I d$. at 14.

${ }^{327} \mathrm{Id}$.

${ }^{328} I d$.

${ }^{329} \mathrm{Id}$.

${ }^{330}$ Id.; Carter \& Campbell, supra note 268, at 3.

${ }^{331}$ U.S. Dep't of Energy Report to Congress, supra note 318, at 5.

${ }^{332} I d$.

${ }^{333}$ Hualapai Valley Solar, Project Status, http://hualapaivalleysolar.com/.

${ }^{334}$ James Chilton, P\&Z OKs Hualapai Valley Solar Plan, DAILY MINER (Sept. 18, 2009) (interviewing project developers regarding project's water usage), http://www.kingmandailyminer.com/main.asp?SectionID=1\&subsectionID=1\&articleID=33644.

${ }^{335} I d$.

${ }^{336}$ Suzanne Adams, No Deal Yet on Using Wastewater, DAILY MINER (Sept. 2, 2010) [hereinafter Adams No Deal], http://www.kingmandailyminer.com/main.asp?SectionID=1\&SubsectionID=797\&ArticleID=39813.

${ }^{337} I d$.

${ }^{338}$ Chilton, supra note 330.

${ }^{339} \mathrm{Id}$.

${ }^{340}$ Suzanne Adams, Red Lake Solar Project Stalled, DAILY MINER (May 24, 2011) [hereinafter Adams

Red Lake], http://www.kingmandailyminer.com/main.asp?SectionID=1\&subsectionID=798\&articleID=44743.

${ }^{341}$ In the Matter of the Application of Hualapai Valley Sollar LLC, Ariz. Corp. Comm'n, Reply in Support of Applicant's Application to Lift Stay, L-00000NN-09-0541-00151, 10 - 11, http://edocket.azcc.gov/.

${ }^{342}$ Letter from Christopher P. Durkin, President, Kingman Downtown Merchants' Ass'n, to Ariz. Corp. Comm'n, (April 1, 2010) (on file with author); Letter from Keith Walker, City Councilman, City of Kingman, to Ariz. Corp. Comm'n. (March 29, 2010) (on file with author); Letter from Lola Franklin, Chief Executive Officer, Kingman/Golden Valley Association of Realtors, to Ariz. Corp. Comm'n. (March 30, 2010) (on file with author) (expressing support for Hualapai Solar Project). 
${ }^{343}$ In the Matter of the Application of Hualapai Valley Sollar LLC, Ariz. Corp. Comm'n, Decision No. 71648, Docket No. L-00000NN-09-0541-00151, 5, 10 (Nov. 1, 2010), http://edocket.azcc.gov/.

${ }^{344}$ In the Matter of the Application of Hualapai Valley Sollar LLC, Ariz. Corp. Comm'n, Intervenor Bensusan's Response to Application to Lift Stay, L-00000NN-09-0541-00151, 10 - 11, http://edocket.azcc.gov/.

${ }^{345}$ In the Matter of the Application of Hualapai Valley Sollar LLC, Ariz. Corp. Comm'n, Reply in Support of Applicant's Application to Lift Stay, L-00000NN-09-0541-00151, 10 - 11, http://edocket.azcc.gov/.

${ }^{346} I d$. at 10.

${ }^{347}$ In the Matter of the Application of Hualapai Valley Sollar LLC, Ariz. Corp. Comm'n, Decision No. 71957, Order Amending Decision No. 71648, 3 (Nov. 1, 2010), http://edocket.azcc.gov/.

${ }^{348} \mathrm{Id}$. at 2.

${ }^{349} I d$.

${ }^{350}$ Suzanne Adams, Hualapai Must Be Dry to Fly, DAILY MiNER (Oct. 21. 2010), $\mathrm{http}$ ://www.kingmandailyminer.com/main.asp?SectionID=1\&SubsectionID=1\&ArticleID=40780.

${ }^{351}$ Adams Red Lake, supra note 336.

${ }^{352}$ Adams No Deal, supra note 332.

${ }^{353}$ Adams Red Lake, supra note 336.

${ }^{354}$ CleanEnergy Action Project, Solana Generating Station Case Study, http://www.cleanenergyactionproject.com/CleanEnergyActionProject/CS.Solana_Generating_Station Energy Storage Case Study.html.

${ }^{355}$ News Release from Dep't of the Interior, Secretary Salazar Approves Seventh Large-Scale Solar Energy Project on U.S. Public Lands (Nov. 4, 2010), http://www.doi.gov/news/pressreleases/SecretarySalazar-Approves-Seventh-Large-Scale-Solar-Energy-Project-on-US-Public-Lands.cfm.

${ }^{356}$ CEC COMM'N DECISION, supra note 30, at Socioeconomics Table 1.

${ }^{357}$ CEC GENESIS STAFF ASSESSMENT, supra note 218, at C.9-91.

${ }^{358}$ Energy Res. Conservation and Development Comm'n of the State of Cal., Decision and Scoping Order, Application for Certification for the Genesis Solar Energy Project, Docket No. 09-AFC-8, 3 (Feb. 2, 2010), http://www.energy.ca.gov/sitingcases/genesis solar/notices/2010-02-

02 Decision Scoping Order.pdf (emphasis added).

${ }^{359}$ CEC GENESIS STAFF ASSESSMENT, supra note 220, at C.9-91.

${ }^{360} \mathrm{Id}$. at C.9-92.

${ }^{361}$ Bureau of Land Mgmnt., Record of Decision for the Genesis Solar Energy Project, 26, 43 (Nov. 2010), http://www.blm.gov/pgdata/etc/medialib/blm/ca/pdf/palmsprings/genesis.Par.95255.File.dat/Genesis\%20 ROD.pdf [hereinafter BLM Genesis Record of Decision].

${ }_{362}$ Id.; CEC GENESIS STAFF ASSESSMENT, supra note 220, at C.9-92.

${ }^{363}$ CEC COMM'N DECISION, supra note 28 at 14.

${ }^{364}$ BLM Genesis Record of Decision, supra note 316, at 26, 43.

${ }^{365}$ Zimmerman, supra note 306.

${ }^{366}$ CEC COMM'N DECISION, supra note 30, at Soil and Water $8-13$

${ }^{367} \mathrm{Id}$.

${ }^{368}$ Cal. Energy Comm'n comments to Nathan Bracken, Ass't Director and General Counsel, W. States Water Council (June 5, 2014) (on file with authors).

${ }^{369}$ BLM Genesis Record of Decision, supra note 316, at 13.

${ }^{370}$ Cal. Unions for Reliable Energy et, al v. U.S. Dep't of the Interior, U.S. Dist. Court for the Central Dist. of Cal., Plaintiffs' Complaint for Declaratory and Injunctive Relief, CV 10-09932 (Dec. 27, 2010), http://www.courthousenews.com/2011/01/03/SolarWater.pdf. See also Robert Kahn, Enviros Throw Another Wrench into Solar Energy from Desert, COURTHOUSE NEWS SERVICE (Jan. 3, 2011), 
http://www.courthousenews.com/2011/01/03/33008.htm; Chris Meehan, BLM Sued by Unions over Genesis Solar Project Approval, WWW.CLEANENERGYAUTHORITY.COM,

http://www.cleanenergyauthority.com/solar-energy-news/blm-sued-by-unions-over-genesis-solar-project010711/ (describing CURE's lawsuit).

${ }^{371}$ Cal. Unions for Reliable Energy et, al v. U.S. Dep't of the Interior, supra note 366.

${ }^{372} I d$. at 11.

${ }^{373}$ Id. at $6,17$.

${ }^{374}$ Mala Subramanian, California District Court Grants Motion to Dismiss Claim Involving Colorado River Water Against Development of Solar Energy Plant for Lack of Standing, 16 W.WATER L. \& POL'Y REP. 2, 52 - 54 (Dec. 2011) (describing the district court's dismissal of CURE's lawsuit).

${ }^{375}$ Los Angeles Time Editorial, Solar Standoff in the Mojave, Los Angeles Times (May 1, 2012), http://articles.latimes.com/2012/may/01/opinion/la-ed-solar-desert-20120501; Sahagun Indian Artifacts, supra note 116; Louis Sahagun, Problems Cast Shadows of Doubt on Solar Project, Los Angeles Times (Feb. 11, 2012), [hereinafter Sahagun Problems Cast Shadows] (discussing non water-related concerns associated with the Genesis project), http://articles.latimes.com/2012/feb/11/local/la-me-solar-foxes$\frac{20120211 .}{376}$.

${ }^{376}$ Los Angeles Times Editorial, supra note 371; and Sahagun Problems Cast Shadows, supra note 116.

${ }^{377}$ Letter from Eldred Enas, Chairman, Colo. River Indian Tribes, to John Kalish, Field Office Manager, Bureau of Lang Mgmt - S. Coast Field Office, 6-7 (Jan. 19, 2002), http://www.critnsn.gov/crit contents/news/L_Kalish\%20GSEP(2) 01262012.pdf.

${ }^{378}$ Email from James Bartridge, Advisor to CEC Commissioner Carla Peterman, to Nathan Bracken, WSWC Legal Counsel (Aug. 27, 2012) (describing agreement between CRIT and NextEra) (on file with author).

${ }^{379}$ Sahagun Problems Cast Shadows, supra note 371.

${ }^{380}$ BASIN AND RANGE WATCh, NEVADA SOlAR ONE: ACCIONA GETs FEDERAL GRANT to EXPAND (Feb. 18, 2010), http://www.basinandrangewatch.org/SolarOneNV.html.

${ }^{381} I d$.

${ }^{382}$ BASIN AND RANGE WATCH, supra note 376.

${ }^{383}$ Staff report from Vicki G. Mayes, Boulder City Manager, to Boulder City Mayor and City Council (April 19, 2007) (describing city's water service agreement with Nevada Solar One) $1-2$ (on file with author).

${ }^{384}$ Staff report from Scott P. Hansen, Boulder City Director of Public Works, to Vickie G. Mayes, Boulder City Manager , 1 - 4 (April 10, 2012) (discussing possible agreement between Boulder City and Nevada Solar One over amendments to the project's water service agreement) (on file with author). ${ }^{385} I d$.

${ }^{386}$ Staff report from Scott P. Hansen, Boulder City Director of Public Works, to Vickie G. Mayes, Boulder City Manager , 36 - 39 (July 10, 2012) (discussing possible agreement between Boulder City and Nevada Solar One over amendments to the project's water service agreement) (on file with author). ${ }^{387} I$. .

${ }^{388}$ McMurdo, supra note 56.

${ }^{389} \mathrm{Id}$.

${ }^{390} \mathrm{Id}$.

${ }^{391}$ Email from Scott Hansen, Boulder City Public Works Director, to Nathan Bracken, WSWC Legal Counsel (Aug. 27, 2012) (describing Boulder City's perspective regarding project's water use and projected water demands).

${ }^{392}$ UNIV. OF MICH. SCHOOL OF NATURAL RES. AND ENVIRONMENT, RENEWABLE ENERGY IN THE

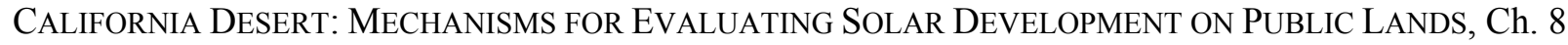
Socioeconomic Impacts, 15 (2010) (discussing a case study of the fiscal impacts of the Nevada Solar One project), 
http://webservices.itcs.umich.edu/drupal/recd/sites/webservices.itcs.umich.edu.drupal.recd/files/Chapter\% 208\%20Socioeconomic\%20Impact $\% 20$ Analysis_ 0.pdf.

${ }^{393} I d$.

${ }^{394}$ McMurdo, supra note 56.

${ }^{395}$ Roger Tobler, Mayor, Boulder City, Nev., State of the City Address (Jan. 26, 2012), http://bouldercityreview.com/news/text-of-the-mayors-state-of-the-city-address-on-jan-26/. ${ }^{396} I d$.

${ }^{397}$ UNIV. OF MiCH. SCHOOL OF NATURAL RES. AND ENVIRONMENT, supra note 389, at 12.

${ }^{398} I d$. at $15-16$.

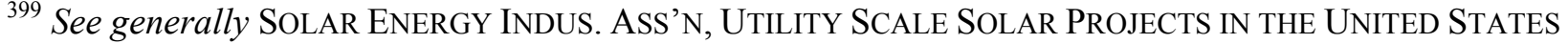
OPERATING, UNDER CONSTRUCTION, OR UNDER DEVELOPMENT (August 15, 2014), http://www.seia.org/sites/default/files/resources/PUBLIC\%20Major\%20Projects\%20List\%202014-819.pdf; Nat'1 Renewable Energy Lab., Concentrating Solar Power Projects, http://www.nrel.gov/csp/solarpaces/ (describing solar energy development in the U.S.).

${ }^{400} I d$. The SEIA data classifies the $250 \mathrm{MW}$ Tenaska Imperial Solar Energy Center West CPV project as PV technology. This table includes the Tenaska project within the CSP category, which accounts for the difference between the SEIA estimates for PV capacity and the estimates in this table.

${ }^{401} I d$.

${ }^{402} I d$.

${ }^{403} I d$.

${ }^{404} I d$. 